\title{
Anatomy and phylogenetic relationships of a new catfish species from northeastern Argentina with comments on the phylogenetic relationships of the genus Rhamdella Eigenmann and Eigenmann 1888 (Siluriformes, Heptapteridae)
}

\author{
FLÁVIO A. BOCKMANN ${ }^{1} \&$ AMALIA M. MIQUELARENA ${ }^{2}$ \\ ${ }^{1}$ Laboratório de Ictiologia de Ribeirão Preto (LIRP), Departamento de Biologia, FFCLRP, Universidade de São Paulo, Av. dos Ban- \\ deirantes 3900, 14040-901, Ribeirão Preto, SP, Brazil.E-mail: fabockmann@ffclrp.usp.br \\ ${ }^{2}$ Museo de La Plata (UNLP) and Instituto de Limnología "Dr. Raúl A. Ringuelet" (UNLP-CONICET), Paseo del Bosque s/n. 1900, La \\ Plata, Argentina.E-mail: miquelar@museo.fcnym.unlp.edu.ar
}

\section{Table of contents}

Abstract
Introduction
Material and methods
Rhamdella cainguae new species.
Description of skeleton and laterosensory system in Rhamdella cainguae
Acknowlts and discussion
Literature cited
Appendix

\begin{abstract}
Rhamdella cainguae, a new species of the family Heptapteridae is described from the Arroyo Cuña-Pirú, a tributary of the Río Paraná, in the subtropical forest of Misiones, northeastern Argentina. The presence of a large differentiated ovoid area on the supraorbital laterosensory canal along the frontal-sphenotic boundary, delimited by the slender dorsal walls of the bones, and with no foramen for a laterosensory branch, is an autapomorphy for $R$. cainguae. A detailed description of the skeleton and laterosensory system of $R$. cainguae is provided. The genus Rhamdella is rediagnosed on the basis of three autapomorphies: a very large opening in the frontal for the exit of the s6 (epiphyseal) branch of the supraorbital laterosensory canal (reversed in R. rusbyi), a large optic foramen, and a dark stripe along the lateral surface of the body (reversed in R. rusbyi). Rhamdella is considered to be the sister group of a large heptapterid clade composed of the Nemuroglanis sub-clade plus the genera Brachyglanis, Gladioglanis, Leptorhamdia, and Myoglanis. Rhamdella is herein restricted to five valid species: $R$. aymarae, $R$. cainguae, $R$. eriarcha, $R$. longiuscula, and $R$. rusbyi. A sister group relationship between $R$. aymarae and $R$. rusbyi is supported by three synapomorphies. Rhamdella cainguae shares 12 apomorphic features with $R$. eriarcha and $R$. longiuscula.
\end{abstract}

Key words: biogeography, South America, taxonomy, Teleostei 


\section{Introduction}

Rhamdella was first proposed by Eigenmann and Eigenmann (1888) as a subgenus of Rhamdia Bleeker, 1858, from which it was distinguished by having a cranial fontanel extending to the base of the supraoccipital, as opposed to having this fontanel not continuing behind the eye (Eigenmann and Eigenmann 1888). These authors designated Rhamdia eriarcha Eigenmann and Eigenmann (1888) as its type species, with a type locality of "Rio Grande do Sul" (=State of Rio Grande do Sul, Brazil). In 1890, Eigenmann and Eigenmann, in an identification key to the genera of the subfamily Pimelodinae, ranked Rhamdella as a genus, and added to its diagnosis the following characters: dorsal and pectoral fins with strong spines, pelvic fins placed below or behind the dorsal fin, and orbit with a free margin. However, none of these features, even in combination, are exclusive to Rhamdella. Subsequent authors, in describing or assigning species to Rhamdella, dismissed that diagnosis and failed to propose any alternative. Even Eigenmann and Eigenmann (1890) did not follow their own earlier Rhamdella diagnosis while transferring several species of Rhamdia to Rhamdella. Different species compositions for Rhamdella have been proposed by various authors (Gosline 1945; Burgess 1989) but none of those provided an unambiguous diagnosis of this genus. The poorly-defined limits of Rhamdella resulted in 37 nominal species being assigned to this genus since its description, making it the third most speciose genus in the family Heptapteridae, after Rhamdia and Pimelodella.

Rhamdella has been assigned to a monophyletic group currently known as family Heptapteridae (Lundberg and McDade 1986). When first described, Rhamdella was assigned to the then broadly inclusive family Siluridae (Eigenmann and Eigenmann 1888). Soon thereafter, Eigenmann and Eigenmann (1890) using the catfish classification of Günther (1864) as modified by Gill (1872), assigned Rhamdella to the silurid subfamily Pimelodinae. Eigenmann (1910) considered Rhamdella and Rhamdia distinct from each other, but met difficulties in discriminating which species belonged to each genus. The Pimelodinae was raised to family rank by Regan (1911) and Rhamdella has long been maintained in that family. Gosline (1945) included Rhamdella in the pimelodid subfamily Pimelodinae.

In this paper we describe a new heptapterid catfish species from Arroyo Cuña-Pirú, a tributary of the Río Paraná, in the subtropical forest of Misiones, northeastern Argentina. According to the ichthyogeographical scheme proposed by Ringuelet (1975), the study area belongs to the Paranoplatensean province (within the Paranensean dominion of the Brazilian subregion). The overall external morphology of this species would place it in Rhamdella according to current diagnosis of the genus (Burgess 1989; Lucena and Silva 1991). To test that assignment, we undertook a phylogenetic study to investigate the monophyly of Rhamdella and to evaluate its limits and composition.

Despite the highly diversified morphology of members of the family Heptapteridae, there are only two relatively complete anatomical studies on species of that group: Lundberg and McDade (1986) on Brachyrhamdia imitator Myers 1927, and Silfvergrip (1996) on Rhamdia quelen (Quoy and Gaimard 1824). Those descriptions did not, however, focus on phylogenetically relevant traits for the Heptapteridae and did not deal with the laterosensory system in detail. Those factors, plus the fact that Rhamdella displays numerous primitive features for the family, prompted us to provide a phylogenetically-oriented description of the skeleton and laterosensory system of the new species. Our descriptive accounts also aim at a unified nomenclature for the skeleton and laterosensory system in the family Heptapteridae, in order to facilitate future studies on this group.

\section{Material and methods}

Morphometric values were taken with digital calipers and are expressed to the nearest $0.1 \mathrm{~mm}$. All measurements were made point-to-point on left side of the specimen whenever possible. Terminology for measure- 
ments and skeleton followed Lundberg and McDade (1986) and Bockmann (1998), respectively. Measurements are presented as percentage of standard length (SL) or head length (HL), except for SL which is expressed in $\mathrm{mm}$. The bones traditionally named infraorbitals in siluriforms, of which the first is often named lacrimal (e.g. Lundberg and McDade 1986; Silfvergrip 1996), are herein called suborbitals, following Pollard (1892). According to Fink and Fink $(1981,1996)$ these bones in catfishes are reduced to their canalbearing portions. However, these elements in catfishes are homologous only to the canal-bearing ossified tubules, not to the plate-like bones which are usually called infraorbitals in other Teleostei. The plate-like bones, which may contain or not the canal-bearing ossified tubules, are the true infraorbital bones (Bockmann 1998). In other words, plate-like bones (the infraorbitals) and canal-bearing ossified tubules (the suborbitals) are independent structures which may co-occur or not. Justification for such a homology statement will be presented in greater detail elsewhere (Bockmann, in prep.). The only real infraorbital in catfishes is the antorbital, which is usually associated to two suborbital bones, the herein called antorbital tubule (at) and suborbital tubule 1 (st1) (Bockmann 1998).

Osteological preparations (indicated as C \& S) were prepared according to Dingerkus and Uhler (1977) and Taylor and Van Dyke (1981). Descriptions of the skeleton of the new species were based on three C \& S paratypes. Vertebral counts included all vertebrae including the first five vertebrae integrated to the Weberian complex and the compound caudal centrum (pu1+u1) which was counted as one element. Basal radials, branchiostegal rays, pleural ribs, and vertebrae were counted only on $\mathrm{C} \& \mathrm{~S}$ specimens. The number of specimens having a particular count is enclosed in parentheses. When meristics vary, the counts are separated in parentheses, and counts for the holotype are indicated by an asterisk. All anal-fin rays were counted individually, including the anterior splints and the two most posterior rays that insert on the same base. Terminology for cephalic laterosensory canals followed Northcutt (1989). Nomenclature and homologies for supraorbital and infraorbital laterosensory canal systems followed Arratia and Huaquin (1995). Anatomical illustrations were sketched using a Zeiss SV-6 stereomicroscope with a camera lucida attachment. In the drawings, bones are represented by stipples and cartilages by open circles.

Parsimony analysis was performed by Hennig86 computer program, version 1.5, through the exact algorithm implemented by the command "ie*" (Farris 1988), with the aid of its Windows shell Tree Gardener, version 2.1 (Ramos 1997), which was also used to edit the data matrix and map character states on the tree. Multistate characters were ordered according to similarity, in conformity with the sequence derived from morphoclines (Maslin 1952). In the case of ambiguous character-state distributions, ACCTRAN optimization was utilized in tracing character evolution. ACCTRAN maximizes homoplastic character changes represented as reversals rather than as parallelisms, thus minimizing falsification of initial hypotheses of primary homology (de Pinna 1991). Steps ("s"), consistency index ("ci"), and retention index ("ri") for each character are shown in parenthesis.

Abbreviations for institutions are: AMNH, American Museum of Natural History, New York; BMNH, Natural History Museum, London; CAS, California Academy of Sciences, San Francisco; FMNH, Field Museum of Natural History, Chicago; ILPLA, Instituto de Limnología "Dr. Raúl A. Ringuelet”, Buenos Aires; LIRP, Laboratório de Ictiologia de Ribeirão Preto, Universidade de São Paulo, Ribeirão Preto; MCP, Museu de Ciências da Pontifícia Universidade Católica, Porto Alegre; MLP, Museo de La Plata, La Plata; MNRJ, Museu Nacional, Rio de Janeiro; MZUSP, Museu de Zoologia da Universidade de São Paulo, São Paulo; NMW, Naturhistorisches Museum Wien, Wien; UFRJ, Universidade Federal do Rio de Janeiro, Rio de Janeiro; UMMZ, University of Michigan Museum of Zoology, Ann Arbor; USNM, National Museum of Natural History, Smithsonian Institution, Washington, D.C.; and ZMUC, Zoologisk Museum, Københavns Universitet, Copenhagen.

Anatomical abbreviations: abt4 — anterior branch of transverse process of vertebra 4; ac — anterior ceratohyal; acn — accessory cartilaginous nodule; acp — articular cleithral process; af — anterior fontanel; an —antorbital; ap-autopalatine; ar-angulo-articulo-retroarticular; at-antorbital tubule; bb2, 3, and 4- 
basibranchials 2 to 4; bl—Baudelot's ligament; bo-basioccipital; br-branchiostegal rays; brl—branchiostegal ray 1; bs - basipterygium; cb1-5 - ceratobranchials 1 to 5; cf — caudal artery foramen; ck - coracoid keel; cla—claustrum; cle — cleithrum; co—coronomeckelian bone; cp — coracoid process; de — dentary; df — dorsal foramen; dh-dorsal hypohyal; drc — complex distal radial; dr1-4 - distal radials 1 to 4; eap- external anterior process (or anterolateral arm); eb1-5-epibranchials 1 to 5; ec —ethmoidean cartilage; en — entopterygoid; ep-epioccipital; epu-epural; es-extrascapular; ex-exoccipital; fr-frontal; ha+has-complex hypurapophysis (hypurapophysis and secondary hypurapophysis fused); hb1-3-hypobranchials 1 to 3; hfhyomandibular facet; hfen-foramen for entrance of hyoid ramus of hyodeomandibular nerve trunk; hmccanal for hyodeomandibular nerve trunk; hmen-foramen for entrance of hyodeomandibular nerve trunk; hmex - foramen for exit of hyodeomandibular nerve trunk; hu1+hu2 - ventral hypural plate formed by coossification of hypurals 1 and 2; hu3+hu4+hu5-dorsal hypural plate formed by co-ossification of hypurals 3 , 4, and 5; hy_hyomandibula; iap — internal anterior process (or anteromedial arm); ib-inner mandibular barbel; ic —inter-ceratohyal cartilage; if — foramen for exit of infraorbital trunk nerve; ih—interhyal; il—inner lip; int - intercalarium; io - interopercle; i1 —infraorbital sensory branch 1; i2 -infraorbital sensory branch 2 (antorbital branch); i3-6 - infraorbital sensory branches 3 to 6; le-lateral ethmoid; 111 — lateral line sensory branch 1 (supracleithral sensory branch); lm—ligamentum mandibulo-hyoid; lp—lateral process; lsh—lateral shelf; 1su—labial sulcus; ma — mesocoracoid arch; mc —-Meckel cartilage; me — mesethmoid; mfen — foramen for entrance of mandibular ramus of hyodeomandibular nerve trunk; $\mathrm{mt}$ - metapterygoid; $\mathrm{mx}$ - maxilla; nanasal; nf—neural foramen; nl—neural lamina (neural arches of vertebrae 3 and 4); ns4— neural spine of vertebra 4; ob —outer mandibular barbel; of —optic foramen; ol—outer lip; op —opercle; os— orbitosphenoid; pa-parasphenoid; pbt4-posterior branch of transverse process of vertebra 4; pb1, 3, 4- pharyngobranchials 1, 3, and 4; pc-posterior ceratohyal; pcb-posterior complex bone of pectoral girdle (coracoid, mesocoracoid, and scapula fused); pcp — postcleithral process; pf — posterior fontanel; ph—parhypural; pm1-10 — preoperculomandibular sensory branches 1 to 10; pop-preopercle; po1+pm11-postotic-preoperculomandibular complex sensory branch (postotic sensory branch 1+ preoperculomandibular sensory branch 11); po2 - postotic sensory branch 2 (pterotic or temporal branch); po3 - postotic sensory branch 3; ppr-posterior process; pre - premaxilla; pro - prootic; pr1-2—proximal radials 1 and 2; ps—pterosphenoid; pt—pterotic; pu1+u1— complex centrum composed of preural centrum 1 and ural centrum 1; pu2-preural centrum 2; qu-quadrate; rpr1—rigid part of pectoral-fin ray 1; sca—scaphium; soc—supraoccipital; sp—sphenotic; spo-subpreopercle; spr1—soft part of pectoral-fin ray 1; st1-4—suborbital tubules 1 to 4; sup — supracleithrum; s1—supraorbital sensory branch 1; s2-supraorbital sensory branch 2; s2+i2-supraorbital-infraorbital complex sensory branch (supraorbital sensory branch 2+ infraorbital sensory branch 2); s3 - supraorbital sensory branch 3; s4-supraorbital sensory branch 4; s6-supraorbital sensory branch 6 (epiphyseal branch); s7-supraorbital sensory branch 7 (postorbital branch); s8 - supraorbital sensory branch 8 (parietal branch); tf-trigeminofacial foramen; tp - tooth plate; tri-tripus; tv4 - transverse process of vertebra 4; tv5-transverse process of vertebra 5; uh-urohyal; up —uncinate process; ur—uroneural; vh—ventral hypohyal; vl—ventrolateral limb of supracleithrum; vm—ventromedial limb of supracleithrum; and vo-vomer.

Comparative material of Heptapteridae examined for this study is listed in Appendix.

\section{Rhamdella cainguae new species}

(Figs. 1 and 2)

Rhamdella sp.—López et al. 2003 (citation: 63).

Holotype. ILPLA 1078, 130.0 mm SL, male, Argentina, Provincia Misiones, Departamento Cainguás,

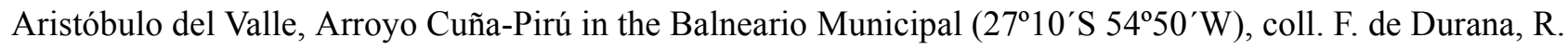
Filiberto and H. Oñatibia, 22-26.ix.1997. 
Paratypes. ILPLA 468, 2 males in alcohol (115.0-140.0 mm SL) and 1 male C \& S (114.0 mm SL), same locality and collectors as holotype, 20.vii.1996; ILPLA 1019, 4 males (116.0-125.0 mm SL), 5 females (100.0-126.8 mm SL mm SL), 1 indet. (88.0 mm SL), 1 male C \& S (138.0 mm SL), LIRP 3045, 1 male in alcohol (153.8 mm SL), 1 female in alcohol (107.2 mm SL), and 1 male C \& S (149.9 mm SL), MLP 9530, 1 male (129.0 mm SL), MNRJ 23157, 1 male (153.2 mm SL), MZUSP 81427, 1 female (124.6 mm SL), same locality and collectors as holotype, 18-22.ix.1997; ILPLA 1079, 3 males (113.9-157.5 mm SL), same locality as holotype, coll. L. Alcalde and R. Filiberto, 25-27.vii.1998; ILPLA 1354, 1 male (122.4mm SL) and 2 females (100.7-107.7 mm SL), same locality as holotype, coll. R. Filiberto, H. López and E. Etcheverry, 18.iii.2000; ILPLA 1176, 2 males (148.7-153.4 mm SL), Argentina, Provincia Misiones, Departamento Cainguás, Aristóbulo del Valle, Arroyo Tateto, on road to La Misión, coll. R. Filiberto, A. Miquelarena and M. Montenegro, 18-22.ix.2000.

Diagnosis. Rhamdella cainguae is autapomorphically diagnosed by having a distinct and large ovoid area in the supraorbital laterosensory canal between the frontal and sphenotic delimited by the apparently slender dorsal walls of these bones and with no foramen for a laterosensory branch. The new species is further distinguished from congeners by the following combination of characters: from $R$. aymarae Miquelarena and Menni 1999, by a shorter maxillary barbel (barbel tip reaching from the base of pectoral-fin ray in a $88.0 \mathrm{~mm}$ SL specimen, to the posterior portion of opercular region, not surpassing the branchial slit, in a $157.5 \mathrm{~mm} \mathrm{SL}$ specimen vs. tip reaching to vertical through close to the dorsal-fin base in a $90.0 \mathrm{~mm}$ SL specimen, to the vertical through the dorsal-fin origin in a $150.0 \mathrm{~mm}$ SL specimen), larger horizontal eye diameter (20.6-23.9\% of HL vs. $11.5-17.3 \%$ ), lesser interorbital distance (17.9-20.7\% of HL vs. 30.0-44.9\%), snout profile slightly convex (vs. snout profile distinctly straight), more numerous branchiostegal rays (seven vs. six), branchiostegal membranes not reaching the basal part of the first pectoral-fin ray in most specimens (vs. extending over the basal part of first pectoral-fin ray in most specimens), shorter interdorsal length (7.6-11.3\% of SL vs. $30.0-44.9 \%)$, longer adipose-fin base (36.0-41.6\% of SL vs. 18.5-27.9\%), longer anal-fin base (16.6-22.0\% of SL vs. 12.3-17.8\%), more numerous anal-fin rays (16-18, commonly 17, vs. 15-16); and dorsal caudal-fin lobe much longer than ventral lobe (length of ventral caudal-fin lobe is $55.8-65.5 \%$ of length of dorsal lobe in males vs. 81.4-94.3\%); from $R$. eriarcha (Eigenmann and Eigenmann 1888) by the dorsal caudal-fin lobe much longer than ventral lobe (length of ventral caudal-fin lobe $55.8-65.5 \%$ of length of dorsal lobe in males vs. 75.0-94.7\%); from $R$. longiuscula Lucena and Silva 1991, by the smaller horizontal eye diameter (20.6$23.9 \%$ of HL vs. $22.5-29.4 \%$ ), larger interorbital distance (17.9-20.7\% of HL vs. $12.8-17.7 \%$ ), greater snout length (37.9-43.2\% of HL vs. $28.3-37.5 \%$ ), snout profile slightly convex but almost straight (vs. snout profile distinctly convex), and branchiostegal membranes not reaching the basal part of the first pectoral-fin ray in most specimens (vs. extending over the basal part of the first pectoral-fin ray); and from $R$. rusbyi Pearson 1924, by shorter maxillary barbels (their tips reaching from the base of the pectoral-fin ray in a $88.0 \mathrm{~mm}$ SL specimen, to the posterior portion of opercular region, but not surpassing the branchial slit in a $157.5 \mathrm{~mm} \mathrm{SL}$ specimen vs. tip reaching to the vertical through the posterior end of the dorsal-fin base or slightly surpassing that point in specimens of 134.2 to $183.8 \mathrm{~mm} \mathrm{SL}$ ), smaller interorbital distance (17.9-20.7\% of HL vs. 26.5$27.1 \%$ ), higher number of branchiostegal rays (seven vs. six), shorter pelvic fin (13.3-16.9\% of SL vs. 17.0$19.1 \%$ ), longer anal-fin base (16.6-22.0\% of SL vs. 11.8-14.0\%), higher number of anal-fin rays (16-18 analfin rays, commonly 17 , vs. 12-14); and dorsal caudal-fin lobe much longer than ventral lobe (length of ventral caudal-fin lobe 55.8-65.5\% of length of dorsal lobe in males vs. 84.8-93.7\%); a dense concentration of long and slender papillae on the lateral body surface in the pectoral and abdominal regions, most conspicuous near the lateral line, resulting in a hairy aspect (vs. papillae comparatively much longer and larger, especially proximate to lateral line); and by the presence of a distinct narrow dark mid lateral stripe (vs. stripe absent).

Remarks. Miquelarena and Menni (1999) utilized the degree of ossification and branching of the lateral line as distinguishing features between $R$. rusbyi and $R$. aymarae. The degree of ossification and branching of the lateral line of $R$. rusbyi, with well-developed ossicles extending posterior to the middle of caudal fin, is the 
most extreme condition among Rhamdella species, where ossification of the lateral line otherwise reaches only to the level of the anal fin. However, those characters were observed in only one specimen of $R$. rusbyi (CAS 63729), which is larger than any C \& S specimen of other Rhamdella species. Since large individuals tend to have a higher degree of ossification and branching of the laterosensory system than small ones, the degree of ossification and branching of the lateral line of $R$. rusbyi may be due to large size only.

TABLE 1. Morphometrics of holotype and fifteen paratypes of Rhamdella cainguae.

\begin{tabular}{|c|c|c|c|c|c|c|c|}
\hline \multirow{3}{*}{ Sex } & \multirow{3}{*}{$\begin{array}{c}\text { Holotype } \\
\text { male }\end{array}$} & \multicolumn{6}{|c|}{ Paratypes } \\
\hline & & \multicolumn{3}{|c|}{10 males } & \multicolumn{3}{|c|}{5 females } \\
\hline & & Range & Mean & SD & Range & Mean & SD \\
\hline Standard length $(\mathrm{mm})$ & 130 & $113.9-157.5$ & & & $100-126.8$ & & \\
\hline \multicolumn{8}{|l|}{ Percentage of standard length } \\
\hline Body depth & 17.7 & $14.6-19.0$ & 16.8 & 1.5 & $16.6-19.5$ & 18.0 & 1.2 \\
\hline Body width & 16.9 & $17.0-19.5$ & 17.9 & 0.7 & $18.4-20.7$ & 19.2 & 1.0 \\
\hline Head length & 26.1 & $25.8-28.8$ & 26.7 & 0.9 & $27.4-29.2$ & 28.4 & 0.8 \\
\hline Head width & 17.7 & $17.0-19.5$ & 18.3 & 0.8 & $18.9-21.0$ & 20.0 & 0.8 \\
\hline Prepectoral length & 24.3 & $24.0-28.0$ & 25.6 & 1.2 & $26.0-29.4$ & 27.9 & 1.3 \\
\hline Predorsal length & 34.4 & $33.3-38.4$ & 36.0 & 1.6 & $37.3-40.4$ & 39.2 & 1.3 \\
\hline Preventral length & 47.7 & $45.7-50.4$ & 48.5 & 1.3 & $48.7-53.3$ & 51.2 & 2.2 \\
\hline Preanal length & 60.8 & $60.0-64.3$ & 62.4 & 1.5 & $63.9-68.4$ & 66.2 & 1.6 \\
\hline Preadipose length & 52.8 & $53.3-57.7$ & 55.9 & 1.7 & $57.6-60.6$ & 58.9 & 1.2 \\
\hline Length of pectoral spine & 13.1 & $11.9-14.0$ & 12.9 & 0.7 & $13.1-14.1$ & & 0.4 \\
\hline Length of dorsal spine & 11.1 & $9.5-13.2$ & 11.4 & 1.4 & $9.5-11.8$ & 10.5 & 0.9 \\
\hline Length of ventral fin & 14.6 & $13.3-16.9$ & 14.9 & 1.2 & $15.0-16.0$ & 15.5 & 0.5 \\
\hline Dorsal-fin base & 14.6 & $13.3-16.5$ & 14.5 & 1.1 & $12.5-14.6$ & 13.9 & 1.0 \\
\hline Anal-fin base & 19.5 & $18.6-22.0$ & 20.3 & 1.1 & $16.6-19.3$ & 18.1 & 1.2 \\
\hline Adipose-fin base & 39.7 & $37.5-41.6$ & 39.6 & 1.3 & $36.0-41.5$ & 38.2 & 2.1 \\
\hline Caudal peduncle length & 22.0 & $21.2-24.6$ & 22.5 & 1.0 & $21.7-23.6$ & 22.8 & 0.7 \\
\hline Caudal peduncle height & 9.0 & $8.5-10.1$ & 9.1 & 0.6 & $9.0-9.8$ & 9.3 & 0.4 \\
\hline Adipose height & 4.6 & $4.1-5.3$ & 4.5 & 0.4 & $4.2-5.6$ & 4.8 & 0.5 \\
\hline Distance dorsal-adipose & 8.8 & $7.6-10.3$ & 8.9 & 0.9 & $8.5-11.3$ & 9.8 & 1.2 \\
\hline Urogen. papilla-anal-fin origin & 2.8 & $2.6-3.5$ & 3.1 & 0.3 & $4.7-5.1$ & 4.9 & 0.2 \\
\hline \multicolumn{8}{|l|}{ Percentage of head length } \\
\hline Bony interorbital width & 20.0 & $17.9-20.3$ & 18.9 & 0.7 & $18.2-20.7$ & 19.1 & 1.0 \\
\hline Eye diameter & 21.2 & $20.6-23.9$ & 22.4 & 0.9 & $22.6-23.5$ & 23.1 & 0.4 \\
\hline Head height & 50.0 & $48.9-59.7$ & 52.1 & 3.6 & $51.6-57.1$ & 53.7 & 2.1 \\
\hline Mouth width & 30.6 & $25.8-36.9$ & 32.7 & 3.0 & $28.6-33.5$ & 31.3 & 2.4 \\
\hline Snout length & 42.6 & $38.3-43.2$ & 41.4 & 1.6 & $37.9-41.2$ & 39.5 & 1.2 \\
\hline Internarial length & 22.6 & $21.6-24.7$ & 22.8 & 1.1 & $21.7-23.5$ & 22.9 & 0.7 \\
\hline Internarial width & 21.2 & $19.4-21.4$ & 20.8 & 0.6 & $19.3-22.0$ & 20.2 & 0.8 \\
\hline
\end{tabular}


Description. Morphometric data are given in Table 1. Cross-section of trunk roughly elliptical at level of dorsal-fin origin, gradually more compressed posterior to dorsal-fin base. Caudal peduncle region compressed, merging with caudal fin from dorsal view. Anterodorsal profile of body gently convex, curving in an even arch from snout to base of dorsal fin, except for discrete depression at base of supra-occipital process. Dorsal profile gently concave to straight from dorsal-fin base to adipose-fin origin and approximately straight or gently convex from that point to base of caudal fin. Ventral body profile in a continuous convex curve from mouth to pelvic-fin base. Ventral profile of body straight from pelvic-fin insertion to caudal-fin base. Fortyone to 43 myotomes apparent through skin; myotomes becoming progressively narrower and more angled posteriorly. No deposits of fatty material in globose bodies, commonly seen in heptapterids, perceptible through the skin. Pectoral pore absent. Anus and urogenital pore very close to each other.

Skin of top and underside of head, as well as opercular and branchiostegal regions with dense covering of papillae; lateral surface of the pectoral and abdominal regions, approximately to vertical through posterior end of dorsal-fin base with long, slender papillae that give a hairy aspect to that region; papillae most concentrated near lateral line. Skin of ventral surface of body apparently without papillae.

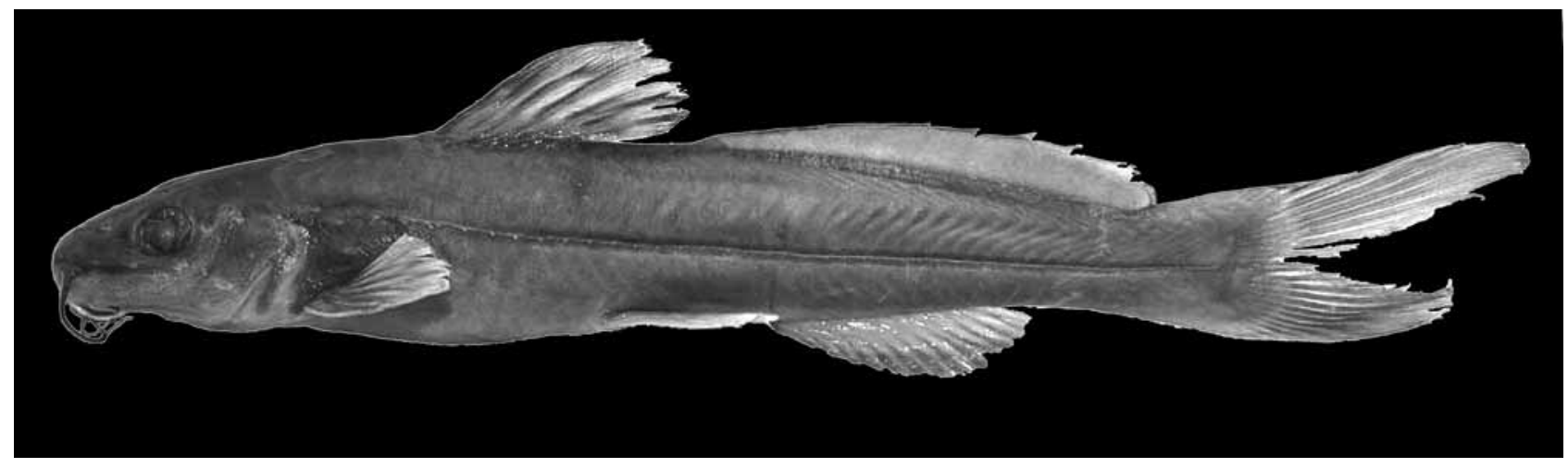

FIGURE 1. Rhamdella cainguae n. sp., ILPLA 1078, male, $130.0 \mathrm{~mm}$ SL, holotype, Arroyo Cuña-Pirú, Aristóbulo del Valle, in the Balneario Municipal, Departamento Cainguás, Provincia Misiones, Argentina (27 $\left.10^{\prime} \mathrm{S} 054^{\circ} 50^{\prime} \mathrm{W}\right)$.

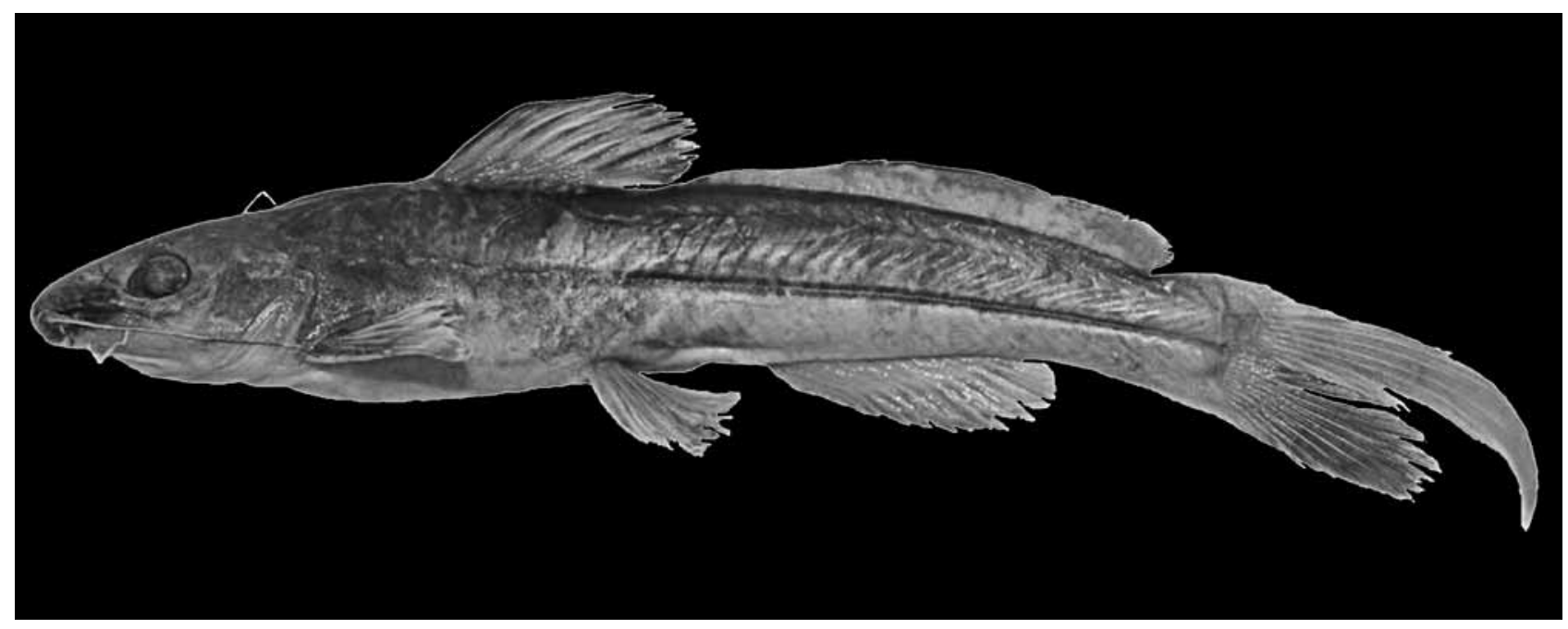

FIGURE 2. Rhamdella cainguae n. sp., ILPLA 468, male, $140.0 \mathrm{~mm}$ SL, paratype, Arroyo Cuña-Pirú, Aristóbulo del Valle, in the Balneario Municipal, Departamento Cainguás, Provincia Misiones, Argentina (27º $\left.10^{\prime} \mathrm{S} 054^{\circ} 50^{\prime} \mathrm{W}\right)$.

Head long (greater than $25 \%$ of SL), narrow (its greatest width about $0.7-0.8$ times its length), deep (its greatest depth nearly $0.5-0.6$ times its length), and elliptical in dorsal view (Figs. 3-5). Deep longitudinal facial ridge marking dorsal limits of adductor mandibulae muscle, extending from base of maxillary barbel to 
or just anterior of level of fourth infraorbital pore (i4). Distance between posterior nares slightly greater than that between anterior nares. Anterior and posterior nares far apart, with separation slightly less than distance between anterior and posterior nares. Four nares arranged as in vertices of an square. Anterior nare tubular with lateral or posterolateral limit adjacent to anteriormost supraorbital pore (s1) and anteromedial to anteriormost infraorbital pore (i1). Anterior nare close to upper lip. Posterior nare rounded, situated immediately anterior to third supraorbital pore (s3), with high, anteriorly deepest, raised margin, surrounding it almost completely, other than at posterolateral point. Posterior nares about midway between anterior nares and posterior margin of eye. Posterior nare lacking barbel. Adductor mandibulae muscles restricted to facial region, accommodated on lateral wall of hyomandibula, and not extending dorsally to midline of head. Levator operculi muscle inserted on the dorsal and dorsoposterior portion of opercle.

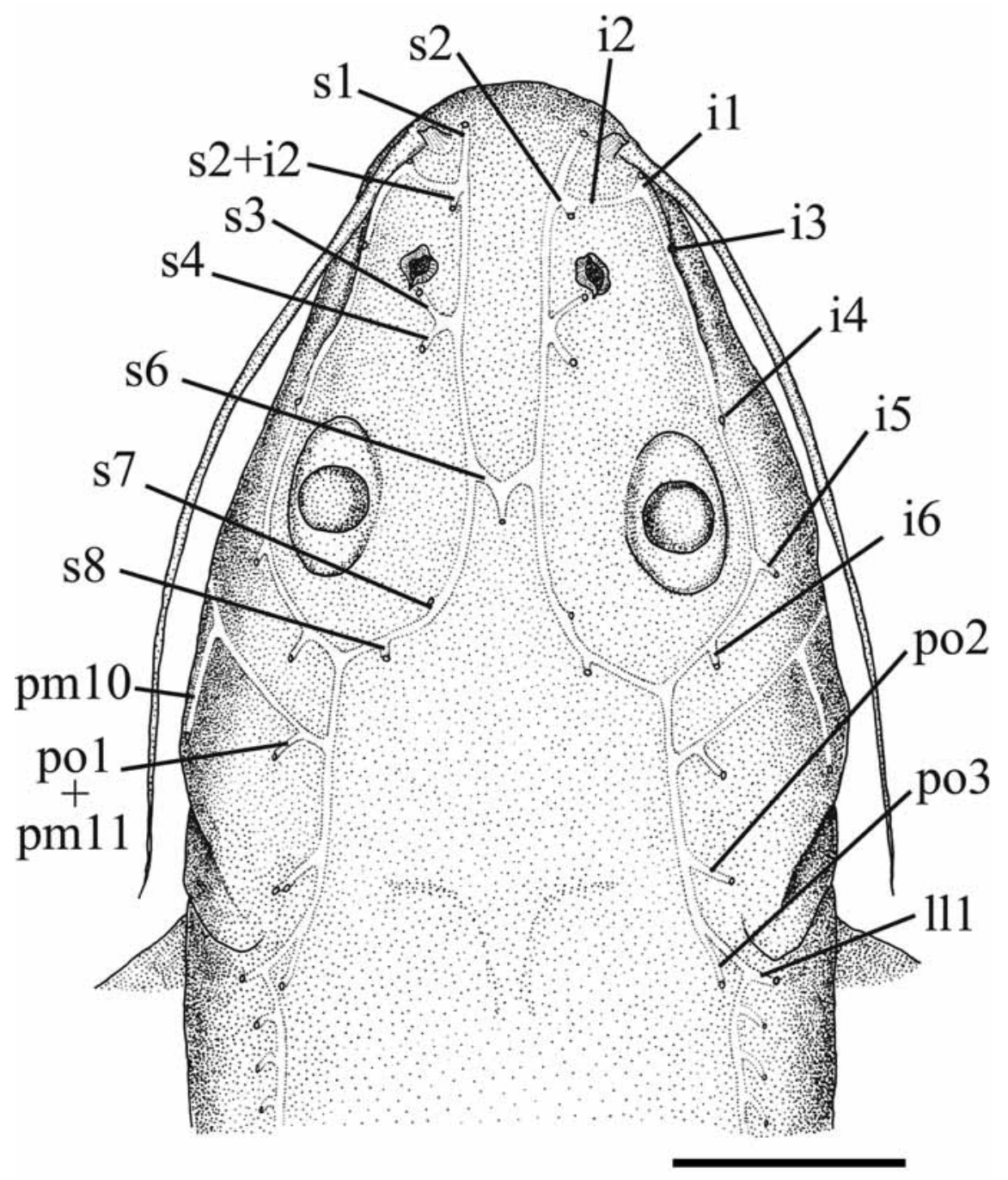

FIGURE 3. Head of Rhamdella cainguae, LIRP 3045, male, $153.8 \mathrm{~mm}$ SL, paratype, showing laterosensory canals. Dorsal view. Scale bar $=10 \mathrm{~mm}$.

Mouth wide, subterminal, with snout projecting slightly beyond jaw (Figs. 4 and 5). Gape transverse, slightly ventrally curved at corners, with fleshy rictal fold at corners. Rictal fold well developed, ventrally subtended by submandibular groove that extends dorsally around corner of mouth posterior to upper part of rictal fold and ventrally to point between second and third preoperculomandibular pores (pm2 and pm3). Both upper and lower lips subdivided by a deep depression into two transverse folds; with several longitudinal plicae. Premaxillae, dentaries and pharyngeal tooth plates with small villiform teeth arranged in bands. Tooth- 
bearing portion of premaxillae long and narrow, rectangular, with projections onto posterolateral angle of bone, and usually partially in contact at symphysis. Dentary tooth patch slender and posteriorly elongate. Palate edentulous. Upper and lower oral valves thin, covered by papillae, with posterior margins concave. Upper oral valve totally free posteriorly. Lower oral valve broadly attached anteriorly to mouth floor just behind dentary dentition, and with free rounded flaps posteriorly. Upper valve approximately as long as upper tooth plate, its length decreasing progressively posteriorly; lower valve narrower anteriorly and progressively wider posteriorly, forming large posterior flaps. Mouth roof and floor with sparse papillae.

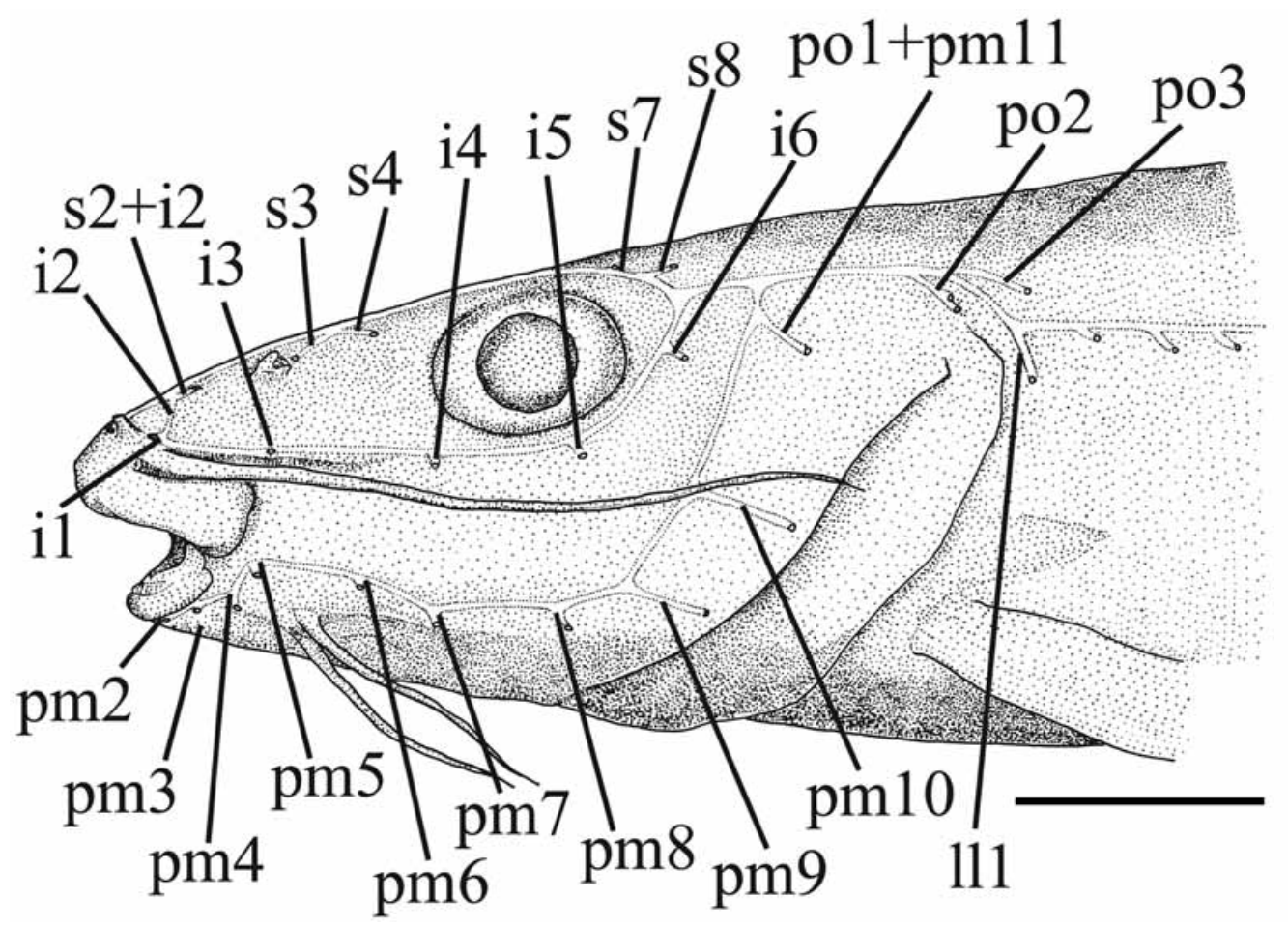

FIGURE 4. Head of Rhamdella cainguae, LIRP 3045, male, $153.8 \mathrm{~mm}$ SL, paratype, showing laterosensory canals. Left view. Scale bar $=10 \mathrm{~mm}$.

Barbels short, slender, and tapering progressively towards their distal extremities (Figs. 3-5). Barbels approximately ovoid in cross section, without fringing membrane. Maxillary barbel, longest, inserts above upper lip lateral to anterior nare and adjacent to anteriormost pore of infraorbital laterosensory canal (i1). Tip of adpressed maxillary barbel reaches branchiostegal membrane (but not surpassing the branchial slit) in larger specimens; and reaches posteriormost third of first pectoral-fin ray, in advance of dorsal-fin origin, in smaller specimens. Mental-barbel base inserted midway between anterior border of lower jaw and gular fold. Outer mental barbel longer than inner barbel, and inserted nearly behind fourth pore of preoperculomandibular laterosensory canal (pm4). Tip of adpressed outer mental barbel reaches from point slightly posterior to the branchiostegal fold to point slightly beyond outer border of branchiostegal membrane. Inner mental barbel inserted slightly in advance of vertical through origin of outer mental barbel, approximately behind second pore of preoperculomandibular laterosensory canal (pm2). Tip of adpressed inner mental barbel reaches from point just posterior to branchiostegal fold to point almost at outer border of branchiostegal membrane.

Gular fold distinct, fleshy, and broadly V-shaped with rounded apex (Fig. 5). Posteroventral portion of opercle and branchiostegal region delimited by a distinct ridge on lateral surface of head extending from distal tip of opercle to a point between eighth and ninth pores of preoperculomandibular canal (pm8 and pm9), ventrally. 


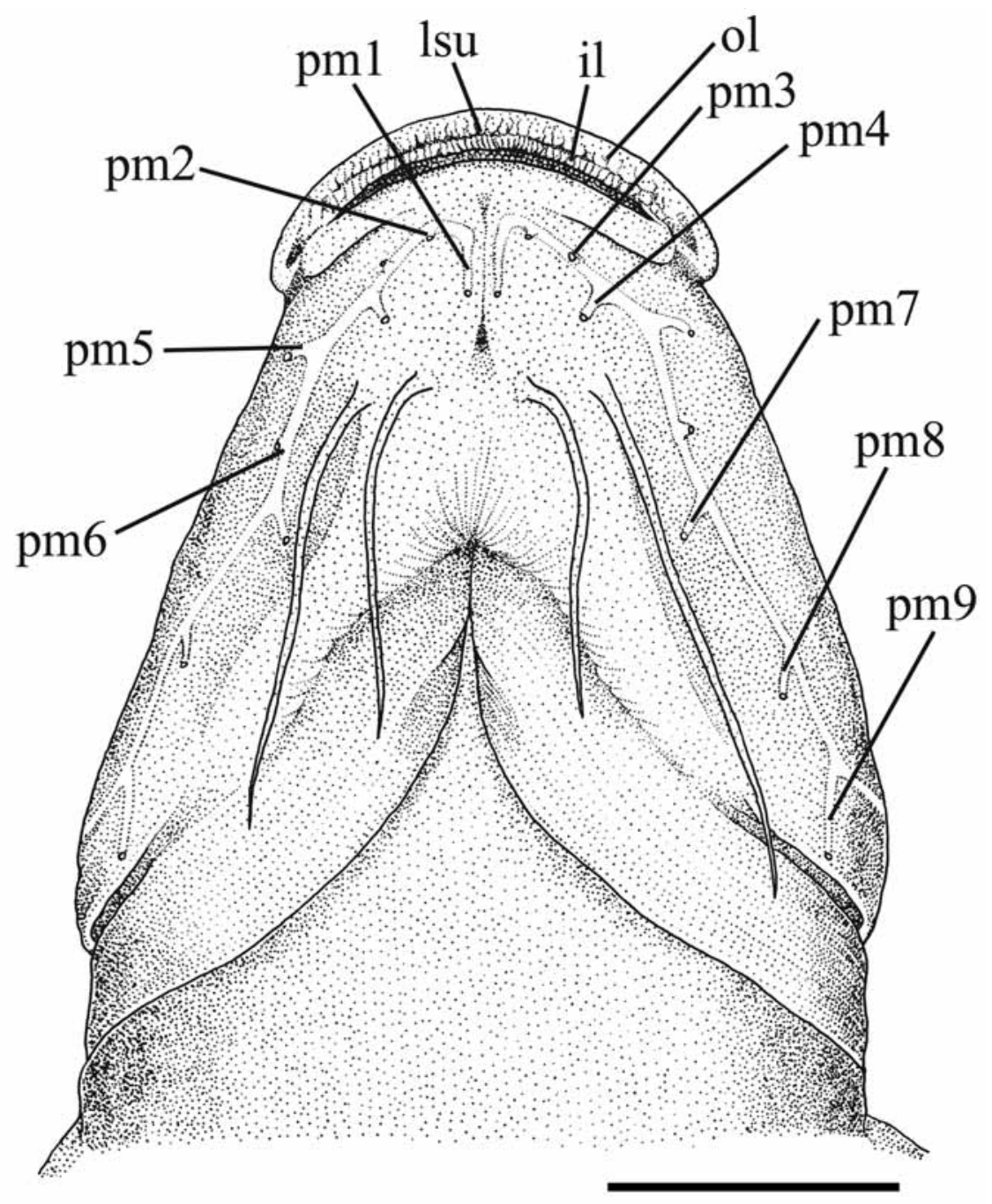

FIGURE 5. Head of Rhamdella cainguae, LIRP 3045, male, $153.8 \mathrm{~mm} \mathrm{SL}$, paratype, showing laterosensory canals. Ventral view. Scale bar $=10 \mathrm{~mm}$.

Branchiostegal membranes well developed, thick, united to isthmus only at medial apex, and firmly connected to each other anteriorly (Fig. 5). Branchiostegal membrane not reaching base of first pectoral-fin ray and not overlapping ventrally. Gill rakers thick and moderately long, with: 4 (1), 5 (1), 6 (6*), 7 (3), or 9 (1) rakers on first ceratobranchial, and $1(3), 2(7)$, or $3\left(2^{*}\right)$ on first epibranchial, plus $1\left(12^{*}\right)$ on angle formed by these bones.

Eyes large, elliptical (greatest length in longitudinal axis), with rims circumscribed with deep, continuous invagination, distinctly more pronounced at anterior and dorsal borders (Figs. 3 and 4). Skin over eye thin and transparent, with lens clearly visible. Eye dorsolaterally positioned, centered approximately at midpoint between tip of snout and corner of opercular membrane and situated proximate to each other, being separated by a space slightly larger than longitudinal diameter of eye. Pupil rounded.

Dorsal fin distally rounded in profile, reaching to adipose fin when adpressed. First dorsal-fin ray (spinelet) very small (not externally visible), triangular and with two ventral limbs, followed by 1 long unbranched, and $6\left(10^{*}\right)$ or 7 (2) branched rays. Second dorsal-fin ray with most of proximal portion stiffened (54.2-67.4\% of entire length) and with segmentation perceptible solely distally, forming delicate spine, and shorter distal portion flexible and clearly segmented. Spiny portion of the second dorsal-fin ray straight, approximately ovoid in cross-section, and lacking marginal dentations. Second dorsal-fin ray slightly shorter than third and 
fourth rays (first and second branched rays, respectively), whose tips project beyond tip of second dorsal-fin ray. Origin of dorsal fin approximately on vertical through the posterior portion of mid third or anterior portion of most posterior third of adpressed pectoral fin.

Pectoral fin with distal margin slightly convex, with 1 unbranched and $8(3), 9\left(6^{*}\right)$, or 10 (3) branched rays. First pectoral-fin ray covered by thick integument; convex anteriorly and straight to slightly concave dorsally. Most of proximal part of first ray rigid and with hardly perceptible segmentation (72.0-82.6\% of its entire length), forming a distinct spine; shorter distal portion flexible and clearly segmented. First pectoral-fin ray approximately as long as second (first branched) and third (second branched) rays, but tips of second and third rays projecting slightly beyond the tip of first ray. Spiny part of first pectoral-fin ray with 11-17 conspicuous, regularly spaced dentations along posterior margin, and 26-46 dentations smaller than posterior dentations along its anterior margin (88.0-153.4 mm SL). There is no evidence of sexual or ontogenetic co-relation with the number of dentations. Pectoral fin lying parallel to main body axis when expanded and slightly directed upwards when adpressed to body.

Pelvic fin convex posteriorly, with 6 rays $\left(12^{*}\right)$. Lateral ray unbranched, completely flexible, segmented, and distinctly shorter than second and third rays (first and second branched rays, respectively). Tip of pelvic fin reaches vertical through anal-fin origin. Pelvic-fin origin approximately at or slightly in advance of midpoint of body (excluding caudal fin), and on vertical through base of last dorsal-fin ray.

Anal-fin margin rounded in lateral profile, with $16(2), 17\left(5^{*}\right)$, or 18 (1) rays, including $10(3)$ or $11\left(5^{*}\right)$ branched rays: vi+10 (1), v+11 (1), vii+10 (1), vi+11 (4*), or viii+10 (1). Anal-fin base medium-sized; covered basally with thick muscular tissue. Origin of anal-fin base approximately on vertical through anterior fifth of adipose-fin base. Posterior limit of anal-fin base approximately at vertical through middle of last twothirds of adipose-fin base.

Adipose fin long, forming ascending elevated curve in lateral profile, with highest point approximately at last third. Adipose fin merging gradually with back anteriorly, its origin difficult to pinpoint. Distance from dorsal fin to adipose fin less than length of dorsal-fin base. Origin of adipose fin anterior to middle of trunk, and approximately on vertical through middle of adpressed pelvic fin and through, or just behind, anus. Posterior adipose-fin base well defined, forming posterior free lobe markedly distinct from anteriormost portion of dorsal caudal-fin fold. Vertical through end of adipose-fin base distinctly posterior of tip of last anal-fin rays.

Caudal fin deeply forked, lobes long and broad, with rounded contours and 7 and 8 branched rays in dorsal and ventral lobes, respectively. Total caudal fin-rays 50 (1), 52 (1), or 55 (1), with 24 (1), 25 (1), 26 (1) rays in dorsal lobe and 26 (1), 27 (1), 29 (1) rays in ventral lobe. Dorsal caudal-fin lobe much longer than ventral one, markedly so in males: length of ventral caudal-fin lobe $55.8-65.5 \%$ of length of dorsal lobe in males (9 ex., 121.0-157.5 mm SL) and 77.8-80.8 \% in females (2 ex., 107.2-124.6 mm SL). Membrane uniting dorsal and ventral caudal-fin lobes extending approximately to the extremities of the median rays of the caudal fin.

Color in life. Overall pigmentation varying from uniformly light to dark gray, or spotted (either with light background color and dark irregular blotches or dark background color and lighter irregular blotches), becoming white ventrally. In light-colored specimens fins almost translucent or yellowish with no conspicuous blotches, fin margin dark in some individuals. Dark-colored specimens with all fin rays intensely gray and fin membranes intensely yellow. Dark, narrow stripe extending from posterodorsal margin of opercle to middle caudal-fin rays. All specimens with iridescent yellow and lilac hues. Mental barbels white; maxillary barbels iridescent gray.

Color in alcohol. Upper portion of head and cheeks densely covered by dark pigmentation, becoming gradually less intense ventral to rim of orbit. Head lightly pigmented ventrolaterally and devoid of pigmentation or with scattered melanophores ventrally (at approximately ventral to line of preoperculomandibular canal). Dark ventral pigmentation mostly concentrated around bases of outer mental barbels. Lower lip with dense concentration of dark chromatophores not extending beyond line of mandibular portion of preoperculo- 
mandibular laterosensory canal. Regions around head sensory pores devoid of pigmentation. Maxillary barbel darkly pigmented dorsally and unpigmented ventrally. Mental barbel completely unpigmented or with few melanophores at base. No mask across the eyes, as seen in some Brachyrhamdia species (see Lundberg and McDade 1986; Sands 1985). Overall trunk coloration varying from uniform dark brown to light brown, sometimes with irregularly distributed darker blotches (Figs. 1 and 2). Mid-dorsal region of trunk from dorsal-fin origin to adipose-fin origin typically darker. Lateral surface of trunk with a well-defined narrow stripe of constant width along lateral line with about one third of orbital length. Stripe extends from region immediately behind branchiostegal membrane to bases of median caudal fin-rays. Pectoral and abdominal areas unpigmented except for scattered melanophores behind and below base of pectoral-fin rays, and on areas near base of pelvic-fin rays, and medial portion of basipterygia. Ventral midline posterior to pelvic-fin insertion and along anal-fin base, weakly pigmented. No zone behind the head devoid of pigmentation (unpigmented collar), as exhibited by some Brachyglanis, Cetopsorhamdia, Chasmocranus, and Myoglanis species (see Eigenmann 1912; Schultz 1944). Upper portion of trunk lacking unpigmented areas or dark transverse bars, as in several heptapterid genera (e.g. Heptapterus, Imparfinis, Mastiglanis, Rhamdioglanis, Taunayia etc.). No dark vertical bar along base of the caudal-fin rays, as seen in some Brachyrhamdia species (see Sands 1985). Dorsal-fin rays and adjacent areas of interradial membrane densely pigmented with brown. Dorsal surface of pectoral fin with high concentration of brown or gray chromatophores along rays; interradial membrane translucent, dorsally unpigmented, except for areas adjacent to pectoral-fin rays. Ventral surface of pectoral fin unpigmented or with few scattered small melanophores along rays. Dorsal surface of pelvic-fin rays and adjacent interradial membranes densely covered with brown or gray melanophores. Ventral surface of pelvic fin unpigmented or with few scattered, small chromatophores along rays. Adipose fin with intense concentration of brown or gray chromatophores, and with darker line on its outer margin. Anal-fin rays with dark chromatophores but with most of interradial membrane lacking dark pigmentation except for areas adjacent to fin rays. Muscular basal portion of anal fin and region immediately anterior well pigmented. Caudal-fin rays densely brown-pigmented. Interradial caudal-fin membrane devoid of chromatophores.

Sexual dimorphism. Adult females with urogenital papilla close to anus, urogenital papilla and anus equally wide basally, and papilla with small triangular posterior tip. Adult males with urogenital papilla more distant from anus, base of papilla narrower than anus, and papilla with a more developed triangular posterior tip. Distance from urogenital papilla to anal-fin origin greater in females $(4.5-5.1 \%)$ vs. males $(2.6-3.5 \%$ $\mathrm{SL})$. Dorsal caudal-fin lobe proportionally more developed in males than females.

Distribution. Known only from the type locality, Arroyo Cuña-Pirú, Río Paraná basin, in northeastern Argentina (Fig. 6).

Habitat. Specimens were collected with seine or hook-and-line, over rocky bottoms in a clear water stream (ca. 50-100 cm deep, with pools around $3 \mathrm{~m}$ deep), running through a densely forested subtropical area. Individuals demostrated a tendency for gregarity as they were densely grouped under large stones.

Etymology. From the Guaraní, ca'á (forest) and iguá (inhabitant), in allusion to the Cainguá, indigenous people of northeastern Argentina.

\section{Description of skeleton and laterosensory system in Rhamdella cainguae.}

Cranium (Figs. 7 and 8). The cranial roof bones are ornamented with striae, grooves, and, more rarely, small pits, radiating from the centers of the bones. The dorsal surface of the cranial roof bones is mostly straight or slightly convex and without crests or fossae. The orbital region is well defined in dorsal view, formed by a concavity limited by the outer borders of the lateral ethmoid anteriorly, frontal laterally, and sphenotic posteriorly. The bony interorbital width is narrow (about $20 \%$ of total cranial length, excluding supraoccipital process). The two cranial fontanels are present as long slits separated by a conspicuous epiphyseal bar; the 
anterior fontanel is longer than the posterior one. There is no bony outgrowths covering the fontanels and the epiphyseal bar. The bones of the posterior portion of the cranial roof (frontals, supraoccipital, pterotics, and sphenotics) are joined to each other via typical dentate sutures.

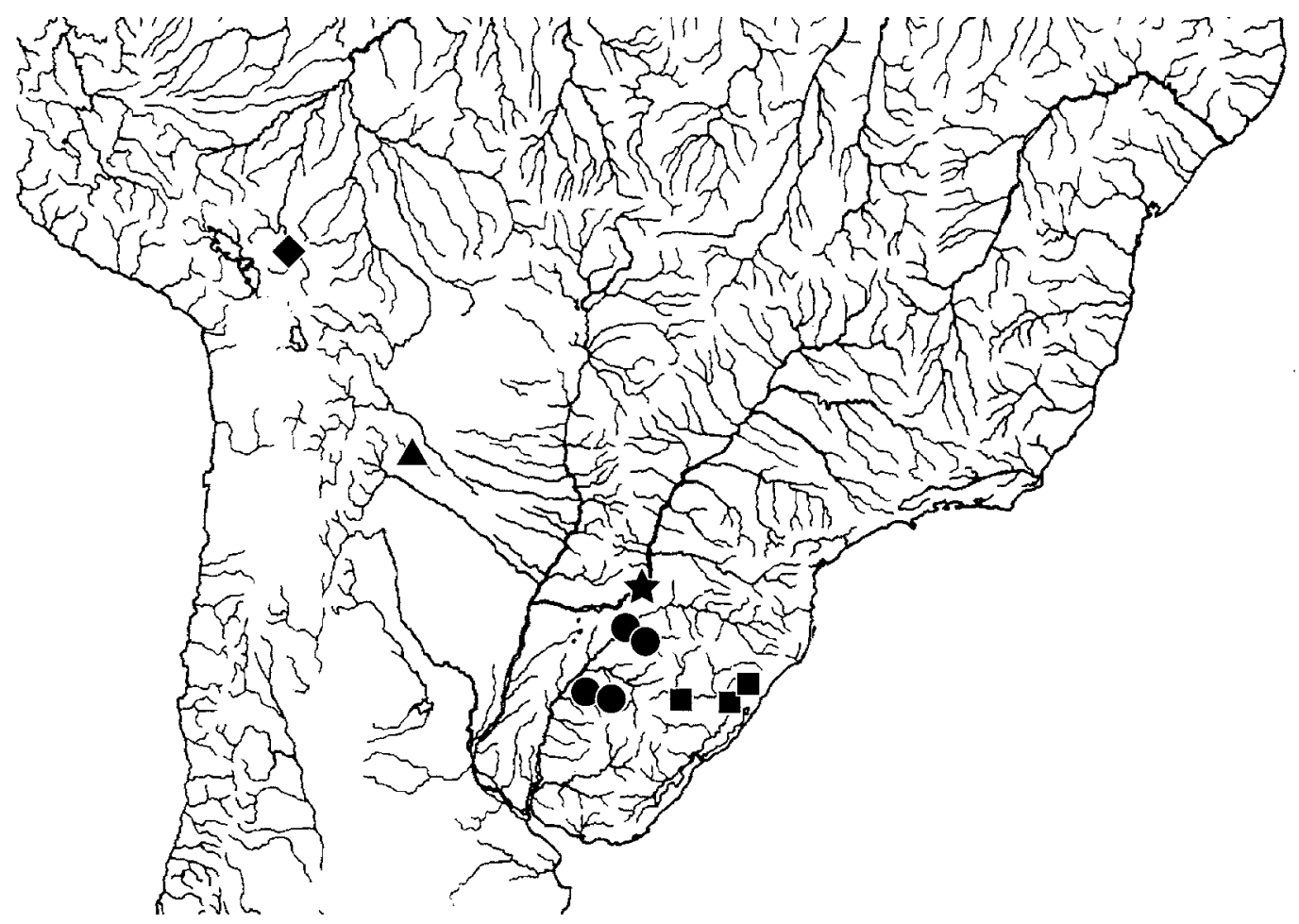

FIGURE 6. Map of southern South America with geographic distributions of Rhamdella species plotted. Symbols: star-Rhamdella cainguae; triangle_-Rhamdella aymarae; square—Rhamdella eriarcha; dot—Rhamdella longiuscula; and lozenge-Rhamdella rusbyi.

Mesethmoid (Figs. 7 and 8). The anterolateral mesethmoid cornu is short, thick, blunt-tipped, and anterolaterally directed. The anterior margin of the cornua are curved continuously, delimiting a shallow median cleft. The anterolateral mesethmoid cornua are primarily in the same horizontal plane as the ventral side of the cranium, and with tips gently curved ventrally. The posterolateral angle of the mesethmoid is anterolaterally projected, forming a conspicuous cornu; the anterior margin of the posterior portion of mesethmoid is continuous, without notches. The region between the posterior border of the mesethmoid and the anterior border of the lateral ethmoid are completely filled by ethmoidean cartilage. The cartilaginous condyle for articulation of the autopalatine has a discrete superficial ossification.

Premaxilla and maxilla (Figs. 7 and 8). The premaxilla is quadrangular, long and narrow; its anterior margin is continuous, without projection; its posterolateral angle is strongly pronounced posteriorly; its dorsal surface has a triangular bony lamina oriented in oblique plane. The premaxilla bears seven or eight irregularly arranged rows of small viliform teeth. The maxilla is small, distally forming a complete osseous tubule around the base of the core of the maxillary barbel.

Autopalatine (Figs. 7 and 8). The autopalatine is rod-like, medium-sized, and has small cartilages at extremities; the anterior cartilage is conical, partially covered by an ossified cap; the posterior cartilage is smaller than the anterior cartilage and is also conical but shows no sign of superficial ossification.

Nasal (Fig. 7). The nasal is short, robust, poorly-ossified, and has an anterior opening for the entry of the anteriormost branch of the supraorbital laterosensory canal (s1), a large dorsolateral opening for the exit of the antorbital (s2) branch, and a posterior opening for the exit of the supraorbital laterosensory canal, from which arises the $\mathrm{s} 3$ branch. 


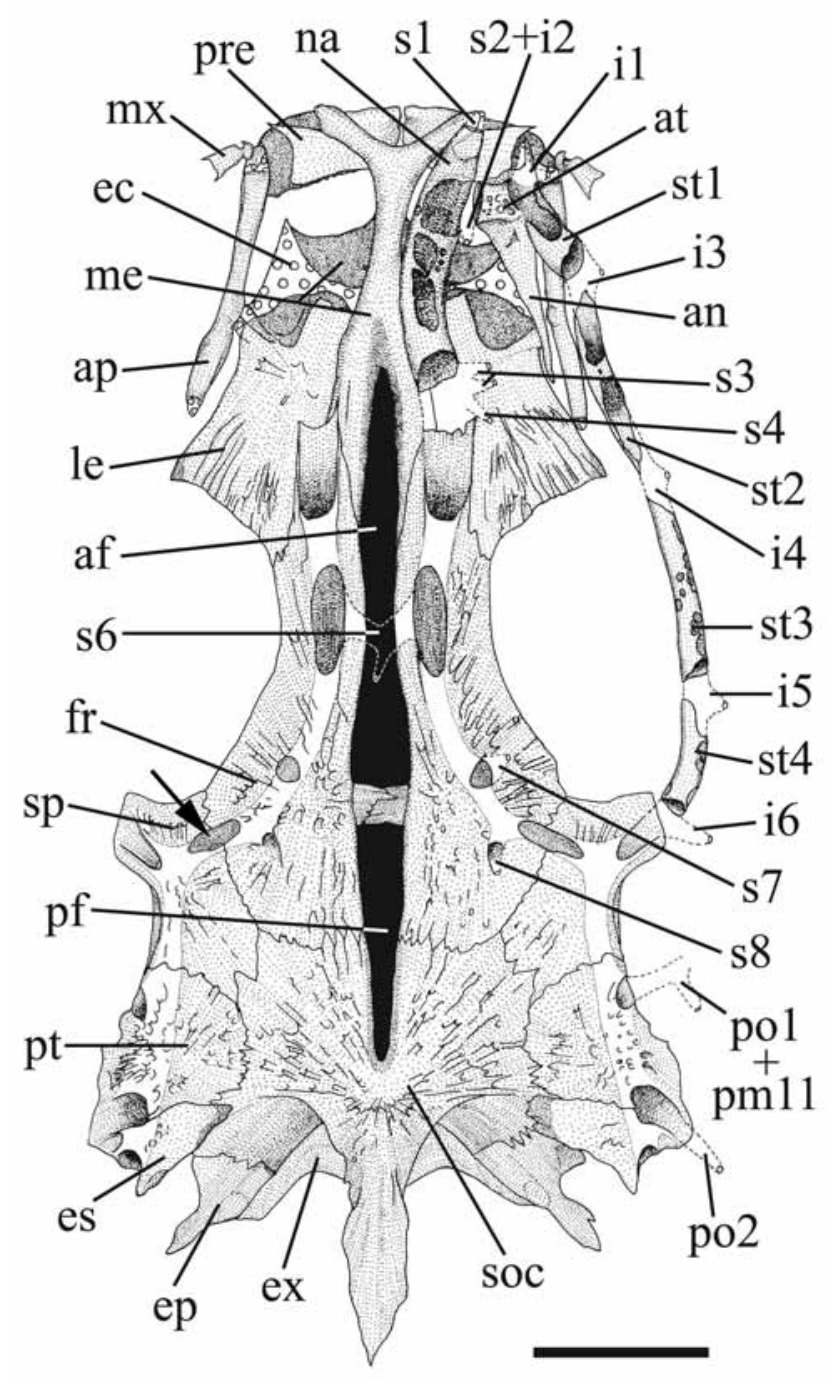

FIGURE 7. Cranium of Rhamdella cainguae, LIRP 3045, male, $149.9 \mathrm{~mm}$ SL, paratype. Dorsal view. Arrow points to frontal-sphenotic space. Scale bar $=5 \mathrm{~mm}$.

Antorbital and suborbital tubules (Figs. 7 and 8). The antorbital is represented by a poorly-ossified triangular lamina with a long rod running along its entire lateroventral border, and has the antorbital tubule and the suborbital 1 firmly co-ossified on its dorsal surface. The antorbital tubule is transversally oriented along the anteromesial portion of the antorbital. The suborbital tubule 1 is obliquely oriented along the anterolateral portion of the antorbital. Four suborbital ossified tubules are present; the suborbital tubules 3 and 4 border the orbit ventrally.

Lateral ethmoid (Figs. 7 and 8). The posterior portion of the lateral ethmoid (the region behind the autopalatine condyle) is more than twice as long as the anterior portion, which accommodates the posterior portion of the olfactory organ. The posterior portion of the lateral ethmoid is approximately rectangular and entirely solid (not perforated); the lateral contour of its posterior portion is slightly concave; its posterolateral angle is pointed and curved ventrally. The articular facet of the lateral ethmoid for autopalatine is short. The lateral ethmoid and the orbitosphenoid are joined to each other via a synchondral unsutured joint.

Frontal (Fig. 7). The profile of the outer margin of the frontal is smooth, without any noticeable processes. The frontal has a tunnel and five openings for passage of the supraorbital laterosensory canal and its branches. The first opening is large, situated at the anterior margin of the frontal and serves for the entrance of the supraorbital laterosensory canal. The second opening is a very long ellipse in outline, situated on the posterior 
portion of the anterior half of the frontal, and allows the exit of the epiphyseal (s6) branch. The third opening is small and ovoid, situated just anterior to the level of the epiphyseal bar, and serves for the exit of the postorbital branch (s7). The fourth opening is small, situated just posterior to the level of the epiphyseal bar, and allows the exit of the parietal (s8) branch. The fifth opening is situated on the posterolateral border of the frontal and serves for the exit of the supraorbital laterosensory canal. Inside the supraorbital laterosensory canal, along the boundary between the frontal and the sphenotic, there is a large distinct area. The dorsal walls of the bones in that region are apparently thinner delimiting an ovoid area, but no foramen for the laterosensory branch is present (Fig. 7, see arrow).

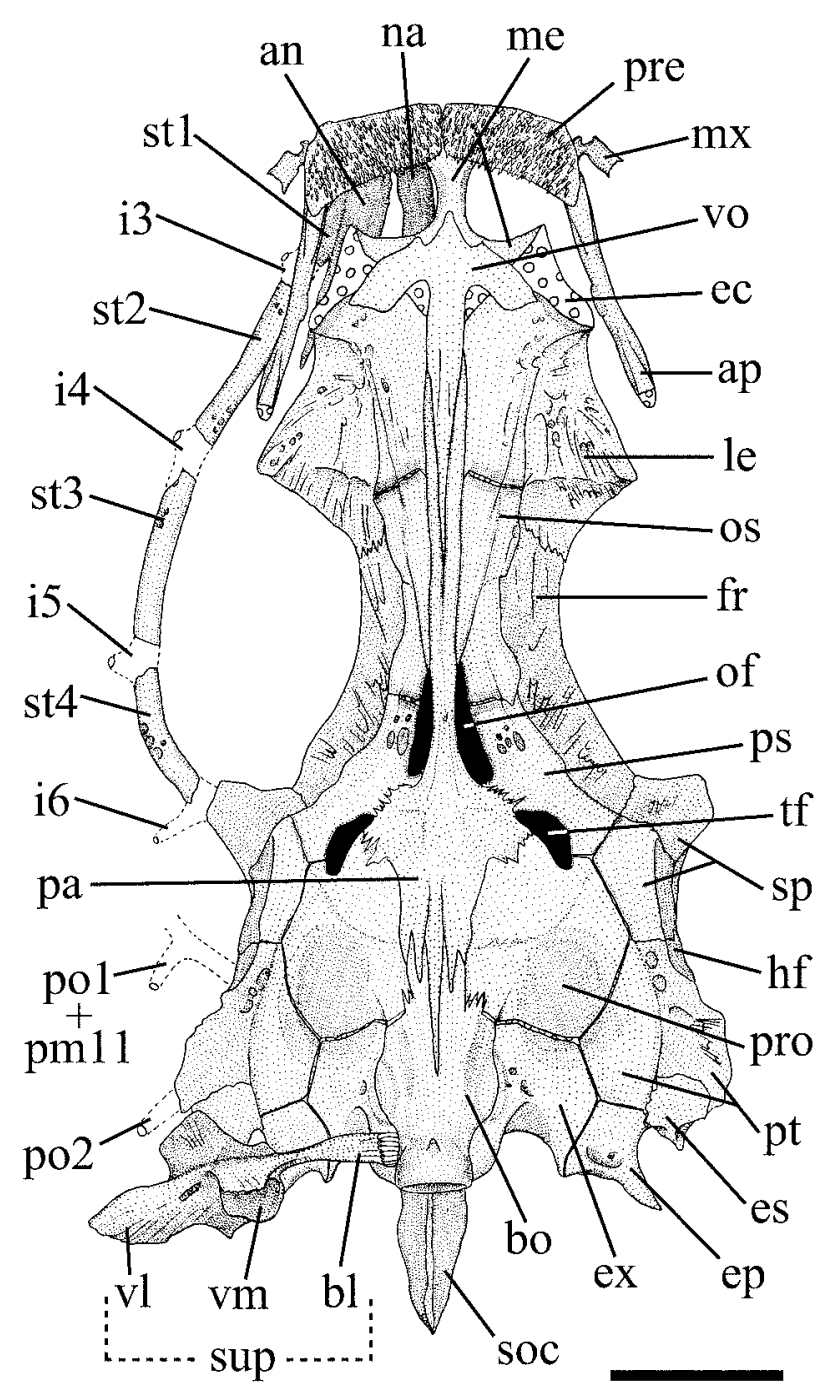

FIGURE 8. Cranium of Rhamdella cainguae, LIRP 3045, male, $149.9 \mathrm{~mm} \mathrm{SL}$, paratype. in Ventral view. Scale bar $=5$ $\mathrm{mm}$.

Sphenotic (Figs. 7 and 8). The longitudinal axis of the sphenotic is nearly as long as that of pterotic. The sphenotic is crossed by the posterior portions of the supraorbital and infraorbital laterosensory canals, and most of the length of the otic canal. The sphenotic bears three openings associated with the laterosensory canals: an anteromesial opening for the entrance of the supraorbital laterosensory canal; a lateral opening for the entrance of the infraorbital laterosensory canal; and a posterior opening for the exit of the otic laterosensory canal. The sphenotic spine is present and acute, and is located on the anterolateral third of bone.

Pterotic (Figs. 7 and 8). The pterotic possesses four openings for the passage of the laterosensory canals and branches: an entrance for the otic laterosensory canal anteriorly; an exit for a short branch of the postotic 
laterosensory canal (po1) laterally, which is fused to the preoperculomandibular laterosensory canal; an opening for the posterolateral branch of the postotic laterosensory canal, the pterotic or temporal (po2) branch, posterolaterally; and the posterior opening for the postotic laterosensory canal.

Extrascapular (Fig. 7). The extrascapular is a medium-sized, transversally oriented, and roughly triangular lamina, which is solidly attached to the posterolateral region of the cranium. The extrascapular is pierced along its dorsolateral border by the end of the postotic laterosensory canal.

Supraoccipital (Figs. 7 and 8). The supraoccipital ("parieto-supraoccipital" of Arratia and Gayet 1995) is composed of the supraoccipital and the parietals enterily co-ossified to each other (Fink and Fink 1981, 1996; Arratia and Gayet 1995; Arratia and Huaquin 1995). The supraoccipital process is medium-sized. The pointed tip of the supraoccipital process does not reach to the midpoint of the complex centra in dorsal view, nor possesses an osseous contact with the nuchal plate. The dorsal surface of the supraoccipital process is concave and its ventral surface has a median keel. The supraoccipital process is not very wide, and its width is approximately constant along its length except for the wide base that does not reach the extrascapulars. The exposed posterior portion of the cranium is nearly rectilinear, and the supraoccipital process is embedded in the skin. The posterior process of the epioccipital that articulates with the upper limb of cleithrum is very prominent.

Vomer (Fig. 8). The vomer is arrow-shaped; its lateral arms are short and its posterior portion is very long and needle-like. Vomerine teeth absent.

Parasphenoid (Fig. 8). The anterior portion of the parasphenoid is very slender, bifid, and embedded in the posterior portion of the vomer.

Foramina for cranial nerves (Fig. 8). The foramen for the optic nerve is very long, bordered anterodorsally and anteroventrally by the orbitosphenoid, posterodorsally by the pterosphenoid, and posteroventrally by the parasphenoid. The foramen for the trigeminofacial nerves is roughly ovoid, has less than half the length of the optic foramen, and is bordered anteriorly and dorsally by the pterosphenoid, anteroventrally by the parasphenoid, and posteriorly and posteroventrally by the prootic. The sphenotic does not contribute to the trigeminofacial foramen. The trigeminofacial foramen is not divided by an osseous trabecula, as occurs in other heptapterids, but is constricted, forming an anterior region (through which pass the oculomotor nerve, and the trigeminal maxillary and mandibulary nerve trunks) and a posterior region (through which exit the cutaneous and hyodeomandibular nerve trunks). A broad trabecula, formed by extensions of the pterosphenoid and parasphenoid separate the optic and trigeminofacial foramina. The walls of the orbitosphenoid and pterosphenoid are mostly solid, but have several small foramina close to the optic and trigeminofacial foramina. The hyomandibular facet is well defined, and is located on the ventral portion of the cranium between the sphenotic and the lateral rim of the pterotic.

Lower jaw and related structures (Figs. 9 and 10). The dentary has a very robust overall appearance, with a smooth contour in dorsal profile, and without any noticeable anterior projection. The dentigerous portion of the dentary has about eight irregular rows of small viliform teeth. The dentary possesses a very wide tunnel running along its ventral portion and eight conspicuous openings that together serve for the passage of the main preoperculomandibular laterosensory canal and its secondary branches. The first opening is small, situated at the mesoventral margin, and serves for the exit of the pm1 branch. The second opening is large, situated lateroventral to the anterior portion of the first one-third of the dentary, and serves for the exit of the pm2 branch. The third opening is large, situated lateroventral to the posterior portion of the first third of the dentary, adjacent to the opening for the pm 2 branch, and serves for the exit of the pm 3 branch. The fourth opening is large, situated mesoventral to the end of the first one-third of the dentary, and serves for the exit of the pm4 branch. The fifth opening is large, situated lateroventral to the anterior portion of the second third of the dentary, and serves for the exit of the pm5 branch. The sixth opening is large, situated ventral to the posterior portion of the second third of the dentary, and serves for the exit of the pm6 branch. The seventh opening is large, situated ventral to the posterior one-third of the dentary, and serves for the exit of the $\mathrm{pm} 7 \mathrm{branch}$. The eighth is large, situated at the posterior extremity of the dentary, and serves for the exit of the main preoperculoman- 
dibular laterosensory canal. The coronomeckelian bone is large and triangular in shape. The ascending portion of Meckel's cartilage is long, and reaches to the upper border of the coronoid process. The ascending portion of Meckel's cartilage is not fragmented and perpendicular to its main axis, and its medial surface is slightly concave. The articular process of the anguloarticular is curved and well delimited.

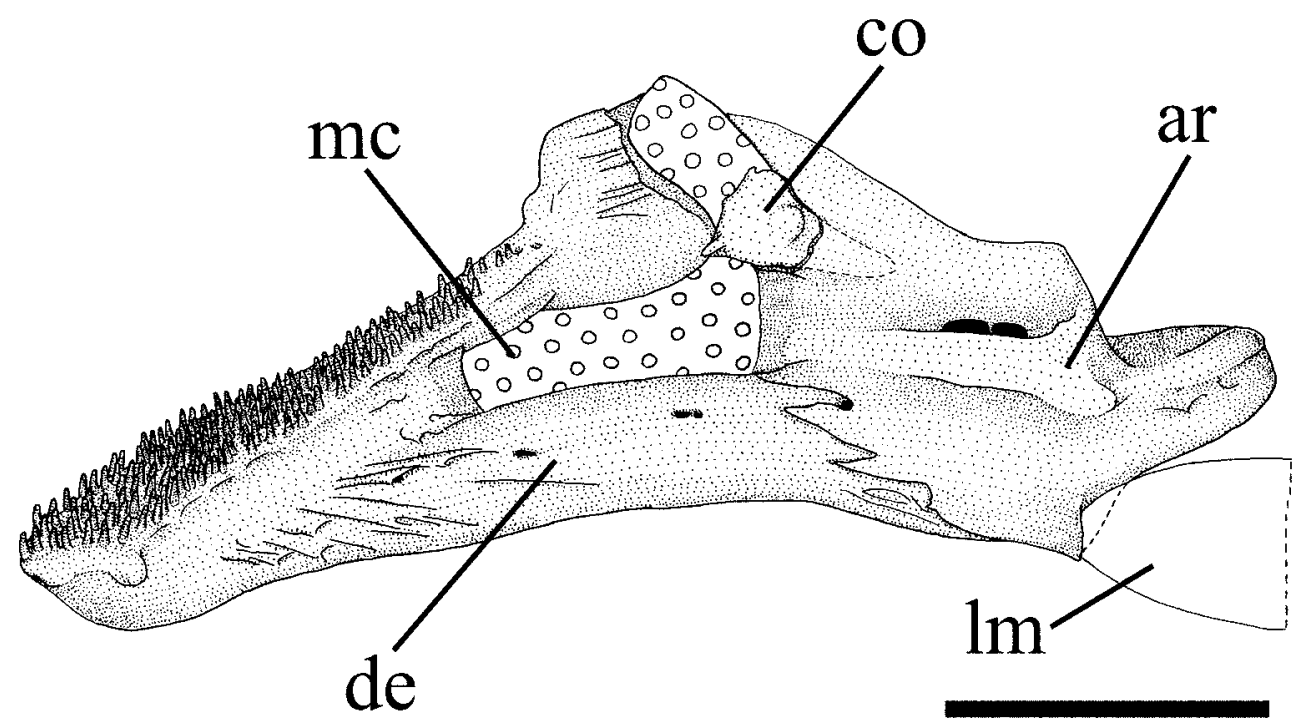

FIGURE 9. Right lower jaw of Rhamdella cainguae, LIRP 3045, male, 149.9 mm SL, paratype. Mesial view. Scale bar $=3 \mathrm{~mm}$.

Suspensorium and opercular series (Fig. 11).

Entopterygoid (Fig. 11). The entopterygoid is a thin plate roughly quadrangular in shape; its anterior and posterior margins are attached ligamentously to the lateral process of the vomer and to the anterior margin of the metapterygoid, respectively; its lateral surface is tightly attached to the lateral ethmoid. The splint-like ectopterygoid that originates as a mineralization of a ligament (=tendon bone), such as seen in the pimelodine Parapimelodus valenciennesi ("ectopterygoid type 1" sensu Arratia 1992: 65, fig. 36A), is absent.

Metapterygoid (Fig. 11). The metapterygoid is roughly quadrangular, and its size is about twice that of the entopterygoid. This bone is remote from the hyomandibula and its medial surface is largely smooth, without process or keel. The dorsal border of the metapterygoid is concave. The posteroventral border of the metapterygoid is broadly attached to the quadrate dorsally via a dentate suture, medially via a medium-sized cartilaginous block, and ventrally via a lap joint with the anterodorsal process of the quadrate.

Quadrate (Fig. 11). The quadrate is roughly rectangular in shape and very long (nearly as long as the hyomandibula), and has two separated articular facets (the anterior facet is for the metapterygoid and the posterior facet is for the hyomandibula). The anterior facet of the quadrate bears a conspicuous and long anterodorsal process that covers the ventrolateral border of metapterygoid. The quadrate has a pedunculate aspect defined by a shallow concavity along its free dorsal margin. The quadrate is firmly attached to the hyomandibula dorsally and ventrally by means of dentate sutures with an intervening medium-sized cartilaginous block. The anterior portion of the quadrate is pierced by two adjacent foramina, the posteriormost of which is much larger, immediately posterodorsal to the articular head for anguloarticular. Posteriorly the quadrate has a foramen for the entrance of the mandibular ramus of the hyoideomandibular nerve trunk (mfen) ("sympletic canal" of Lundberg and McDade 1986: 14, fig. 9), near its articulation with the hyomandibula. There is a deep fossa on the ventral surface of the quadrate behind the articular condyle. 


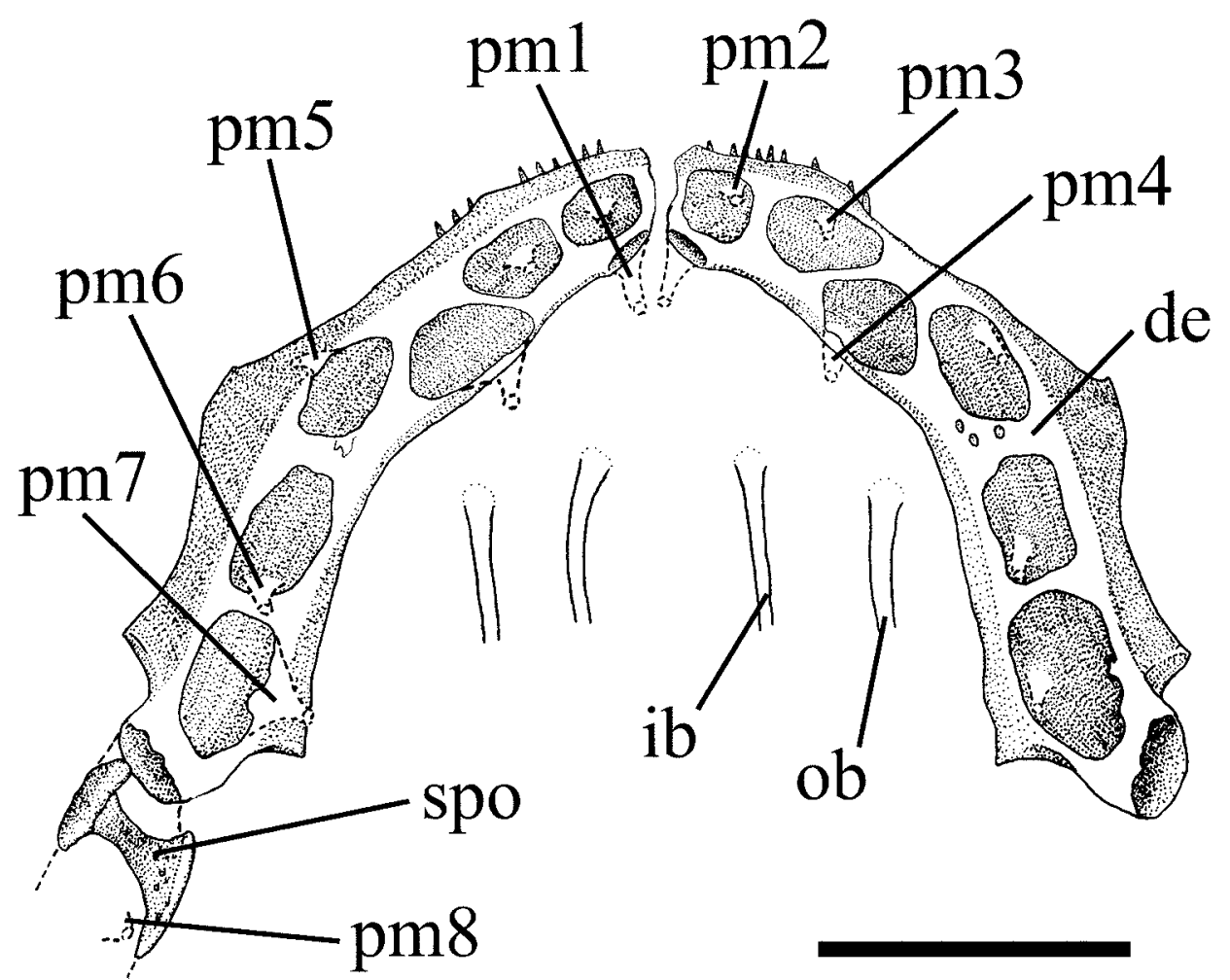

FIGURE 10. Lower jaws of Rhamdella cainguae, LIRP 3045, male, $149.9 \mathrm{~mm}$ SL, paratype. Ventral view. Scale bar $=5$ $\mathrm{mm}$.

Hyomandibula (Fig. 11). The hyomandibula is slender, with a smooth anterodorsal margin devoid of any distinct bony outgrowths or processes. The lateral surface of the hyomandibula is mostly smooth, with no discernible process or crest for the insertion of the levator arcus palatini muscle. The posterodorsal hyomandibular process for the insertion of the levator operculi muscle is triangular and large. The hyomandibula bears a short tunnel across its lower portion, the hyodeomandibular canal $(\mathrm{hmc})$ ("facial canal" of Lundberg and McDade 1986: 14, fig. 9), that serves for the passage of the hyodeomandibular nerve trunk. That nerve trunk enters the hmc through a foramen at the medial wall of the hyomandibula (hmen) at the middle of the bone and near its anterior edge ("medial foramen of facial canal" of Lundberg and McDade 1986: 14). The hyodeomandibular nerve trunk runs a short distance inside the hyomandibula across the hmc, and exits through a foramen (hmex) at the lower lateral wall of the hyomandibula, at the level of the interopercular-opercular joint ("lateral foramen of facial canal" of Lundberg and McDade 1986: 14). Near this foramen the hyodeomandibular nerve trunk splits into the mandibular and hyoid rami. The mandibular division extends forward to the quadrate, being laterally exposed for a short distance, and re-enters the suspensorium through the foramen for the mandibular ramus of the hyodeomandibular nerve trunk (mfen) (see description above). The hyoid division is ventrally oriented, being exposed laterally for a very short distance, and re-enters the suspensorium via an opening at the hyomandibula-preopercle joint near the lower corner of the hyomandibula (just below the hmex), the foramen for the entrance of the hyoid ramus (hfen) ("mandibular nerve foramen" of Lundberg and McDade 1986: 14). The hyomandibula is also pierced by a small and elliptical opening close to its midlength, on the upper portion of the hyodeomandibular nerve trunk canal $(\mathrm{hmc})$, adjacent to the foramen for the entrance of this nerve trunk (hmen). This foramen serves for the passage of the nerve trunk that innervates the infraorbital laterosensory canal, and is consequently called the infraorbital foramen (if). 


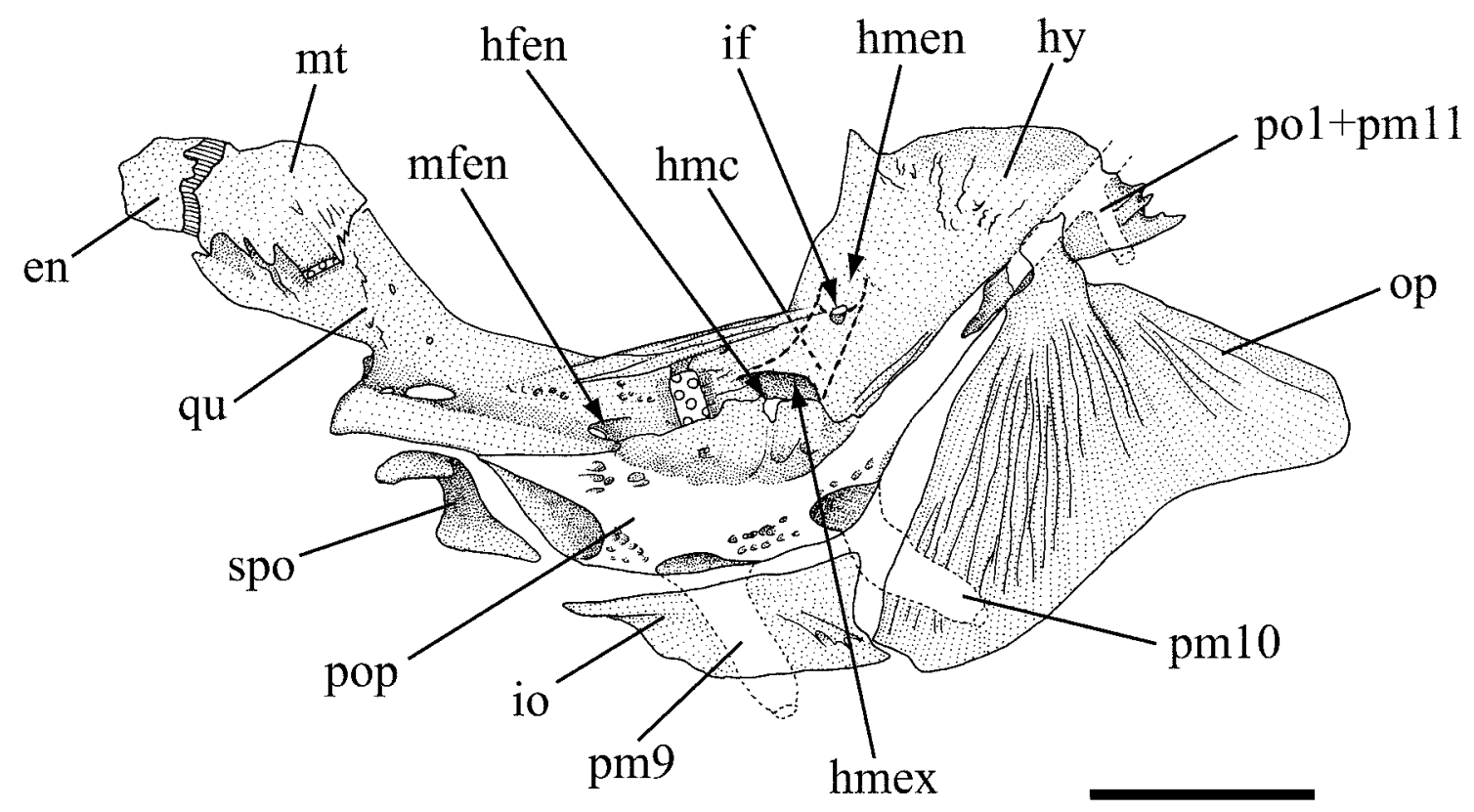

FIGURE 11. Left suspensorium and opercular series of Rhamdella cainguae, LIRP 3045, male, 149.9 mm SL, paratype. Lateral view. Scale bar $=5 \mathrm{~mm}$.

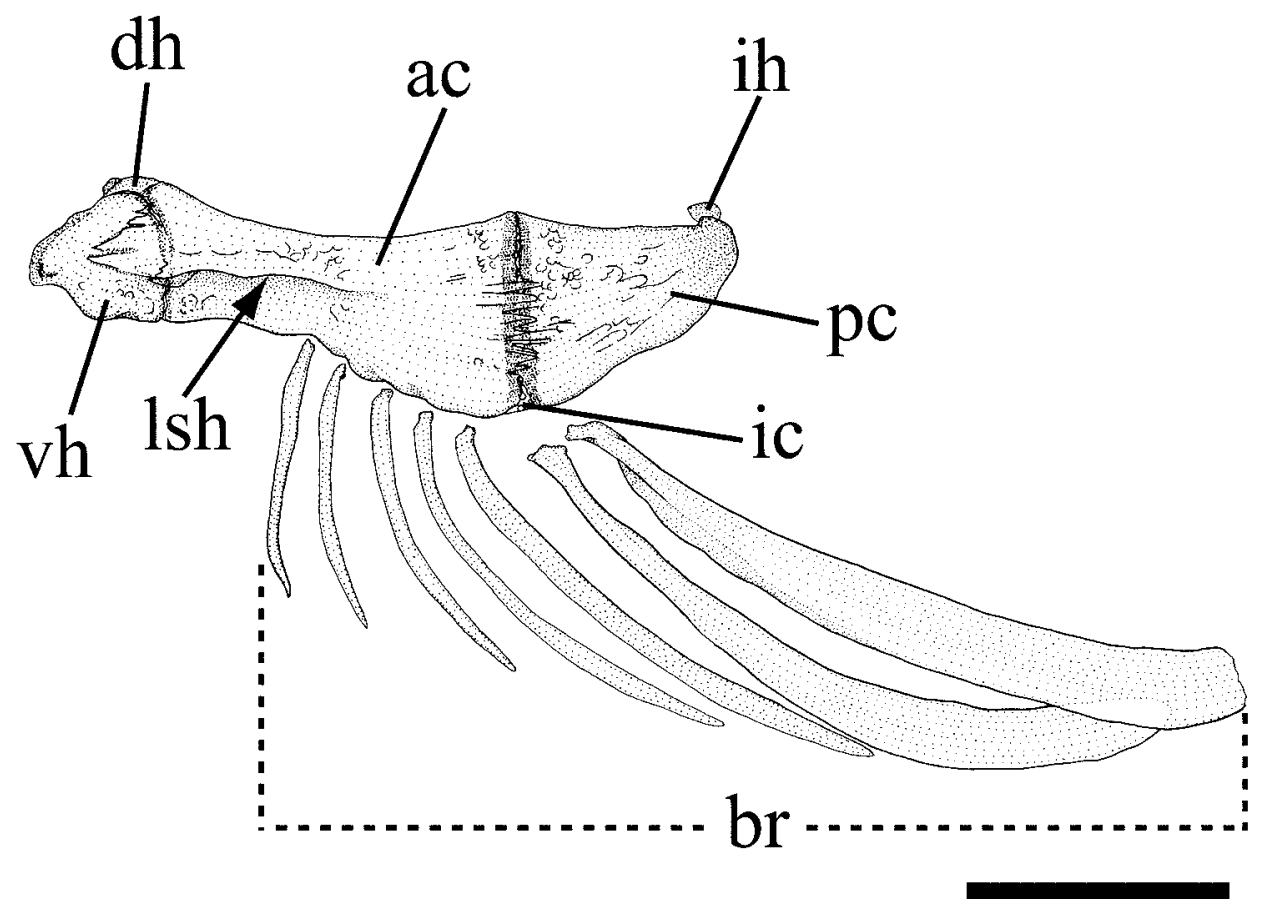

FIGURE 12. Left hyoid arch of Rhamdella cainguae, LIRP 3045, male, $149.9 \mathrm{~mm}$ SL, paratype. Lateral view. Scale bar $=5 \mathrm{~mm}$.

Preopercle and subpreopercle (Fig. 11). The preopercle is concave, and its upper and lower limbs have approximately the same length. The upper limb is truncated at the opercle-hyomandibular joint. The preopercle bears four openings for the passage of the main preoperculomandibular laterosensory canal and for the exit of its secondary branches. The first opening is very large, situated at the anteriormost extremity of the preopercle, and serves for the passage of the main preoperculomandibular laterosensory canal. The second opening is a large ventral slit, situated at the middle of the lower limb of the bone above the interopercle and below the cartilaginous block between the quadrate and hyomandibula, and serves for the exit of the pm9 branch. 
The third opening is medium-sized, situated ventral to the midpoint between the lower and upper preopercle limbs above the interopercular-opercular contact point, and serves for the exit of the pm10 branch. The fourth opening is small, situated lateral at the posteriormost and dorsalmost extremity of the opercle just ahead of the level of the hyomandibula-opercle joint, and serves for the passage of the main preoperculomandibular laterosensory canal. A wide tubular subpreopercle ossicle surrounds the laterosensory canal between the preopercle and the mandible. The region of the preoperculomandibular laterosensory canal between the posteriormost tip of the preopercle, at the level of the hyomandibular condyle for the opercle, and the point of origin of the po1+pm11 branch, is weakly ossified, lacking any conspicuous bony tubule (sometimes called suprapreopercle).

Opercle (Fig. 11). The opercle is triangular in shape, with its lateral surface largely flat, with striae and longitudinal grooves but with no conspicuous crest and fossae for accommodation of the levator operculi muscle. The opercle is high, with a depth at its anterior edge noticeably greater than its width along its dorsal margin, and with the angle between the anterior and dorsal margins about $90^{\circ}$. The anterior and dorsal margins of the opercle are nearly straight, with its dorsal margin lacking any distinguishable mesially sloped lamina and with its posterior portion straight in relation to its entire length, but not distinctly angled ventrally. The posterior edge of the opercle is concave, rounded posterodorsally.

Interopercle (Fig. 11). The interopercle is approximately quadrangular, with its width about twice its depth. The posterior margin of the interopercle has a shallow concavity but does not form a perfect articulation for the anteroventral angle of the opercle.

Hyoid arches (Figs. 12 and 13). The dorsal hypohyal has a short dorsal process above the urohyal. The region between the dorsal portions of the dorsal hypohyal and the anterior ceratohyal has a longitudinal foramen. The lateral surface of the branchiostegal arch is convex, with a conspicuous shelf extending from the posterior portion of the ventral hypohyal to about the midlength of the anterior ceratohyal. The medial surface of the branchiostegal arch is deeply excavated. The anterior and posterior ceratohyals are joined via a synchondral joint and a pronounced dentate lateral suture. The dentate suture between the medial surfaces of these bones is absent. The lowermost limit of the inter-ceratohyal cartilage is aligned with the ventral edge of the bony portion of the ceratohyals, rather than extending posteriorly along the ventral border of the posterior ceratohyal. The interhyal is nodular, and completely ossified. Seven branchiostegal rays are present, with the first five articulated on the anterior ceratohyal, the sixth on the inter-ceratohyal joint, and the seventh on the posterior ceratohyal.

Urohyal (Fig. 13). The urohyal is triangular in dorsal view. The urohyal possesses a dorsal keel longer than its horizontal portion. Its posterior limit reaches the transverse line through the anterior limit of the basibranchials 3. The anterior limbs of the urohyal are united in front of a ventral midline foramen.

Branchial arches (Fig. 14).

Basibranchials (Fig. 14). The basibranchial 1 is absent. The basibranchials 2 and 3 are united to each other forming a long rod, the anterior tip of which lodges on the dorsal surface of the urohyal keel and the posterior tip is situated just in front of the anteromedial region of both hypobranchials 3 . The ossification of basibranchial 2 is nearly as long as the bony portions of basibranchial 3 and hypobranchial 1 . The basibranchial 4 is completely cartilaginous, composed of a hexagonal plate-like dorsal portion and a rod-like ventral portion. The basibranchial 4 is bordered anteriorly by hypobranchials 3, laterally by the cartilaginous heads of ceratobranchials 4, and posteriorly by the cartilaginous heads of ceratobranchials 5 .

Hypobranchials (Fig. 14). Three hypobranchials are present (the cartilaginous head of ceratobranchial 4 was identified as a hypobranchial by Lundberg and McDade 1986: 15, fig. 10D). The hypobranchial 1 is slightly elongate, largely ossified, and has cartilage only at its proximal and distal extremities. The hypobranchial 1 has a discrete, ventrally-oriented uncinate process on its anterodistal portion. The hypobranchial 2 is elongate, approximately rectangular, largely ossified, and has a continuous cartilaginous sheet along its entire posterior border. The hypobranchial 2 possesses a broad, anterolaterally-oriented process on its anterodistal 
region. The hypobranchial 3 is totally cartilaginous, roughly rectangular, and closely positioned relative to its counterpart, and has its anterolateral vertice distinctly anterolaterally projected. The hypobranchial 4 is absent.

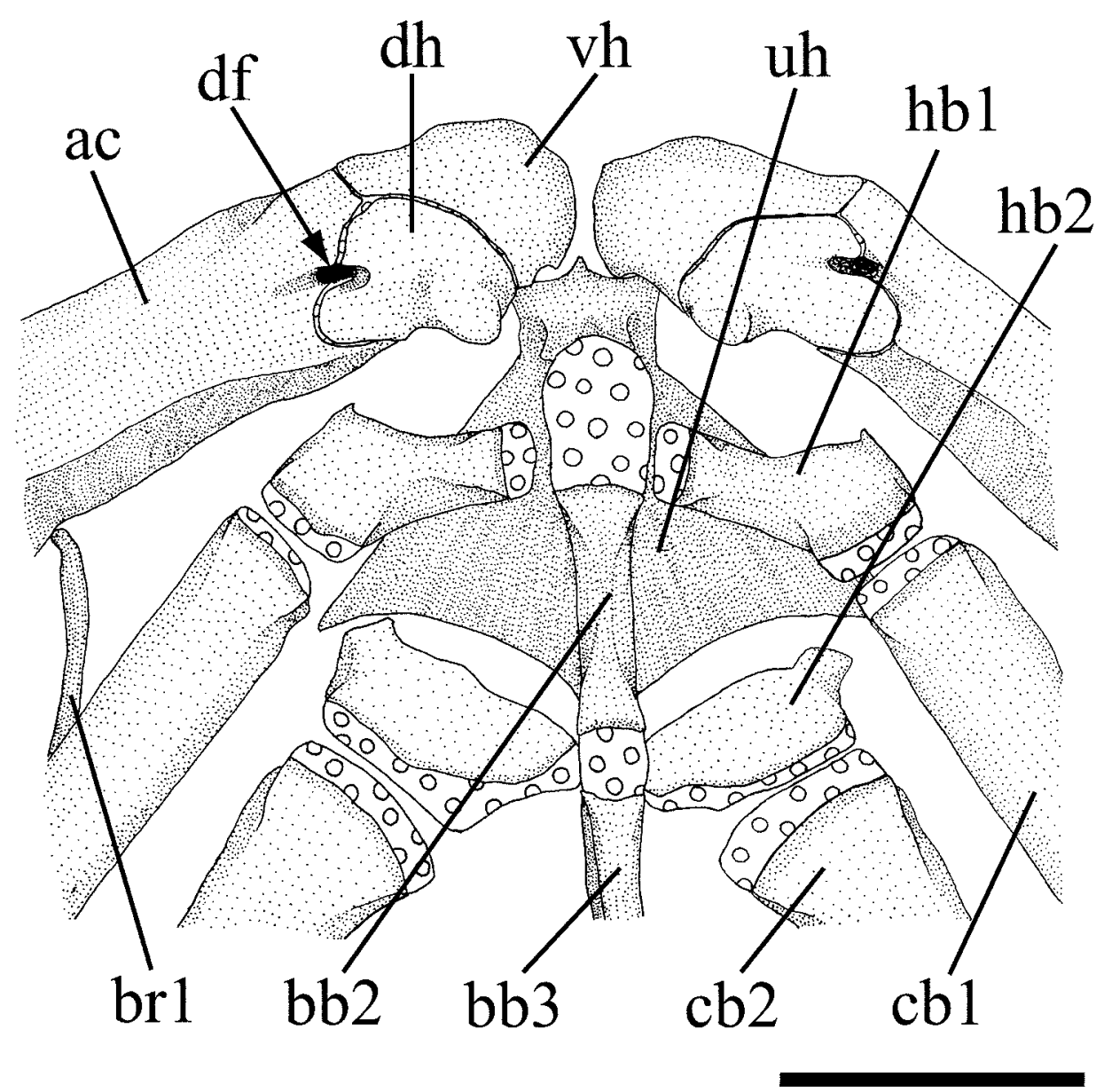

FIGURE 13. Anterior portion of hyoid arches and lower gill arches of Rhamdella cainguae, LIRP 3045, male, 149.9 $\mathrm{mm}$ SL, paratype. Dorsal view. Scale bar $=3 \mathrm{~mm}$.

Ceratobranchials (Fig. 14). Five curved and mostly ossified ceratobranchials are present. The ceratobranchials have only cartilage at their extremities. The ceratobranchials 1 to 3 are distinctly wider proximally than at their midlength. The proximate cartilaginous head of ceratobranchial 4 is laterally concave, and forms an oblique angle with basibranchial 4 . The ceratobranchial 5 is expanded posteromedially to support a patch of fine conical teeth, all approximately of similar size. The distal cartilaginous head of ceratobranchial 5 is distinctly longer than the distal cartilaginous heads of the more anterior ceratobranchials.

Epibranchials (Fig. 14). Five epibranchials are present, the first four are rod-like and largely ossified except at their extremities and the fifth epibranchial is nodular and completely cartilaginous. The anterior and posterior margins of epibranchial 1 are mostly smooth and devoid of noticeable crests or processes. The anterior and posterior margins of epibranchial 2 are mostly smooth except for a low posterior crest. The epibranchial 3 has a long, narrow posterior uncinate process of constant width which overlaps epibranchial 4 . The epibranchial 4 has broad anterior and posterior crests. The epibranchial 5 is nodular and cartilaginous, and is situated medial to the distal cartilaginous head of ceratobranchial 4, and covers the distal cartilaginous head of ceratobranchial 5. Given its close association to the ceratobranchial 4 and the different shape and structure it is quite possible that this element is not a true epibranchial 5 but rather a neomorphic structure (neomorphic cartilaginous nodules occur in branchial arches of various catfishes; pers. obs.). 


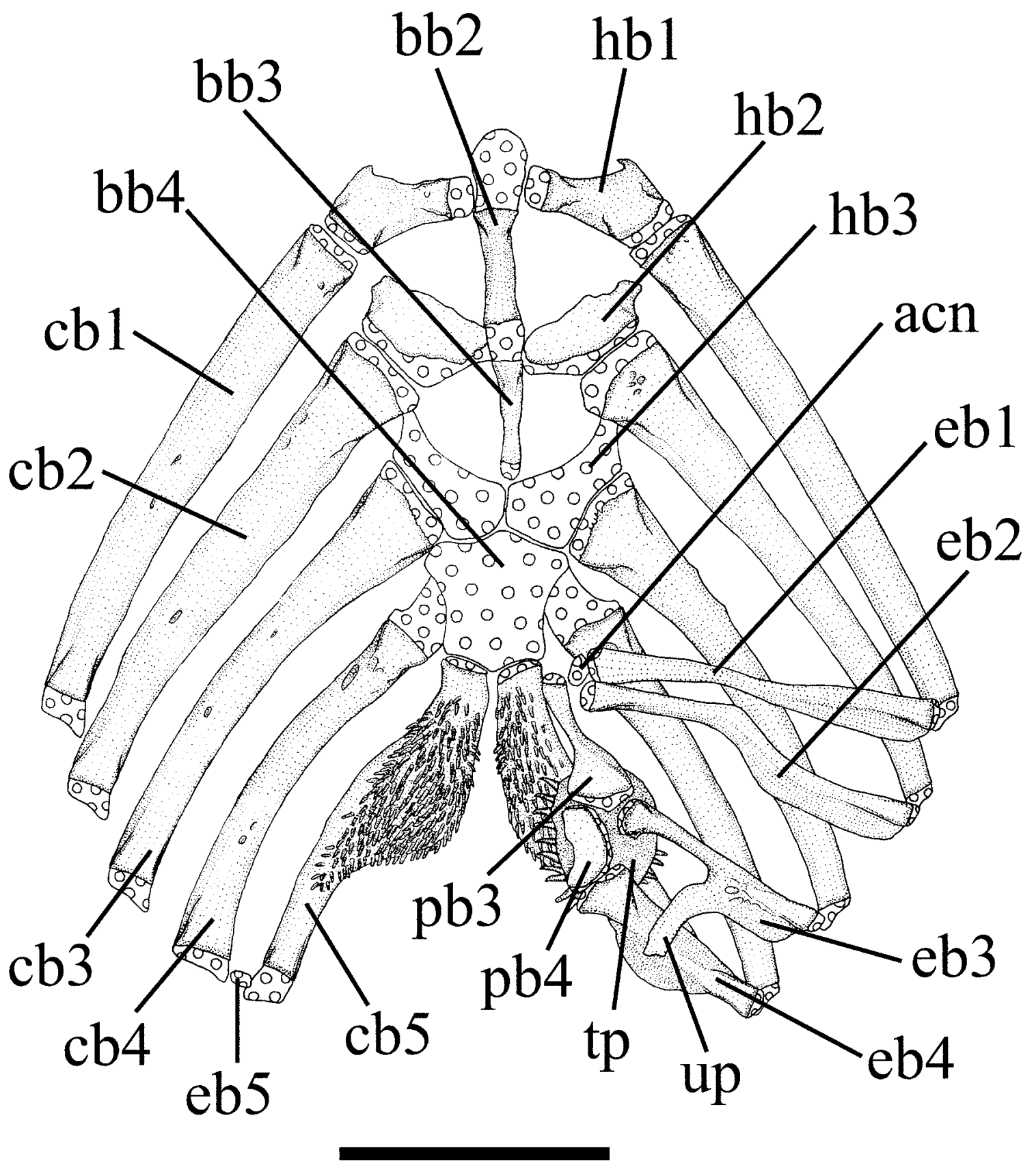

FIGURE 14. Gill arches of Rhamdella cainguae, LIRP 3045, male, $149.9 \mathrm{~mm}$ SL, paratype. Dorsal view. Gill rakers and dorsal elements of left gill arches not shown. Scale bar $=5 \mathrm{~mm}$.

Pharyngobranchials (Fig. 14). The pharyngobranchials 1 and 2 are absent. The pharyngobranchials 3 and 4 are present. The pharyngobranchial 3 is an ossified and elongate rod, with a shallow lateral crest, and with the medial margin smooth and lacking of a crest and the posterior tip distinctly expanded. The pharyngobranchial 4 is semicircular and almost completely ossified. A neomorphic cartilaginous nodule ("pharyngobranchial 2" of Lundberg and McDade 1986: 15, figs. 10C and 16) is located near the inner tips of epibranchials 1 and 2 and the anterior tip of pharyngobranchial 3.

Tooth plate (Fig. 14). A large ovoid upper pharyngeal tooth plate is situated ventral to the posterior portion of pharyngobranchial 3, the pharyngobranchial 4, and the medial extremities of epibranchials 3 and 4 .

Supracleithrum (Fig. 8). The supracleithrum ("posttemporal" of Chardon 1968; "supracleithrum" of Lundberg 1975; and "postemporosupracleithrum" of Arratia 1987) is composed of the supracleithrum and the 
Baudelot's ligament totally co-ossified, and perhaps also the posttemporal (Fink and Fink 1981, 1996). The ventrolateral and ventromedial limbs of the supracleithrum are basally joined to each other via a strong ligament, delimiting a canal to the ascending limb of the cleithrum. The ventromedial limb is distinctly shorter than the ventrolateral limb, does not contact the gas bladder, and articulates with the anterolateral ovoid facet of the anterior branch of transverse process 4 (Fig. 15). The proximal extremity of Baudelot's ligament is completely ossified, and is ligamentously attached to the basioccipital and exoccipital.

Vertebral column. The number of total vertebrae is 43 (2) or 44 (1). The neural spines of the vertebrae extend dorsally, but do not reach the skin. The neural spines of vertebrae 4 through 11 are bifid distally but are not expanded or notched distally. The basal radials of the dorsal fin articulate on the neural spines of vertebrae 4 through 11. Nine pairs of ribs are associated with parapophyses of vertebrae 6 to 14. The first complete (i.e. not bifid) hemal spine is located on vertebrae 16 (1) or 17 (2). The rib-bearing parapophysis are long and devoid of any specific area for articulation of ribs. The distal extremities of the pleural ribs are tapered. The neural and hemal spines of the caudal vertebrae are mostly straight, with no conspicuous projection, sloped at $45^{\circ}$ relative to the vertebral column.

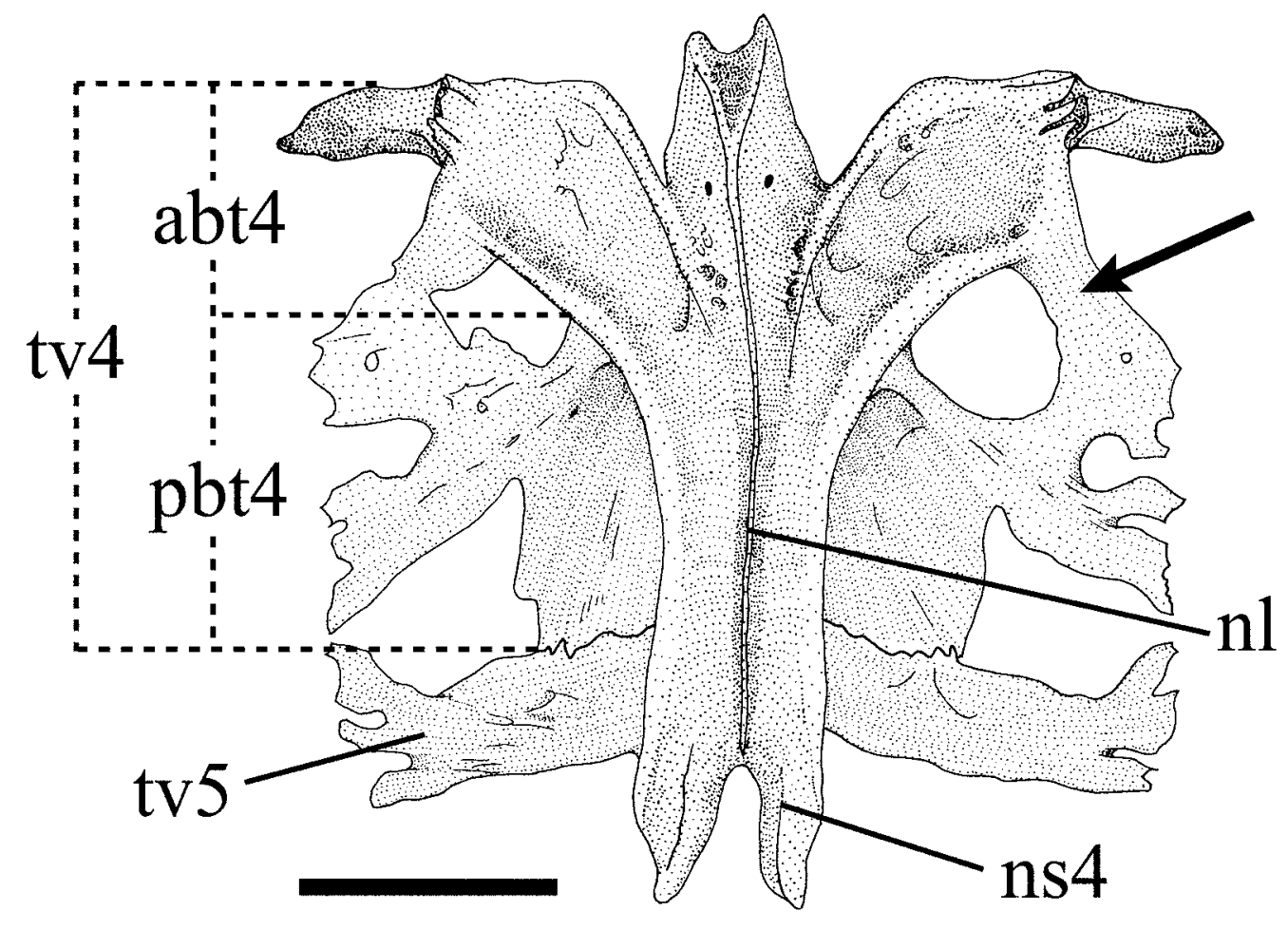

FIGURE 15. Anterior vertebrae of Rhamdella cainguae, LIRP 3045, male, 149.9 mm SL, paratype. Dorsal view. Anterior at top. Arrow indicates the osseous bridge joining anterior and posterior branches of the transverse process 4 . Scale bar $=5 \mathrm{~mm}$.

Complex vertebra and associated structures (Fig. 15). The centrum 1 is an autogenous disc-like element, firmly attached to complex vertebra via connective tissue and ventral sutures. The centra of the complex vertebra (vertebrae 2 to 4 ) and vertebra 5 are sutured to each other. There are no sutures between centra of vertebrae 5 and 6 . The bases of the transverse process of vertebrae 5 and 6 do not contact each other. The dorsal margin of the vertical lamina of the complex vertebra is straight or slightly concave. The neural spine of vertebra 4 is sloped posteriorly, and completely covers in dorsal view the neural spine of vertebra 5 . The transverse 
process of vertebra 4 is sharply divided into anterior and posterior branches by a deep notch. The anterior branch of the transverse process of vertebra 4 is wide (laminar), and ventrolaterally oriented. The distal portion of the posterior branch of the transverse process of vertebra 4 is a wide, laterally expanded lamina, with various distal notches. The complex vertebra is long and closely associated with the lengthy gas bladder, which extends to the sixth vertebra. The anterior portion (arborescent portion) of the posterior branch of the transverse process of vertebra 4 is divided into two main arms by a conspicuous notch. The posterior portion of the posterior branch of the transverse process of vertebra 4 has the lateral border nearly parallel to the main body axis, and its posterolateral corner reaches approximately to the midlength of the transverse process of vertebra 5 . The distal extremity of the transverse process of vertebra 5 is expanded and branched. The posterior border of the anterior branch and the anterior margin of the arborescent portion of the posterior branch of the transverse process of vertebra 4 are joined to each other via a bony bridge (Fig. 15, see arrow). The ascending process of the scaphium is present and the posterior portion of the transformator process of the tripus is thick and curves medially.

Dorsal fin and associated elements. Dorsal fin elements are preceded by only one supraneural, which is small, short, and constituted by a dorsal trapezoidal lamina (the anterior nuchal plate) and a ventral triangular keel. The supraneural is firmly attached to the first basal radial. The first basal radial is expanded distally forming the median nuchal plate, which has two posterior arms delimiting the concavity where the spinelet is accommodated. The second basal radial is bifid distally, and expanded into plates at each side of the second dorsal-fin ray, composing the posterior nuchal plates. The nuchal plates are slightly ornamented dorsally. The first ray of dorsal fin (spinelet) is small and approximately triangular. The rigid basal portion of the second ray of the dorsal fin is approximately ovoid in cross section. The dorsal-fin rays are supported by seven blade-like basal radials. The basal radials 1 and 2 of dorsal fin are attached distally but are separated from each other along most of their length. The tips of the first and last basal radials of dorsal fin are situated immediately behind and ahead of neural spines of vertebrae 4 (1) or 5 (2), and 11, respectively.

Pectoral girdle and fins (Figs. 16 and 17). The dorsomedial limb of the cleithrum is smooth, without a distinct area on its posterior surface to accommodate epaxial muscle fibers. The postcleithral process is slender, pointed, long (its extremity extending to about middle of rigid part of pectoral-fin ray 1), and bears small ornamentations. The mesocoracoid arch is a slender ring, either complete or incomplete. The ventral portion of the pectoral girdle is formed by a wide horizontal bridge composed of the two cleithra, that are ligamentously united to each other, and by the coracoid portion of the posterior complex bone of the pectoral girdle (composed of the scapula, coracoid, and mesocoracoid) that is tightly joined to its antimere via an interlocking symphysis formed by four sutural dentations. The posteroventral process of the coracoid keel is narrow distally and does not reach the skin surface, with its posterior border concave giving it a spine-like aspect. The two rod-like proximal radials are present and lack lateral crests and processes ("hook-like process" of Mo 1991) on the dorsal and ventral surfaces of their proximal portions, and have the proximal and distal tips covered by cartilaginous caps. The proximal radial 1 is slightly shorter than proximal radial 2. Five distal radials are present, with the first three largely ossified (drc, dr1, and dr2) and the last two completely cartilaginous (dr3 and dr4). The first distal radial has a globose overall shape and is formed by several distinct centers of ossification. The first distal radial is located between the posterior cavity of the spine base and the bases of the first two soft rays. The distal radials decrease in size posteriorly. The two basal thirds of first ray of the pectoral fin are strongly ossified and rigid, with segmentation barely discernable, forming a pungent spine. The distal third of first pectoral-fin ray is weakly ossified, flexible, and segmented, with the tip surpassed by the tip of second pectoral-fin ray (first branched). The pectoral spine is slightly convex dorsally. The outer margin of the rigid portion of the pectoral-fin ray is almost entirely covered by 29-39 conspicuous, perpendicularly-oriented dentations. The inner margin of the rigid portion of the pectoral-fin ray is covered from its base to a point little beyond its midlength, with 13-14 conspicuous, perpendicularly-oriented and posteriorly curved dentations. 


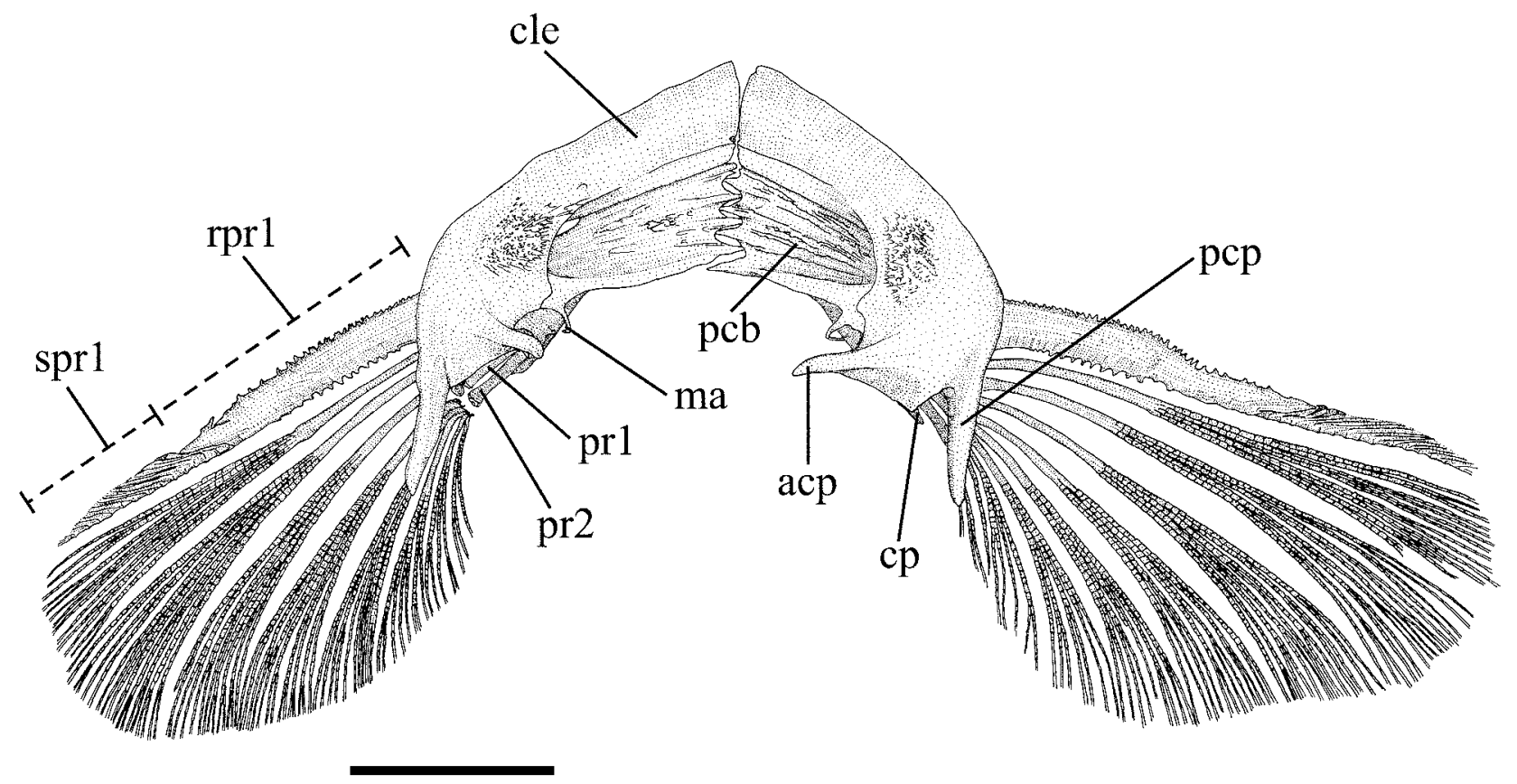

FIGURE 16. Pectoral girdle and fins of Rhamdella cainguae, LIRP 3045, male, 149.9 mm SL, paratype. Dorsal view. Scale bar $=10 \mathrm{~mm}$.

Pelvic girdle (Fig. 18). The basipterygium is slightly arched and excavated on its dorsal and ventral surfaces, respectively. There is no pelvic splint or radials. The external and internal anterior processes (anterolateral and anteromedial arms, respectively) are long. The anterolateral arm becomes progressively narrower towards its tip, being most slender at its distal osseous tip, and it has a small, cylindrical distal cartilage not fused distally to its counterpart. The anteromedial arm is slightly shorter than the anterolateral arm, much wider basally than distally, narrowing towards the tip, and meets its counterpart via a short symphysis. The basipterygium has a prominent lateral process and a long angular posterior process. The lateral and medial/ posterior basipterygium cartilages are distinctly separated from each other. The medial cartilages of the basipterygia are also separated from each other. The bony portion of the posterior process of the basipterygium is long, about 0.3 times of the main body of the basipterygium. The cartilaginous portion of the posterior process is also long, almost as long as the bony portion of the posterior process, and is aligned along the lateral margin of the bony portion of the posterior process of the basipterygium. The lateral margin of the posterior process is slightly medially aligned relative to its longitudinal axis. The first pelvic-fin ray is slightly depressed, and not conspicuously expanded laterally. The last pelvic-fin ray is branched. The point of insertion of the first pelvicfin ray on the basipterygium is situated along the vertical through the fifteenth vertebral centrum.

Adipose fin. The origin and end of base of adipose fin is on the vertical through vertebral centra 16 and 38 (1), 16 and 39 (1), and 17 and 38 (1), respectively.

Anal fin and associated elements. The posteriormost rays of the anal fin are all branched. No accessory element in front of the medial portion of basal radial 1 of the anal fin was observed. The anal-fin rays are supported by 15 blade-like basal radials. The tips of the first and last basal radials are situated immediately posterior of and anterior to hemal spines of vertebrae 19 and 29, respectively. 


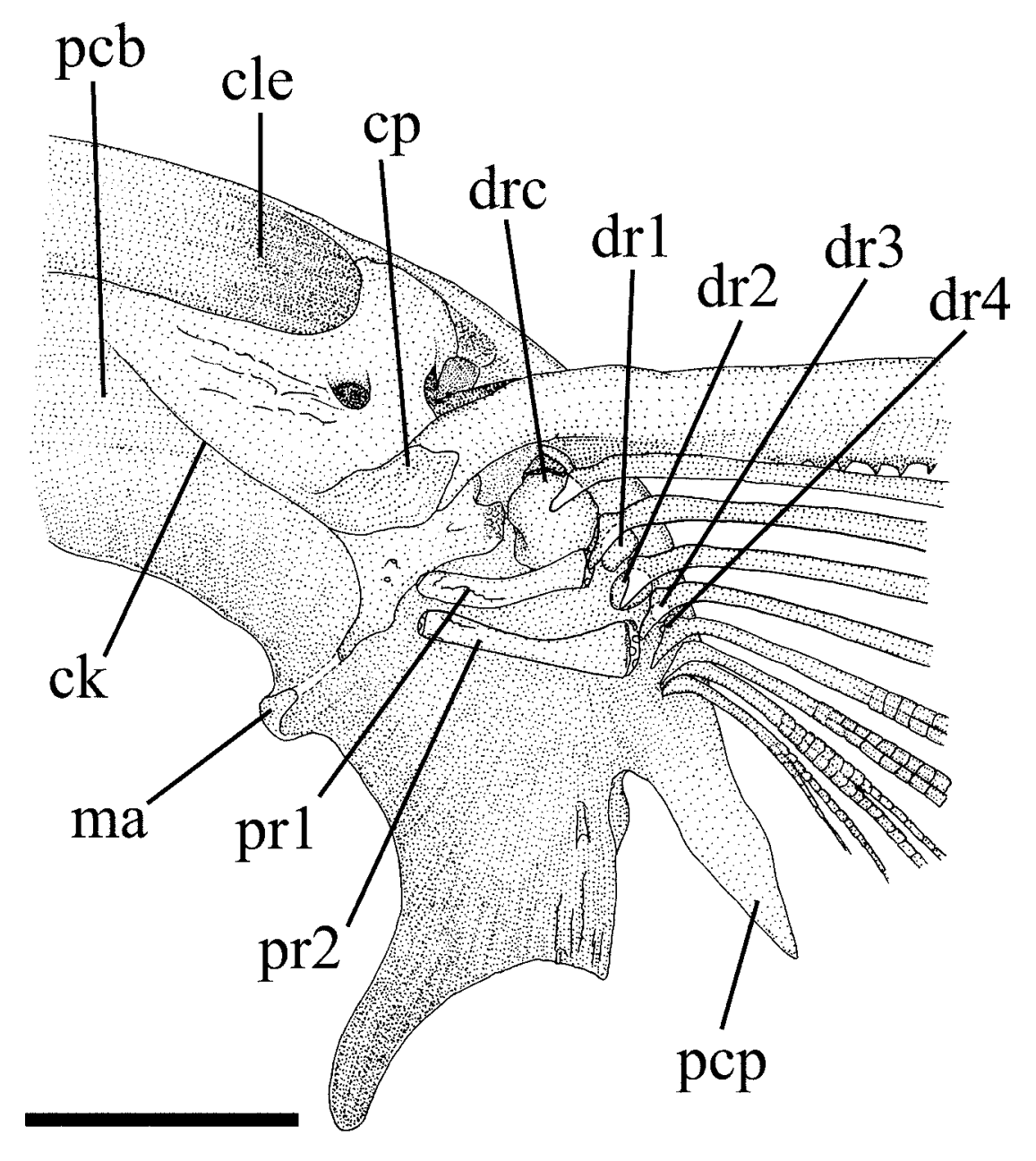

FIGURE 17. Basal region of left pectoral fin and proximate portions of pectoral girdle of Rhamdella cainguae, LIRP 3045, male, $149.9 \mathrm{~mm} \mathrm{SL}$, paratype. Ventral view. Scale bar $=5 \mathrm{~mm}$.

Caudal skeleton (Figs. 19 and 20). The hypurals 1 and 2 are completely co-ossified into a single ventral caudal plate, without any vestige of a suture line. The parhypural runs close to, but clearly separated from, the inferior margin of ventral caudal plate. The hypurals 3, 4 and 5 are completely co-ossified into a single dorsal caudal plate, without any vestige of a suture line. The uroneural is present as a long blade that is not co-ossified to the dorsal margin of hypural 5. The dorsal and ventral hypural plates are distinctly separated from each other except for their bases. The hypurapophysis and secondary hypurapophysis are fused to form a wide horizontal plate, the complex hypurapophysis, that extends to the base of hypural 2 (hypurapophysis "type C" of Lundberg and Baskin 1969). The ventral margin of the complex hypurapophysis is straight, without any perceptible process. The complex hypurapophysis is pierced by a foramen for the passage of the dorsal branch of the caudal artery, just behind the PU1+U1 centrum. The dorsal caudal plate, composed of uroneural and complex dorsal hypural plate (including hypurals 3, 4, and 5), bears two unbranched and seven branched rays, with the dorsalmost ray attached to the uroneural and the remaining rays to the complex dorsal hypural plate. The ventral caudal plate, consisting of the parhypural and complex ventral hypural plate (including hypurals 1 and 2), bears eight branched and one unbranched rays [with six branched rays attached to the complex ventral hypural plate, and two branched rays and one unbranched ray (the lowermost) attached to the parhypural (2)] or eight branched and two unbranched rays [with seven branched rays attached to complex ventral hypural plate, and one branched ray and two unbranched rays (the lowermosts) attached to the parhypural (1)]. The bases of the middle caudal-fin rays (the lowermost ray of the dorsal caudal-fin lobe and the uppermost ray of 
the ventral caudal-fin lobe) articulate directly to the caudal plates. The middle caudal-fin rays are branched and without marginal expansions, such as the other caudal-fin rays.

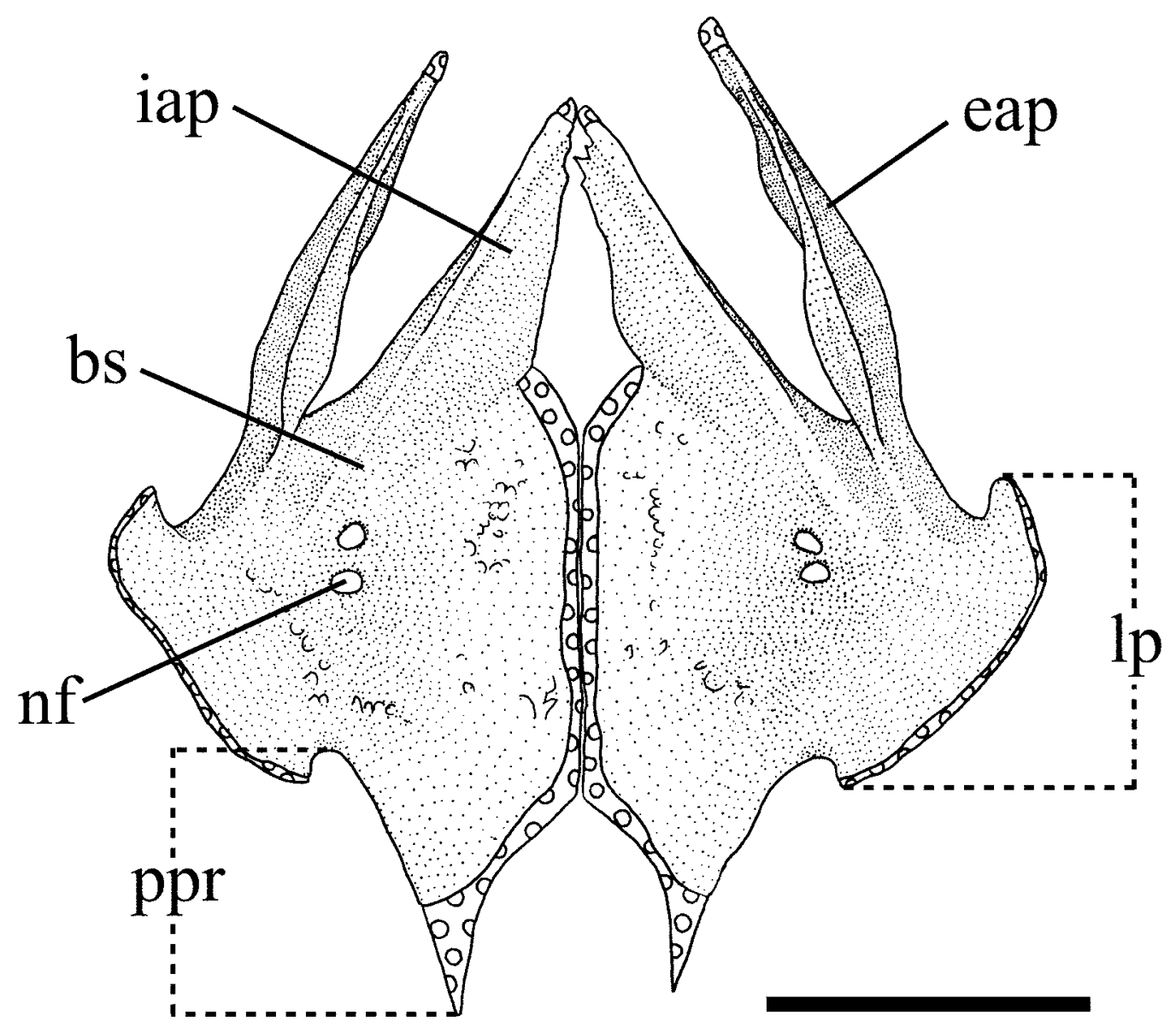

FIGURE 18. Pelvic girdle of Rhamdella cainguae, LIRP 3045, male, 149.9 mm SL, paratype. Dorsal view. Scale bar = $5 \mathrm{~mm}$.

Laterosensory system (Figs. 3-5, 7, 8, 10, and 11). Most of the head laterosensory canals have simple (non-dendritic) tubes ending in very small pores. The branches of the laterosensory canals are usually short and bear a single pore at their distal extremities unless noted otherwise. The diameter of the head laterosensory canals is approximately constant throughout. The pore diameter is approximately 0.1 times the greatest width of the posterior nare.

The supraorbital laterosensory canal is connected to the infraorbital laterosensory canal via its s2 branch anteriorly, and to the optic and infraorbital laterosensory canals posteriorly (Figs. 3, 4, and 7). The supraorbital laterosensory canal bears seven supraorbital branches (s). The s1 branch is anteriorly directed and originates from the anteriormost opening of nasal bone. The s1 pore is located anteromedial to anterior nare. The s2 branch is posteriorly oriented, originates from the dorsolateral opening of the anterior half of the nasal bone, and bears a single pore at its distal extremity that is shared with the i2 branch (antorbital branch) of the infraorbital laterosensory canal. The complex s2+i2 (2nd supraorbital+antorbital) pore is located approximately at midpoint between the anterior and posterior nares but distant from both nares. The s3 branch is medium-sized, laterally-oriented, and originates from the region of the supraorbital laterosensory canal between the posterior and anterior openings of the nasal and frontal, respectively. The s3 pore is located between the posterior nare and the anterior orbital rim, adjacent and posteromedial to the posterior nare. The $\mathrm{s} 4$ branch is medium-sized, posterolaterally directed, and also originates from the region of the supraorbital 
laterosensory canal between the posterior and anterior openings of the nasal and frontal, respectively. The s4 pore is located between the posterior nare and the anterior orbital rim, nearer to the orbital rim. The s5 branch and respective pore are absent. The $\mathrm{s} 6$ (epiphyseal) branch is slightly posteriorly-directed and originates from the large dorsal opening of the frontal far anterior to the epiphyseal bar. The s6 branch is fused to its counterpart at the midline of the cranium, and from the intersection arises a short posteriorly-directed branch which is either distally simple, or divided into three secondary branches, each of which bears its own pore. The s6 (epiphyseal) pore(s) is located between the eyes. The s7 (postorbital) branch is very short, situated almost above the supraorbital laterosensory canal, laterally directed, and originates from an ovoid opening at the posterodorsal portion of the frontal. The s7 (postorbital) pore is located at the anterior portion of the posterior half of the cranium just posterior of the line through the posterior orbital rim. The $\mathrm{s} 8$ (parietal) branch is posteriorly directed and originates from the small, ovoid opening at the posterodorsal surface of the frontal. The s8 (parietal) pore is located just posterior to the $\mathrm{s} 7$ pore, and its distance from the epiphyseal (s6) pore(s) is approximately equal to the distance to its antimere, so that the three pores form an equilateral triangle.

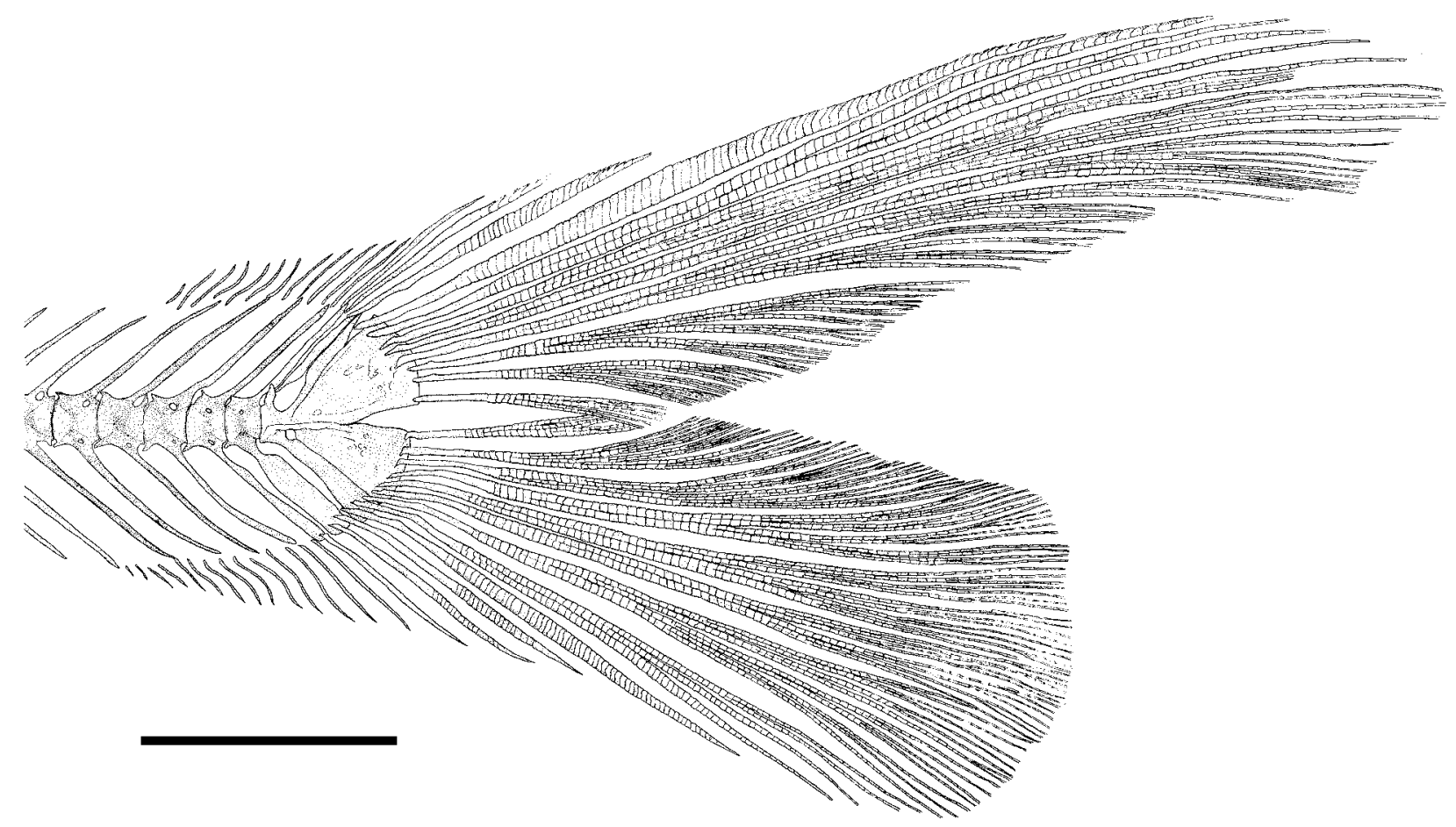

FIGURE 19. Caudal fin of Rhamdella cainguae, LIRP 3045, male, $149.9 \mathrm{~mm}$ SL, paratype. Lateral view. Scale bar $=10$ $\mathrm{mm}$.

The otic laterosensory canal is short, without pores, and continuous with posterior limits of supra- and infraorbital laterosensory canals anteriorly, and with the anterior limit of the postotic laterosensory canals posteriorly (Figs. 3, 4, and 7).

The postotic (or temporal) laterosensory canal extends from the posterior limit of the otic laterosensory canals to the anterior limit of lateral line, with three branches (Figs. 3, 4, 7, and 8). The pol branch is ventrally directed and originates from the small, ovoid opening of the anterolateral border of pterotic. The end of the pol branch is fused to the posteriormost limit of the preoperculomandibular laterosensory canal. Originating from the intersection between those canals is a short, posteriorly directed, secondary branch bearing a common pore (po1+pm11) distally. The po1+pm11 complex pore (1st postotic+last preoperculomandibular pores) is placed approximately midway between the posterior border of the orbit and the dorsalmost limit of the branchial slit. One specimen (MNRJ 23157, $153.2 \mathrm{~mm} \mathrm{SL}$ ) has separate po1 and pm11 pores on the right side of the head. The po2 (pterotic or temporal) branch is long, posteroventrally directed, and originates from the 
large opening framed by the posterolateral border of pterotic and the anterolateral margin of extrascapular. The po2 (pterotic or temporal) pore is placed close and above the posterior limit of the opercle and adjacent to the dorsal limit of the branchial slit from lateral view, and on the line crossing the middle of the orbit from dorsal view. The po3 branch is posteroventrally oriented and originates from the space between the posterolateral margin of the extrascapular and the anterolateral margin of the supracleithrum. The po3 pore is placed behind the posterior corner of the opercle, above the supracleithral pore (111).

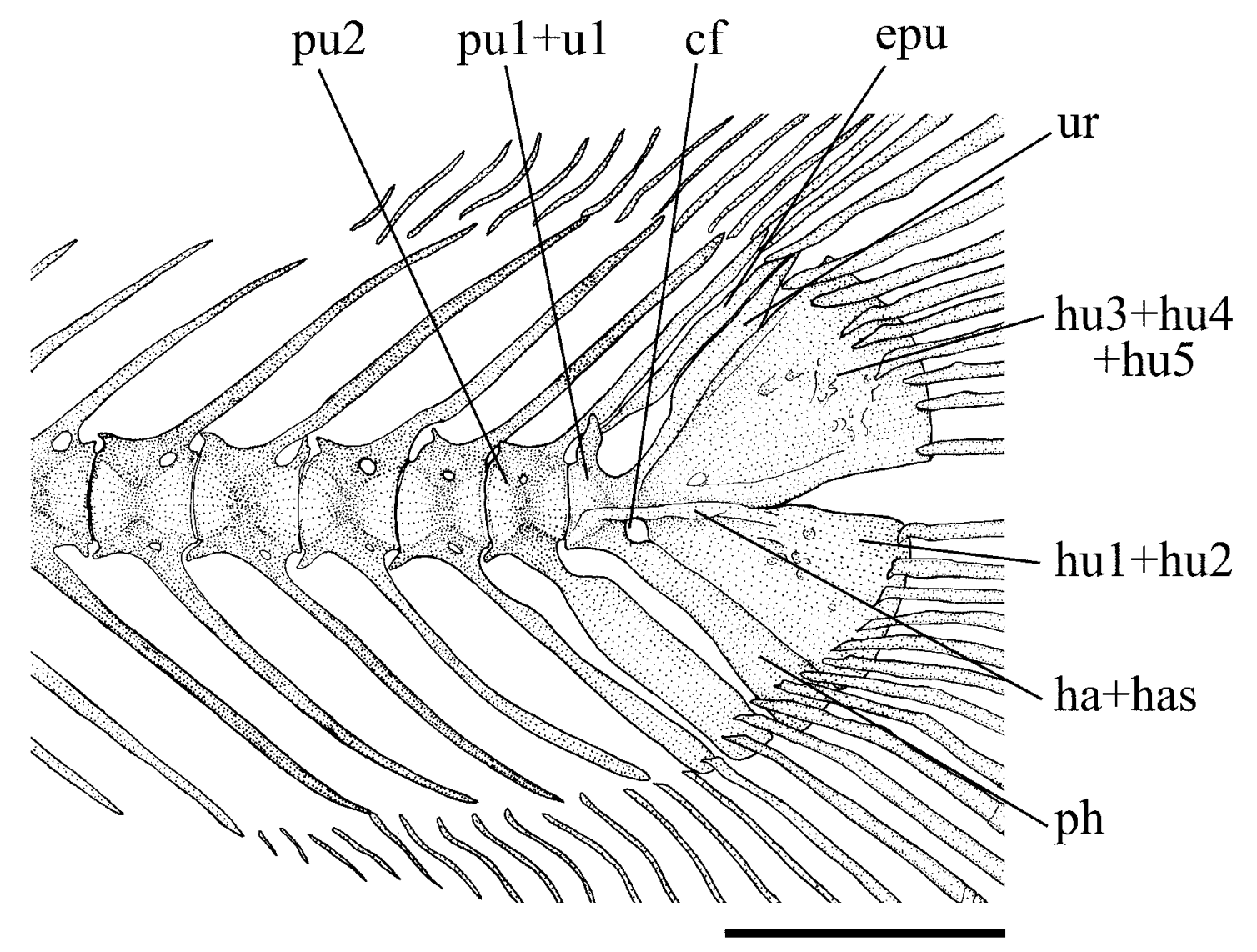

FIGURE 20. Caudal skeleton of Rhamdella cainguae, LIRP 3045, male, 149.9 mm SL, paratype. Lateral view. Opistural cartilage not represented. Scale bar $=5 \mathrm{~mm}$.

The infraorbital laterosensory canal is joined to the supraorbital laterosensory canal via its antorbital branch anteriorly and to the otic and supraorbital laterosensory canals posteriorly (Figs. 3, 4, 7, and 8). The anterior portion of the infraorbital laterosensory canal originates in the anterior region of the snout and runs through all suborbital bones. The posterior portion of the infraorbital laterosensory canal enters the cranium via an opening on the anterolateral border of the sphenotic spine. The infraorbital laterosensory canal has six branches. The il branch is anterolaterally oriented and originates from the anterior opening of suborbital bone 1. The i1 pore is placed posterolateral to the anterior nare and medial to the maxillary-barbel base. The i2 (antorbital) branch is long, medially directed, partially surrounded by the antorbital tubule. The i2 (antorbital) branch is joined to the $\mathrm{s} 2$ branch of the supraorbital laterosensory canal with it which shares a complex pore (the s2+i2 pore; see description of supraorbital laterosensory canal above). The $\mathrm{i} 3$ branch is very short, located immediately above the infraorbital laterosensory canal, laterally directed, and originates from the region of the infraorbital laterosensory canal between suborbital bones 1 and 2 . The i3 pore is situated above the middle of the facial ridge approximately on the line through the anterior margin of the posterior nares. The i4 branch is very short, laterally directed, and originates from the region of the infraorbital laterosensory canal between 
suborbital bones 2 and 3 . The i4 pore is located just posterior to the end of the facial ridge, approximately on the vertical through the anterior margin of the orbits. The i5 branch is posteriorly directed and originates from the region of the infraorbital laterosensory canal between the suborbital bones 3 and 4 . The i5 pore is situated just below the posterior third of the orbit. The i6 branch is short (but longer than i4 and i5 branches), posteroventrally directed, and originates from the infraorbital laterosensory canal between suborbital bone 4 and the opening on the sphenotic spine. The i6 pore is located behind the orbit, approximately on the vertical through the $\mathrm{s} 8$ (parietal) pore and $\mathrm{pm} 9$ pores.

The preoperculomandibular laterosensory canal is long and continuous, mostly running within the dentary and the preopercle (Figs. 3-5, 7, 8, 10, and 11). This canal extends from the region near the mandibular symphysis (but is not connected to its counterpart) to the posterior portion of the cranium where it is united with the po1 branch of the postotic laterosensory canal. The anteriormost portion of the preoperculomandibular laterosensory canal is primarily associated with the lower jaw and is greatly enlarged. Most of the branches of the preoperculomandibular laterosensory canal are very short and almost inconspicuous, such that some pores appear to be situated directly on the main laterosensory canal. The preoperculomandibular laterosensory canal bears 11 branches (pm), with the five anteriormost behind the lower lip. The pm1 branch is medium-sized, offset posteriorly, and originates from the small opening at the mesoventral border of the dentary. The pm1 pore is situated near the mandibular symphysis close to its antimere. The pm2 branch is anteriorly oriented and originates from the large lateroventral opening in the anterior portion of the anterior one third of the dentary. The pm2 pore is situated in front of inner mental barbel, near to the submandibular groove origin. The $\mathrm{pm} 3$ is anteriorly oriented and originates from the large lateroventral opening on the posterior portion of the first third of dentary. The pm3 pore is located slightly posterior to the submandibular groove, approximately on the vertical between the inner and outer mental barbels. The pm4 branch is posteriorly directed and originates from the large mesoventral opening at end of anterior one third of the dentary. The pm4 pore is located posterior to the submandibular groove and in front of the base of the outer mental barbel, equidistant from those structures. The pm5 branch is posteriorly directed and originates from the large ventrolateral opening on the anterior portion of the second one-third of the dentary. The pm5 pore is located behind the submandibular groove and is aligned laterally with the distal extremity of the gape. The pm6 branch is posteriorly directed and originates from the large ventral opening on the posterior portion of the second one-third of the dentary. The pm6 pore is located distinctly behind the vertical through the base of the mental barbels. The pm7 branch is ventrally directed and originates from the large ventral opening on the posterior one-third of the dentary. The pm7 pore is located approximately on the vertical through the apex of the gular fold in ventral view and below the vertical through the i4 pore in lateral view. The $\mathrm{pm} 7$ pore is situated ventral of the level of the main series of pores of the preoperculomandibular canal in lateral view. The pm8 branch is posteriorly directed and originates from the region of the preoperculomandibular laterosensory canal between the posteriormost opening of the dentary and the anteriormost opening of the preopercle. The region of the preoperculomandibular laterosensory canal above the pm 8 branch is dorsomedially surrounded by an incomplete tubular ossicle (the subpreopercle). The pm8 pore is situated immediately behind the vertical through the middle of the orbit. The pm9 branch is long, posteroventrally directed, and originates from the second opening of the preopercle nearly below the cartilaginous block between quadrate and hyomandibula and above the interopercle. The pm9 pore is located almost on the outer border of the opercle, just posterior to the line through s8 (parietal) and 16 pores. The pm10 branch is long, posteroventrally oriented, and originates from the third opening of the preopercle nearly at its midlength. The pm10 pore is located almost on the outer border of opercle, ventral of the level of the i4-5 pores. The pm11 branch originates from the posteriormost opening of the preopercle, is fused to the pol branch of the postotic (or temporal) laterosensory canal, and shares with this laterosensory canal the po1+pm11 complex pore (see description of postotic laterosensory canal above).

The lateral-line canal is continuous, and extends without interruption to the midway of the caudal fin (Figs. 3 and 4). The anterior portion of the lateral line has posteroventrally-directed branches and is sur- 
rounded by small tubular ossicles. The anteriomost portion of the lateral line has longer branches and a higher degree of ossification.

\section{Results and discussion}

Character description and cladistic analysis

To investigate the phylogenetic relationships among species herein recognized in Rhamdella, and of this genus within the family Heptapteridae, a parsimony analysis was performed on a dataset including eleven terminals (one as outgroup) and 23 morphological characters (Table 2). An all-zero outgroup representing a hypothetical ancestor, summarizing the character states of the remaining siluriforms, was used to place the root. The ingroup is composed of the five species of Rhamdella here considered as valid ( $R$. aymarae, $R$. cainguae, $R$. eriarcha, R. longiuscula, and R. rusbyi - see below), the basal heptapterids Brachyrhamdia, Goeldiella, Pimelodella, and Rhamdia (represented by R. quelen, the valid species for the type species of this genus, Pimelodus sebae), and the monophyletic group herein named Clade D which encompasses the Nemuroglanis sub-clade (Ferraris 1988; Bockmann 1994) plus Brachyglanis, Gladioglanis, Leptorhamdia, and Myoglanis. The monophyly of this latter group was first proposed by Lundberg et al. (1991) and later corroborated by de Pinna (1993) and Bockmann (1998). The framework for outgroup comparisons is provided by the hypothesis of relationships of the Heptapteridae proposed by Bockmann (1998). A simplified version of his cladogram appears in Trajano and Bockmann (1999).

TABLE 2. Matrix and list of character states for the family Heptapteridae and genus Rhamdella.

\begin{tabular}{lccc}
\hline Taxon & Character state & & \\
& $1-10$ & 0000000000 & 000 \\
\hline Outgroup & 0000000000 & 1110000000 & 110 \\
Clade D & 0000000100 & $11 ? 1001000$ & $00 ?$ \\
Brachyrhamdia & 0000000000 & 0010001000 & 000 \\
Goeldiella & 0002000000 & 1101001000 & $00 ?$ \\
Pimelodella & 0000000000 & $1100 ? 01000$ & 010 \\
Rhamdia & 0000000100 & 1101100000 & 011 \\
Rhamdella aymarae & 0002001101 & 1110011111 & 101 \\
Rhamdella cainguae & 1112112110 & 1110011110 & 101 \\
Rhamdella eriarcha & 1112102110 & 1110011111 & 101 \\
Rhamdella longiuscula & 1112102110 & 1111100000 & 010 \\
Rhamdella rusbyi & 0001001101 & & \\
\hline
\end{tabular}

The following characters were analyzed in the present study:

1. Shape of anterolateral cornu of the mesethmoid ( $s=1, c i=1.00, r i=1.00)$. State 0 (long and tapered): outgroup, Brachyrhamdia, Clade D, Goeldiella, Pimelodella sp., R. aymarae, R. rusbyi, and Rhamdia. State 1 (short and blunt-tipped): R. eriarcha, $R$. longiuscula, and $R$. cainguae. Primitively in siluriforms, the anterolateral cornu of the mesethmoid is relatively long and tapered, with its tip, in dorsal view, reaching or surpassing the same parasagital plane through the lateral tip of the posterolateral cornu of the mesethmoid. This condition is present in most heptapterids examined, such as Pimelodella sp. (Fig. 21). In R. eriarcha, $R$. longiuscula, and $R$. cainguae, in contrast, the anterolateral cornu of the mesethmoid is comparatively short, with its tip not reaching the level of the lateral tip of the posterolateral cornu of the mesethmoid (Fig. 7). 


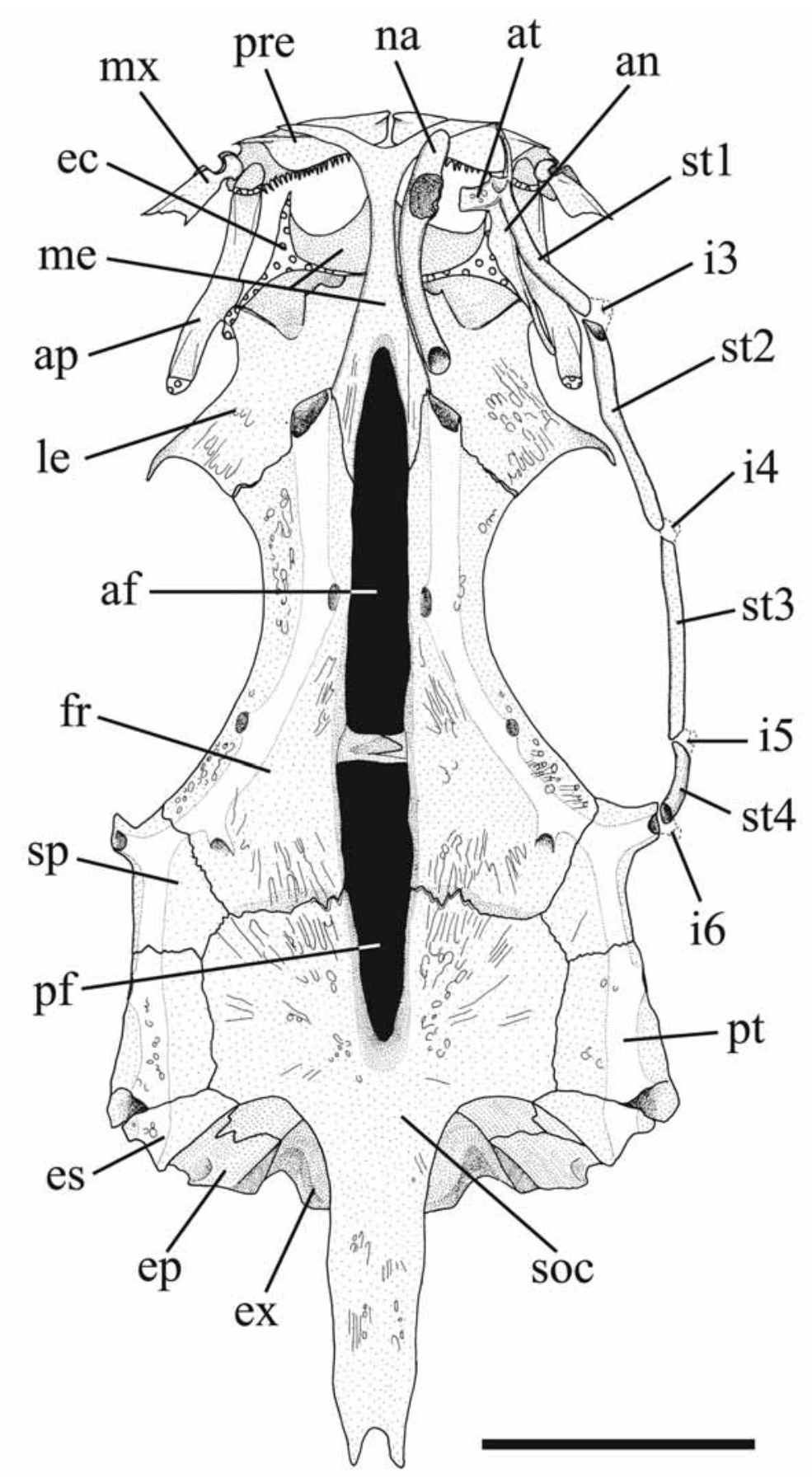

FIGURE 21. Cranium of Pimelodella sp., UFRJ 502, $62.4 \mathrm{~mm}$ SL. Dorsal view. Scale bar = $4 \mathrm{~mm}$.

2. Shape of premaxilla $(s=1, c i=1.00, r i=1.00)$. State 0 (rectangular and considerably wider than long): outgroup, Brachyrhamdia, Clade D, Goeldiella, Pimelodella, $R$. aymarae, R. rusbyi, and Rhamdia. State 1 (long and narrow): $R$. eriarcha, $R$. longiuscula, and $R$. cainguae. Primitively in catfishes, the premaxilla is rectangular and considerably wider than long (in relation to the main axis of the fish), so that its length at the midpoint of its longest axis is approximately $30 \%$ of its width. In contrast, the length of the premaxilla in $R$. eriarcha, $R$. longiuscula, and $R$. cainguae is nearly $45 \%$ of its width (Fig. 8 ). Within Clade D, a further modification of this state is homoplastically present in Leptorhamdia species.

3. Posterolateral angle of the premaxilla $(s=1, c i=1.00, r i=1.00)$. State 0 (without conspicuous posteriorly-directed projection): outgroup, Brachyrhamdia, Clade D, Goeldiella, Pimelodella, R. aymarae, R. rusbyi, 
and Rhamdia. State 1 (with conspicuous posteriorly-directed projection): $R$. eriarcha, $R$. longiuscula, and $R$. cainguae. Plesiomorphically in heptapterids, the posterolateral angle of the premaxilla lacks a projection. In Rhamdella species listed above, the posterolateral angles of the premaxillae have noticeable posteriorlydirected projections, which are devoid of teeth at their tips only (Fig. 8). Within Clade D, this state occurs homoplastically in species of Chasmocranus (see figs. 1B-C of Mees 1967) and Phenacorhamdia, and is particularly conspicuous in Phreatobius cisternarum.

4. Size of openings in the frontal for exit of s6 (epiphyseal) branch of supraorbital laterosensory canal ( $s=5, c i=0.40, r i=0.62$ ). State 0 (as large as the openings leading for other supraorbital sensory branches): outgroup, Brachyrhamdia, Clade D, Pimelodella, and Rhamdia. State 1 (larger than openings for other supraorbital sensory branches): $R$. rusbyi. State 2 (much larger than openings for other supraorbital sensory branches): Goeldiella, $R$. aymarae, $R$. eriarcha, $R$. longiuscula, and $R$. cainguae. In most members of the family Heptapteridae, this orifice is only as large as those leading for other supraorbital sensory branches; the condition exhibited by Pimelodella sp. (Fig. 21). In Goeldiella and all species of Rhamdella recognized (Fig. 7), in contrast, the foramen in the frontal for exit of s6 (epiphyseal) branch is considerably larger than the foramina for other laterosensory canal system branches on the head, as illustrated for $R$. aymarae by Miquelarena and Menni (1999: 207, fig. 7). The openings in the frontal for exit of s6 branch of Goeldiella, $R$. aymarae, $R$. cainguae (Fig. 7), R. eriarcha, and $R$. longiuscula are somewhat larger than that of $R$. rusbyi. Thus, the more markedly expanded openings are recognized as a derived feature, coded as State 2 . These derived conditions occur, presumably homoplastically, in Brachyglanis, Gladioglanis, Leptorhamdia, and Myoglanis (see figures in Ferraris and Mago-Leccia 1986; Lundberg et al. 1991).

5. Position of opening for s6 branch of supraorbital laterosensory canal in the frontal $(s=1, c i=1.00$, $r i=1.00$ ). State 0 (medial): outgroup, Brachyrhamdia, Clade D, Goeldiella, Pimelodella, R. aymarae, R. rusbyi, and Rhamdia. State 1 (dorsal): $R$. cainguae, $R$. eriarcha, and $R$. longiuscula. The widespread position of the exit in the frontal bone for the epiphyseal branch of the supraorbital laterosensory canal among heptapterids is that present in species of Pimelodella (Fig. 21), where it exits medially. In Rhamdella species listed above as having State 1, the opening for exit of s6 branch is instead situated dorsally in the frontal (Fig. 7). This derived state occurs homoplastically in members of Brachyglanis, Gladioglanis, Leptorhamdia, and Myoglanis.

6. A large, differentiated ovoid area on the supraorbital laterosensory canal located at the frontal-sphenotic boundary ( $s=1, c i=1.00, r i=1.00)$. State 0 (absent): outgroup, Brachyrhamdia, Clade D, Goeldiella, Pimelodella, $R$. aymarae, $R$. eriarcha, $R$. longiuscula, $R$. rusbyi, and Rhamdia. State 1 (present): $R$. cainguae. Rhamdella cainguae uniquely has a differentiated area at the frontal-sphenotic boundary on the supraorbital laterosensory canal (Fig. 7, see arrow), a feature unique to this species among examined heptapterids. The dorsal walls of the bones in that area are thinner, delimiting an ovoid area, but no foramen is present.

7. Size of optic foramen ( $s=2, c i=1.00, r i=1.00$ ). State 0 (as large as the foramen for trigeminofacial nerve): outgroup, Brachyrhamdia, Clade D, Goeldiella, Pimelodella, and Rhamdia. State 1 (larger than foramen for trigeminofacial nerve): $R$. aymarae and $R$. rusbyi. State 2 (much larger than foramen for trigeminofacial nerve): $R$. cainguae, $R$. eriarcha, and $R$. longiuscula. Primitively in siluriforms, the optic foramen is approximately as large as the foramen for the trigeminofacial nerve (Bockmann 1998). The plesiomorphic condition was illustrated for Brachyrhamdia imitator (Lundberg and McDade 1986). In all Rhamdella species other than R. aymarae and R. rusbyi, the optic foramen is noticeably larger than the trigeminofacial (State 2; Figs. 8 and 22). In $R$. aymarae and $R$. rusbyi the optic foramen albeit larger than in most heptapterids, is never as elongate as that in $R$. cainguae, $R$. eriarcha, and $R$. longiuscula (State 1). 


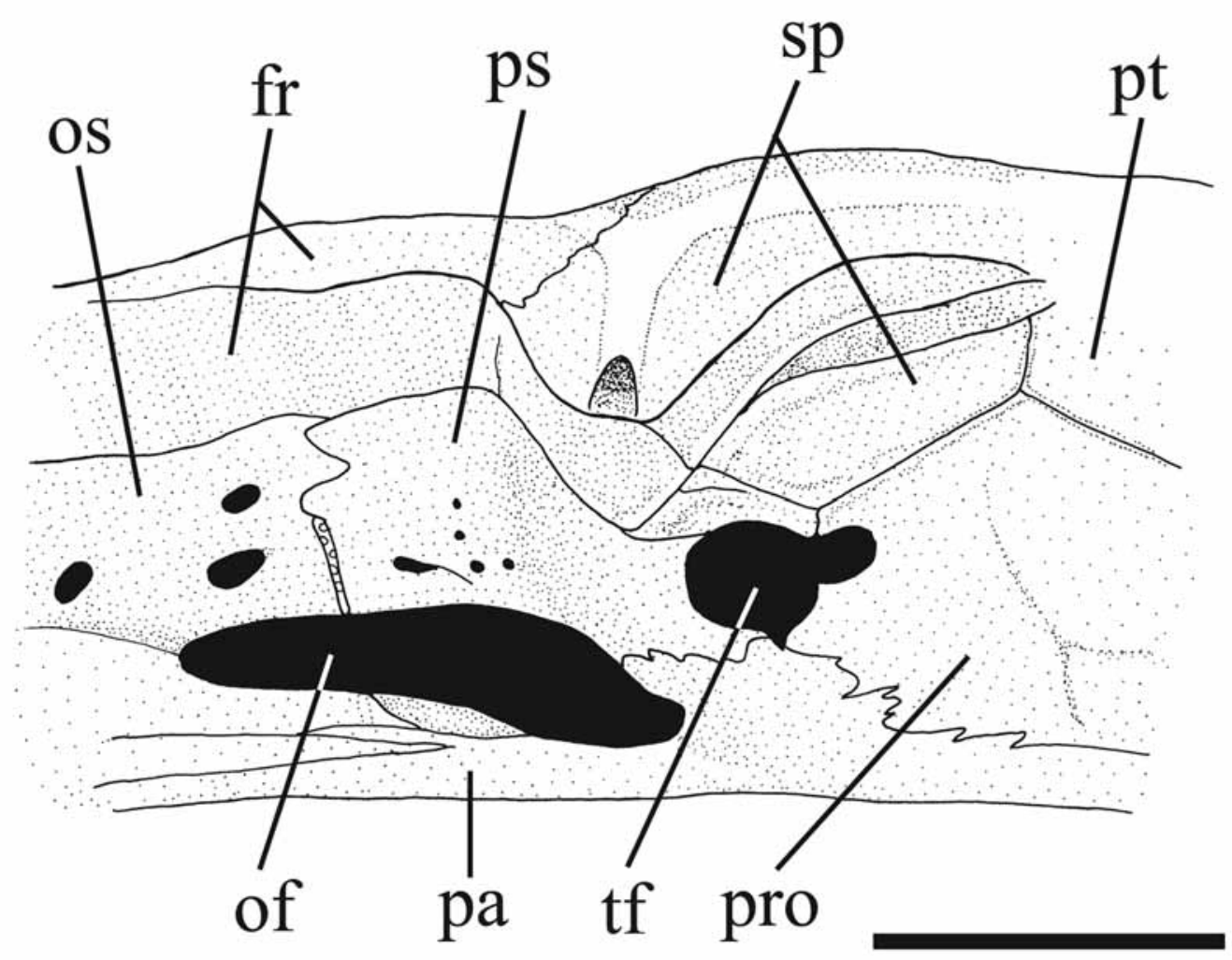

FIGURE 22. Left medial portion of the cranium of Rhamdella longiuscula, MCP 12722, 123.0 mm SL, paratype. Lateral view. Scale bar $=3 \mathrm{~mm}$.

8. Length of supraoccipital process $(s=1, c i=1.00$, ri=1.00). State 0 (long, reaching nuchal plate): outgroup, Brachyrhamdia, Goeldiella, and Pimelodella. State 1 (short, not reaching nuchal plate): Clade D, $R$. aymarae, $R$. cainguae, $R$. eriarcha, $R$. longiuscula, $R$. rusbyi, and Rhamdia. Primitively, the supraoccipital posterior process is very long, contacts the supraneural, and often notched posteriorly. In the Heptapteridae, this is the case in Brachyrhamdia (cf. Lundberg and McDade 1986: 6, fig. 3; 11, fig. 6), Goeldiella, and Pimelodella (Fig. 21). Alternatively, in Rhamdella (Figs. 7 and 8) and in all remaining heptapterids, the supraoccipital process is shorter than in the primitive condition, and never reaches the nuchal plate. The state of that process in species of Rhamdella is similar to that of Rhamdia quelen, with its distal portion embedded in muscular nape tissue such that its length can only be accurately determined with dissection. The state of development of the supraoccipital process of those taxa seems to be the first step in a complex transformation series of a progressive reduction of that structure, such as occurs in some derived heptapterids. Further discrimination of different states for this feature is not pertinent to the present discussion.

9. Width of anteriormost portion of the preoperculomandibular laterosensory canal, mainly in lower jaw $(s=1, c i=1.00, r i=1.00)$. State 0 (narrow): outgroup, Brachyrhamdia, Clade D, Goeldiella, Pimelodella, $R$. aymarae, $R$. rusbyi, and Rhamdia. State 1 (enlarged): $R$. cainguae, $R$. eriarcha, and $R$. longiuscula. The anterior portion of the preoperculomandibular laterosensory canal of $R$. eriarcha, $R$. longiuscula, and $R$. cainguae, is greatly enlarged, a modification reflected in the large openings for the exit of the sensory branches in dentary and the wide subpreopercle (Figs. 10 and 11). In the plesiomorphic condition, the anterior portion of preoperculomandibular laterosensory canal is narrow and of approximately equal width along its entire length.

10. Suprapreopercle $(s=1, c i=1.00, r i=1.00)$. State 0 (absent or weakly developed, not forming a conspicuous tubule): outgroup, Brachyrhamdia, Clade D, Goeldiella, Pimelodella, $R$. cainguae, $R$. eriarcha, $R$. longiuscula, and Rhamdia. State 1 (present and well developed, forming a conspicuous tubule): $R$. aymarae and $R$. rusbyi. Plesiomorphically, the portion of the preoperculomandibular laterosensory canal situated 
between the posteriormost extremity of the preopercle (at level of the hyomandibular condyle for the opercle) and the point of origin of the po1+pm11 branch is unossified or bears a discrete superficial ossification. In $R$. aymarae and $R$. rusbyi that portion of the preoperculomandibular laterosensory canal is distinctly ossified and well delimited, forming a separate tubule, which is usually called suprapreopercle. This element was described and illustrated for R. aymarae by Miquelarena and Menni (1999: 207, fig. 8B).

11. Shape of hypobranchial 1 ( $s=1, c i=1.00, r i=1.00)$. State 0 (quadrangular): outgroup and Goeldiella. State 1 (rectangular): Brachyrhamdia, Clade D, Pimelodella, $R$. aymarae, $R$. cainguae, $R$. eriarcha, $R$. longiuscula, $R$. rusbyi, and Rhamdia. In most siluriforms and other otophysans, hypobranchial 1 is quadrangular (i.e. approximately as long as long), and plesiomorphically retains a well-developed layer of cartilage along its posterior margin (de Pinna, 1993: 198, his character 147; Bockmann, 1998: 232-233, his character 100). The basal siluriform families Diplomystidae and Cetopsidae (de Pinna 1998) exhibit the plesiomorphic state (cf. Arratia 1987: 42, figs. 17A-B; 56, fig. 27B; Azpelicueta 1994: 230, figs. 6A-B; 234, fig. 11; de Pinna and Vari 1995: 7, fig. 5). In heptapterids, this state occurs only in Goeldiella (Fig. 23). In all remaining heptapterids, hypobranchial 1 is rectangular (i.e. distinctly wider than longer), and sometimes cartilage is lacking posteriorly, being restricted to the tips of the bone (Figs. 13, 14, and 24). The derived state was illustrated for the heptapterids Brachyrhamdia imitator (Lundberg and McDade 1986: 15, fig. 10D) and Rhamdia quelen (Silfvergrip 1996: 110, fig. 32).

12. Anterolateral projection of hypobranchial $3(s=1, c i=1.00$, ri=1.00). State 0 (absent): outgroup and Goeldiella. State 1 (present): Brachyrhamdia, Clade D, Pimelodella, $R$. aymarae, $R$. cainguae, $R$. eriarcha, $R$. longiuscula, $R$. rusbyi, and Rhamdia. Primitively in siluriforms, hypobranchial 3 is roughly quadrangular, without any conspicuous projection. This plesiomorphic condition is present in the basal siluriforms Diplomystidae and Cetopsidae (cf. Azpelicueta 1994: 230, figs. 6A-B; de Pinna and Vari 1995: 7, fig. 5). The only Heptapteridae with that state is Goeldiella (Bockmann 1998: 234, his character 105; Fig. 23). The hypobranchial 3 of all remaining heptapterids is somewhat laterally elongate, with a distinct anterolateral projection at its anterolateral apex (Figs. 14 and 24). This condition, considered to be apomorphic, was illustrated for the heptapterids Brachyrhamdia imitator (Lundberg and McDade 1986: 15, fig. 10D) and Rhamdia quelen (Silfvergrip 1996: 110, fig. 32).

13. Pharyngobranchial 1 ( $s=3, c i=0.33, r i=0.33)$. State 0 (present): outgroup, $R$. aymarae, Pimelodella, and Rhamdia. State 1 (absent): Clade D, Goeldiella, $R$. cainguae, $R$. eriarcha, $R$. longiuscula, and $R$. rusbyi. State? (undetermined): Brachyrhamdia. The pharyngobranchial 1 in siluriforms is a cylindrical rod which is usually ossified for most of its length, lying parallel to epibranchial 1, and is ligamentously attached to the inner surface of hyomandibula. Arratia (1992, her character 33) coded the presence of this element as apomorphic in siluriforms, since she considered it to be non-homologous to the pharyngobranchial 1 of other teleosteans. The coding of this feature for Brachyrhamdia is puzzling, since pharyngobranchial 1 is either present $(B$. marthae and $B$. meesi) or absent (B. imitator) in the genus. This structure is plesiomorphically present in basal members of the Heptapteridae, such as Pimelodella spp. (Fig. 24), Rhamdia laticauda, and R. quelen (Silfvergrip 1996: 110, fig. 32). On the other hand, this structure is apomorphically absent in Goeldiella, all Rhamdella species (Fig. 14) except $R$. aymarae, and all remaining heptapterids (e.g. Brachyglanis, Cetopsorhamdia, Gladioglanis, Heptapterus, Imparfinis, Leptorhamdia, and Mastiglanis).

14. Number of branchiostegal rays ( $s=2, c i=0.50, r i=0.66)$. State 0 (seven or more): outgroup, Clade D, Goeldiella, R. cainguae, R. eriarcha, R. longiuscula, and Rhamdia. State 1 (six): Brachyrhamdia, Pimelodella, $R$. aymarae, and $R$. rusbyi. The most basal siluriform family, Diplomystidae, has eight to 10 branchiostegal rays (Arratia 1987). The widespread number of branchiostegal rays among heptapterids is seven or more, with Brachyrhamdia, Pimelodella, R. aymarae, and R. rusbyi having six (Miquelarena and Menni 1999; pers. obs.). Within Heptapteridae, the derived state is homoplastically present in Gladioglanis, Leptorhamdia, Pimelodella, and Rhamdia laticauda. 


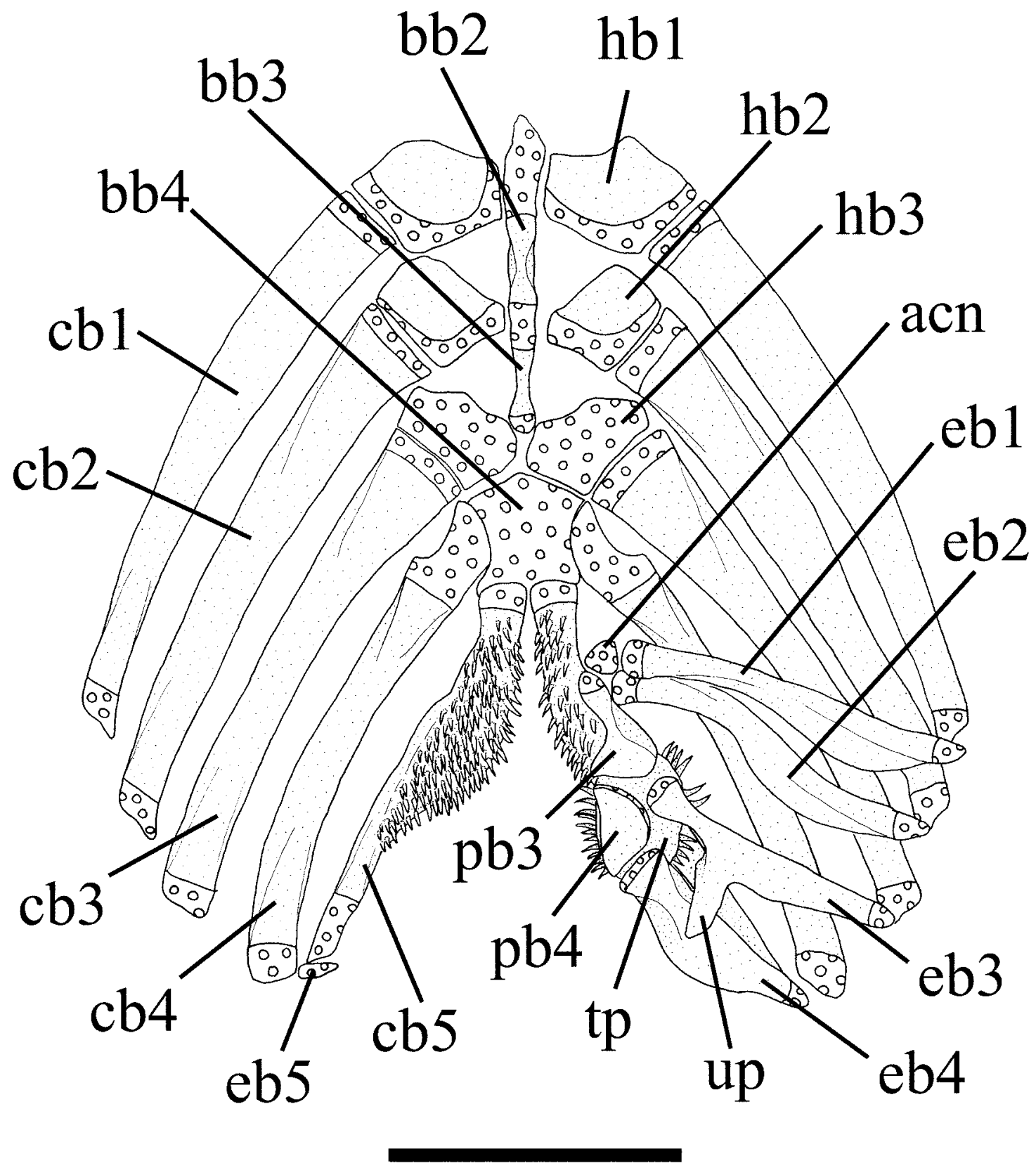

FIGURE 23. Gill arches of Goeldiella eques, MZUSP 45907, 78.5 mm SL. Dorsal view. Gill rakers and dorsal elements of left gill arches not shown. Scale bar $=5 \mathrm{~mm}$.

15. Number of total vertebrae ( $s=1, c i=1.00, r i=1.00)$. State 0 (37-45 vertebrae): outgroup, Brachyrhamdia, Clade D, Goeldiella, Pimelodella, $R$. cainguae, $R$. eriarcha, and $R$. longiuscula. State 1 (47 vertebrae): $R$. aymarae and $R$. rusbyi. State? (undetermined): Rhamdia. There is a great range of variation of total vertebrae in the Heptapteridae, with each class of variation being consistent and therefore informative for various groups (Bockmann 1998). Most of the members of the Heptapteridae (e.g. Cetopsorhamdia, Chasmocranus, Goeldiella, Imparfinis, Mastiglanis, Nemuroglanis, Phenacorhamdia, Pimelodella, Rhamdiopsis), and some of them distantly related to Rhamdella, have 37-45 total vertebrae (Bockmann, 1998). The number of total vertebrae of all examined specimens of Rhamdella other than R. aymarae and R. rusbyi falls within those limits. Specimens of $R$. cainguae have 43 (2) or 44 (1) vertebrae. The two C \& S examined specimens of $R$. eriarcha have 44 vertebrae (pers. obs.; Silva, pers. obs.). Lucena and Silva (1991) reported 37 and 40 vertebrae (43 
and 46, respectively, according the methodology for counting vertebrae which included all elements, as done in this study) for $R$. longiuscula. Our examination of those specimens revealed 43 and 45 vertebrae. Rhamdella aymarae and $R$. rusbyi has a derived count for total vertebrae, as all $\mathrm{C} \& \mathrm{~S}$ specimens (three of $R$. aymarae and one of $R$. rusbyi) with 47 vertebrae. The state of this character for Rhamdia was coded as undetermined because this taxon has both 45 and 47 vertebrae (Bockmann 1998).

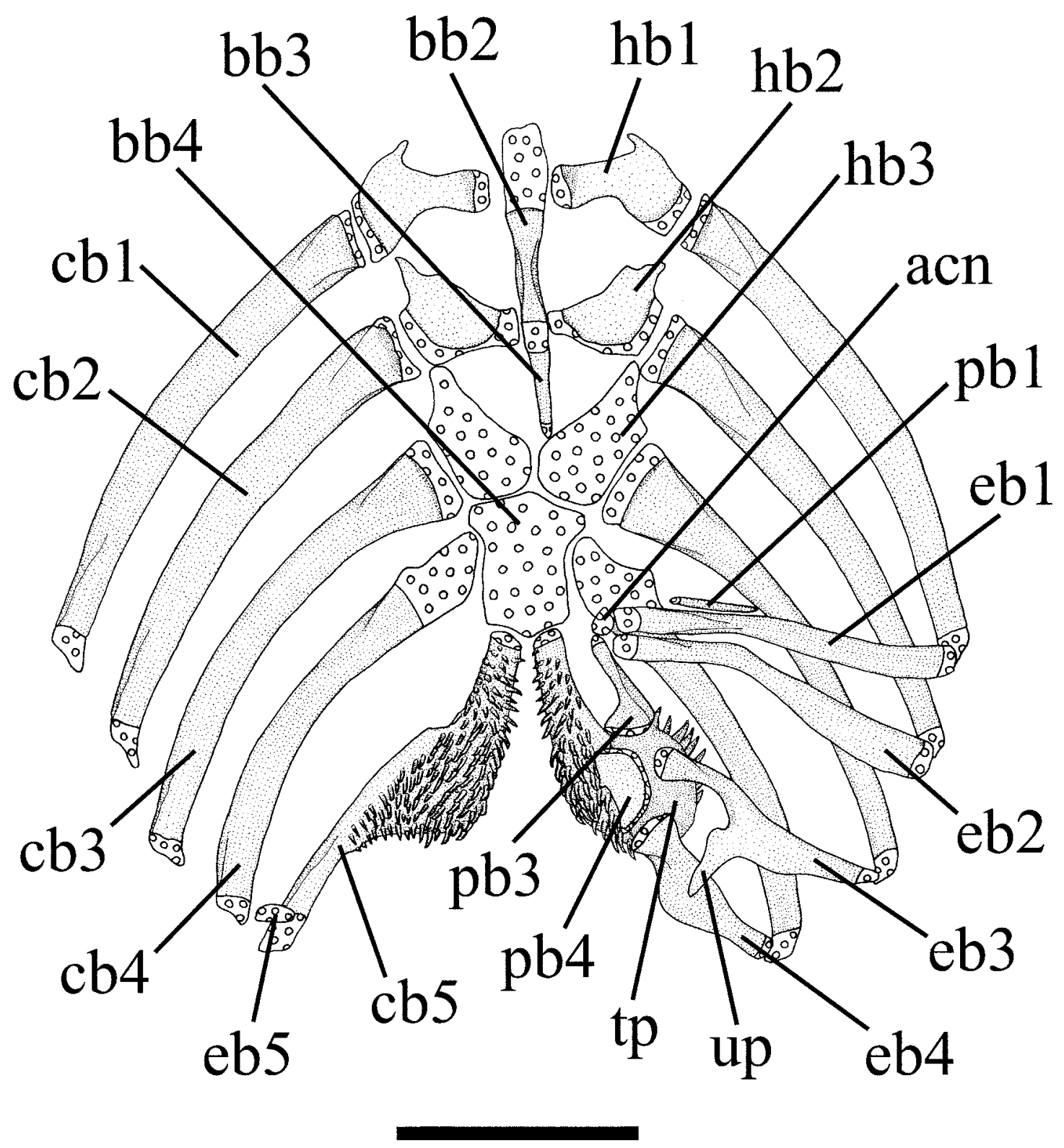

FIGURE 24. Gill arches of Pimelodella sp., UFRJ 503, $89.5 \mathrm{~mm}$ SL. Dorsal view. Gill rakers and dorsal elements of left gill arches not shown. Scale bar $=3 \mathrm{~mm}$.

16. Junction between the anterior and posterior branches of transverse process $4(s=1, c i=1.00, r i=1.00)$. State 0 (absent): outgroup, Brachyrhamdia, Clade D, Goeldiella, Pimelodella, $R$. aymarae, $R$. rusbyi, and Rhamdia. State 1 (present): R. cainguae, R. eriarcha, and R. longiuscula. In R. cainguae, R. eriarcha, and $R$. longiuscula, the posterior border of the anterior branch and the anterior margin of the arborescent portion of the posterior branch of the transverse process of vertebra 4 are joined to each other via a bony bridge that delimits a large, rounded foramen between them (Fig. 15, see arrow). In the plesiomorphic state the anterior and posterior branches of transverse process 4 do not join each other (Fig. 25). 


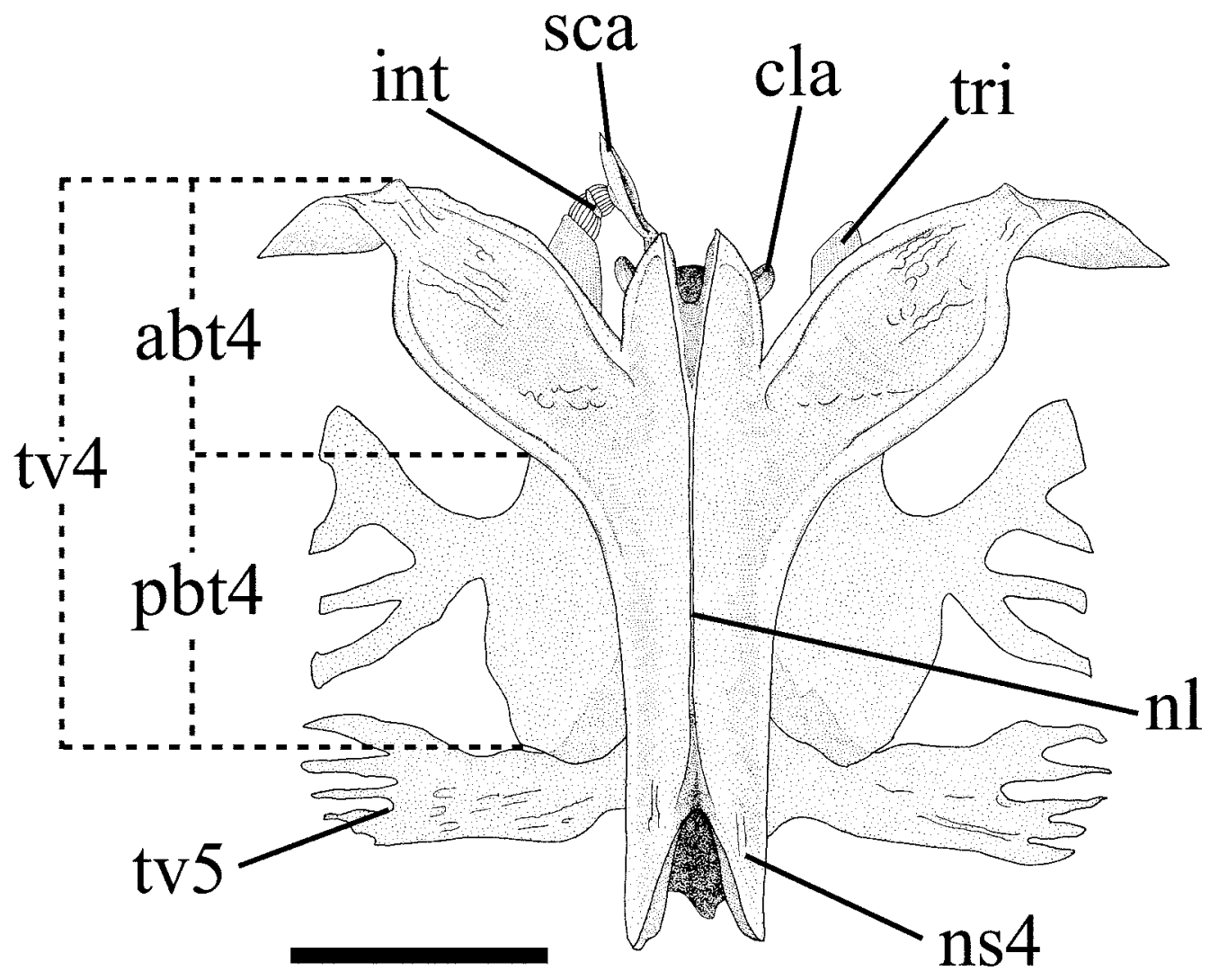

FIGURE 25. Anterior vertebrae of Pimelodella sp., UFRJ 502, $62.4 \mathrm{~mm} \mathrm{SL}$. Dorsal view. Scale bar $=2 \mathrm{~mm}$.

17. Morphology of the tip of transverse process of the vertebra $5(s=3, c i=0.33$, ri $i=0.33)$. State 0 (simple, not branched): outgroup, Clade D, R. aymarae, and R. rusbyi. State 1 (expanded and branched): Brachyrhamdia, Goeldiella, Pimelodella, $R$. cainguae, $R$. eriarcha, $R$. longiuscula, and Rhamdia. The distal extremity of the transverse process of vertebra 5 of the most members of the genera Brachyrhamdia, Goeldiella, Pimelodella, and Rhamdia, basal clades of the family Heptapteridae, are apomorphically expanded and branched (cf. Bockmann 1994; Chardon 1968; Lundberg and McDade 1986; Fig. 25), as first described by Lundberg and McDade (1986). Within Rhamdella, an expanded and branched tip of the transverse process of vertebra 5 is present in $R$. cainguae, $R$. eriarcha, and $R$. longiuscula (Fig. 15). On the other hand, the tip of transverse process of vertebra 5 of $R$. aymarae and $R$. rusbyi is simple, not expanded or branched. Miquelarena and Menni (1999) considered this feature as an autapomorphy for $R$. aymarae. The tip of the left transverse process of vertebra 5 of the $\mathrm{C} \& \mathrm{~S}$ specimen of the $R$. rusbyi has a small posterior process which gives it a somewhat branched aspect. Except for this detail, the tips of the transverse processes of the vertebra 5 of that specimen are not different from those seen in R. aymarae. This state is considered plesiomorphic within the siluriforms. All members of the Clade D also exhibit this plesiomorphic condition, as illustrated for Gladioglanis conquistador (Lundberg et al. 1991: 196, fig. 6A), Gladioglanis machadoi (Ferraris and Mago-Leccia 1989: 170, fig. 5; Lundberg et al. 1991: 196, fig. 6B), Heptapterus sympterygium (Buckup 1988: 646, fig. 4), Imparfinis minutus (Bockmann 1994: 773, fig. 8B), Mastiglanis asopos (Bockmann 1994: 773, fig. 8A), Nannorhamdia sp. (Lundberg and McDade 1986: 7, fig. 4C), and Nemuroglanis pauciradiatus (Ferraris 1988: 514, fig. 3).

18. Number of anal-fin rays $(s=1, c i=1.00, r i=1.00)$. State 0 (13-15 rays, more rarely 12 and 16): outgroup, Brachyrhamdia, Clade D, Goeldiella, Pimelodella, R. aymarae, R. rusbyi, and Rhamdia. State 1 (1618, commonly 17): $R$. cainguae, $R$. eriarcha, and $R$. longiuscula. A relatively short anal with $13-15$ rays (more rarely 12 and 16) supported by 10-12 basal radials, appears to be the plesiomorphic state in siluriforms. 
This primitive condition is exhibited by numerous heptapterid species of several genera, such as Brachyglanis, Brachyrhamdia, Cetopsorhamdia, Chasmocranus, Goeldiella, Horiomyzon, Imparfinis, Leptorhamdia, Mastiglanis, Nemuroglanis , Pariolius, Phenacorhamdia, Pimelodella, Rhamdia, Rhamdioglanis, and Taunayia. Rhamdella aymarae is also reported to have the primitive count, i.e. 15-16 anal-fin rays (Miquelarena and Menni 1999) as does $R$. rusbyi, with 12-15 anal-fin rays. In contrast, the anal-fin bases of $R$. eriarcha, $R$. longiuscula, and $R$. cainguae are comparatively longer, with 16-18 rays, most commonly 17 , that are supported by $14-15$ basal radials. Very long anal-fin bases, sometimes with more than 20 rays, occur among members of the Clade D, such as Acentronichthys, Gladioglanis, Heptapterus, Myoglanis, Phreatobius, and Rhamdiopsis. However, all these genera are relatively more derived with respect to Rhamdella (Fig. 26), with some (Acentronichthys, Heptapterus, Phreatobius, and Rhamdiopsis) being members of the Nemuroglanis sub-clade (Ferraris 1988; Bockmann 1994). Therefore, the occurrence of a long anal-fin base in those taxa is interpreted as being homoplastic with respect to the occurrence of that feature in $R$. eriarcha, $R$. longiuscula, and $R$. cainguae. Similarly among basal heptapterids, the presence of 17 anal-fin rays in Rhamdia laticauda is also interpreted as convergent (Fig. 26).

19. Association between hypurals 3, 4, and $5(s=1, c i=1.00, r i=1.00)$. State 0 (hypural 5 as an autogenous element): outgroup, Brachyrhamdia, Clade D, Goeldiella, Pimelodella, R. aymarae, R. rusbyi, and Rhamdia. State 1 (completely co-ossified to each other): $R$. cainguae, $R$. eriarcha, and $R$. longiuscula. The dorsal caudal plates of most members of the family Heptapteridae include two isolated hypural elements: the dorsalmost consisting of hypural 5, and the ventralmost, a complex structure formed by the co-ossified hypurals 3 and 4 . This description corresponds to that provided by Lundberg and Baskin (1969) for the majority of species presently assigned to the Heptapteridae, including $R$. aymarae and $R$. rusbyi. The retention of an autogenous hypural 5 is considered the plesiomorphic state, since it is present in the basal families Diplomystidae and Cetopsidae (cf. Lundberg and Baskin 1969). This condition is also exhibited by most examined members of the Heptapteridae. The primitive state for this character is also found in $R$. aymarae, in which hypurals 3, 4 and 5 are completely separated in specimens of $86.2-114.3 \mathrm{~mm} \mathrm{SL}$. In a larger specimen (168.0 mm SL), hypurals 3 and 4 are fused to each other but distinctly separated from hypural 5 . Therefore, the condition in $R$. eriarcha, $R$. cainguae, and $R$. longiuscula, in which the three dorsal hypurals are completely fused (Figs. 19 and 20), is treated as synapomorphic. This state occurs homoplastically within the Clade D, in members of Gladioglanis, Nemuroglanis, and Phreatobius (Fig. 26).

20. Length of dorsal caudal-fin lobe ( $s=1, c i=1.00, r i=1.00$ ). State 0 (with the same length or slightly longer than the ventral lobe): outgroup, Brachyrhamdia, Clade D, Goeldiella, Pimelodella, R. aymarae, $R$. eriarcha, $R$. rusbyi, and Rhamdia. State 1 (much longer than the ventral lobe): $R$. cainguae and $R$. longiuscula. Primitively in catfishes, the caudal-fin lobes are of approximately the same length or the dorsal lobe is slightly longer than the ventral one, a condition exhibited by species of several heptapterid genera (e.g. Goeldiella, Imparfinis, Pimelodella, Rhamdia etc.). In contrast, the dorsal caudal-fin lobe in $R$. longiuscula and $R$. cainguae, especially in males, is considerably longer than ventral lobe (Figs. 1, 2, and 19). The lengths of the ventral caudal-fin lobes of $R$. cainguae (9 male paratypes, $121.0-157.5 \mathrm{~mm} \mathrm{SL}$ ) are $55.8-65.5 \%$ of the lengths of the dorsal lobes. In $R$. longiuscula these proportions are similar, having 55.0\% in one $106.2 \mathrm{~mm}$ SL male. The long dorsal caudal-fin lobe of $R$. longiuscula was employed to distinguish that species from $R$. eriacha (Lucena and Silva 1991). In $R$. aymarae the dorsal caudal-fin lobe is slightly longer than the ventral lobe (holotype and 5 paratypes, all males, $86.7-128.8 \mathrm{~mm} \mathrm{SL}$ ), with the ventral caudal-fin lobe $81.4-94.3 \%$ of the dorsal lobe. In R. rusbyi the proportions of the ventral caudal-fin lobe versus the dorsal caudal-fin lobe in one male paratype ( $164.4 \mathrm{~mm} \mathrm{SL}$ ) is $85.2 \%$ and in two paratypes of undetermined sex $(160.4-168.1 \mathrm{~mm} \mathrm{SL})$ is 84.8-93.7\%. In R. eriarcha this proportion in seven males (127.0-184.0 mm SL) is $75.0-94.7 \%$. A very long dorsal caudal-fin lobe, similar to that of $R$. cainguae and $R$. longiuscula, is present in Acentronichthys leptos, “Imparales" panamensis, Imparfinis borodini, Imparfinis guttatus, Imparfinis hollandi, Imparfinis longicaudus, Imparfinis schubarti, Imparfinis nemacheir, Nannorhamdia stictonotus, and Nemuroglanis lanceolatus. 
However, all these taxa pertain to the Nemuroglanis sub-clade (Clade E; Fig. 26); those conditions are therefore interpreted as homoplastic in relation to that of $R$. cainguae and $R$. longiuscula.

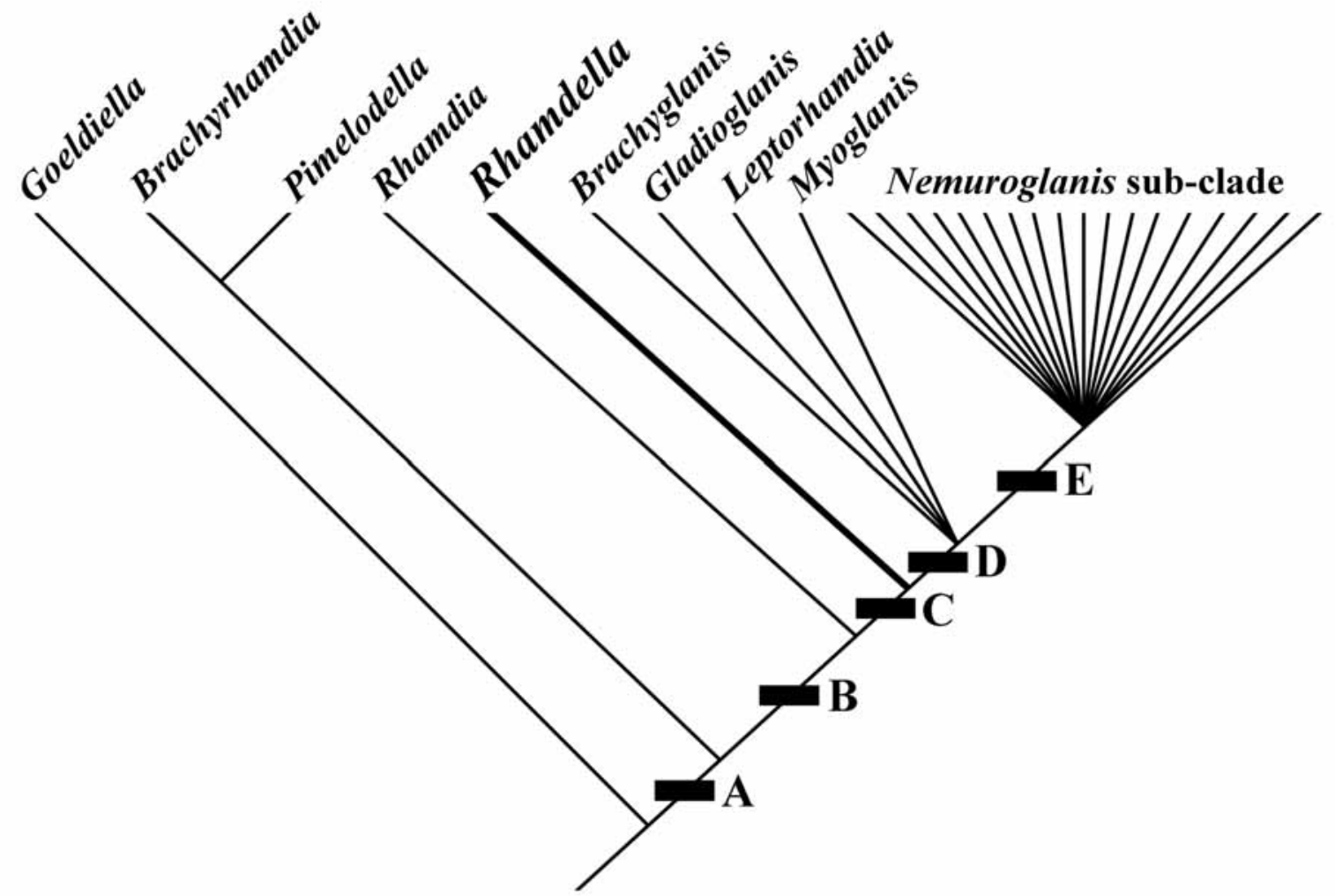

FIGURE 26. Simplified cladogram of the family Heptapteridae. Clades: Family Heptapteridae [synapomorphies: posterior limb of transverse process of vertebra 4 laterally expanded above swim bladder and notched once to several times; neural spines of Weberian complex centrum joined by a straight-edged, horizontal or sometimes sloping bony lamina; tip of transverse process of vertebra 5 expanded and branched; process for insertion of levator operculi muscle on posterodorsal corner of hyomandibula greatly expanded; quadrate with a free dorsal margin and bifid shape, its posterior and anterior limbs articulate separately with hyomandibula and metapterygoid; and ventrolateral corner of mesethmoid with an anteriorly recurved process]; A- unnamed group [synapomorphies: hypobranchial 1 rectangular (character 11, state 1); and hypobranchial 3 with anterolateral projection (character 12, state 1)]; B- unnamed group [synapomorphies: supraoccipital process short, not reaching nuchal plate (character 8, state 1); and eye small, $16.0 \%$ HL or lesser (character 22, state 1)]; C- unnamed group [synapomorphies: pharyngobranchial 1 absent (character 13, state 1); tip of transverse process of vertebra 5 simple, not branched (character 17, state 0)]; D- unnamed group [synapomorphy: free orbital rim reduced or absent]; E- Nemuroglanis sub-clade [synapomorphies: laminar portion of complex centrum transverse process posterior to the branched segment triangular and extending nearly to the lateral tip of the vertebral transverse process 5; first dorsal-fin basal pterygiophore inserted behind the Weberian complex, usually above vertebrae 7 to 10 ; pectoral girdle delicate, with a short mesial contact line comprising only three weakly joined scapulo-coracoid dentations; pointed process projected posteroventrally from the coracoid keel absent; for other features see Ferraris (1988) and Bockmann (1994)].

21. Length of maxillary barbel $(s=1, c i=1.00$, ri=1.00). State 0 (long, reaching or surpassing the dorsalfin origin): outgroup, Brachyrhamdia, Clade D, Goeldiella, Pimelodella, R. aymarae, R. rusbyi, and Rhamdia. State 1 (short, not surpassing the tip of the first pectoral-fin ray): $R$. cainguae, $R$. eriarcha, and $R$. longiuscula. The polarity of the lengths of barbels within the family Heptapteridae is difficult to assess, given the variation from very short maxillary barbels that fall short of the base of the first pectoral-fin ray, to very long barbels that surpass the tip of the pelvic fin. Members of the basal heptapterid genera Brachyrhamdia, Goeldiella, Pimelodella, and Rhamdia have long maxillary barbels. In contrast, $R$. cainguae, R. eriarcha, and R. longiuscula have short maxillary barbels that never surpass the tip of the first (unbranched) ray of the adpressed pectoral fin (Figs. 1-4). The maxillary barbel in $R$. cainguae is apparent negatively allometric ontogenetically 
(e.g. the tip reaches the base of the pectoral-fin ray in a $88.0 \mathrm{~mm}$ SL specimen, but falls short of the posterior margin of the opercle in a $157.5 \mathrm{~mm}$ SL specimen). In contrast, the tip of maxillary barbel of $R$. aymarae reaches the end of the dorsal-fin base in a $90.0 \mathrm{~mm}$ SL specimen but only to the dorsal-fin origin in a $150 \mathrm{~mm}$ SL specimen (Miquelarena and Menni 1999). In R. rusbyi the maxillary barbel reaches the end of the dorsalfin base or slightly surpasses it in 134.2 to $183.8 \mathrm{~mm}$ SL specimens. Given the similarity among the states in $R$. aymarae and $R$. rusbyi and those exhibited by the basal heptapterid genera Brachyrhamdia, Goeldiella, Pimelodella, and Rhamdia, and the congruence among the remaining eleven synapomorphic features for $R$. cainguae, $R$. eriarcha, and $R$. longiuscula (Fig. 27, see below), the short maxillary barbel present in these three species of Rhamdella is tentatively considered to be apomorphic. Similar conditions to that of $R$. cainguae, $R$. eriarcha, and $R$. longiuscula are homoplastically present within the Clade $\mathrm{D}$ in members of Acentronichthys, Brachyglanis, Cetopsorhamdia, Chasmocranus, Gladioglanis, Leptorhamdia, Myoglanis, Pariolius, Phenacorhamdia, Rhamdioglanis, Rhamdiopsis, and Taunayia (Fig. 26).

22. Size of eye ( $s=2, c i=0.50, r i=0.66)$. State 0 (large, $20.0 \% \mathrm{HL}$ or greater): outgroup, Brachyrhamdia, Goeldiella, Pimelodella, $R$. cainguae, $R$. eriarcha, and $R$. longiuscula. State 1 (small, 16.0\% HL or lesser): Clade D, $R$. aymarae, $R$. rusbyi, and Rhamdia. Most members of the basal heptapterids Brachyrhamdia, Goeldiella, and Pimelodella typically posses large eyes, usually $20.0 \%$ HL or greater (cf. Lundberg and McDade 1986; pers. obs.). In $R$. cainguae, eye diameter in 10 males is $20.6-23.9 \%$ HL (x=22.4\%) with a bony interorbital distance of $17.9-20.3 \% \mathrm{HL}(\mathrm{x}=18.9 \%)$, whereas eye diameter in five females is $22.6-23.5 \%$ HL ( $x=23.1 \%$ ) with a bony interorbital distance of $18.2-20.7 \% \mathrm{HL}(\mathrm{x}=19.1 \%)$ (Tab. 1). In R. eriarcha, the eye diameter is $23.2 \% \mathrm{HL}$ and the bony interorbital distance is $14.9 \% \mathrm{HL}$ in one measured specimen. In $R$. longiuscula, the eye diameter is $22.5-29.4 \% \mathrm{HL}(\mathrm{x}=25.8 \%)$ and the interorbital distance is $12.8-17.7 \% \mathrm{HL}$ (x=15.0\%) in 36 specimens (Lucena and Silva 1991). The eye diameter and bony interorbital distance of $R$. aymarae and $R$. rusbyi are comparatively smaller and larger respectively than those measured in the Rhamdella species mentioned above. In $R$. aymarae, the eye diameter is $11.5-17.3 \% \mathrm{HL}(\mathrm{x}=14.6 \%)$ in 20 specimens, and the bony interorbital distance is $30.0-44.9 \%$ HL ( $\mathrm{x}=33.0 \%)$ in 19 specimens (Miquelarena and Menni 1999). The eye diameter and bony interorbital distance in four paratypes of $R$. rusbyi is $14.5-15.7 \%$ HL ( $x=15.1 \%)$ and $20.8-22.0 \%$ HL ( $x=21.3 \%)$, respectively. This state, considered apomorphic, is also exhibited by the majority of members of the Clade D (Fig. 26). An exception is Mastiglanis, a member of the Nemuroglanis sub-clade, whose eyes are relatively large (18.9-21.8\% HL, $\mathrm{x}=20.1 \%)$ (Bockmann 1994). However, this condition is probably secondarily developed in that genus. The polarity of this character within the genus Rhamdia is somewhat puzzling, since its species have either large or small eyes. Rhamdia quelen, the type species of this genus, has small eyes and wide bony interorbital distance $(14.4-15.7 \% \mathrm{HL}, \mathrm{x}=15.2 \%$ and $26.9-$ $29.8 \% \mathrm{HL}, \mathrm{x}=27.8 \%$, in 5 specimens, respectively). Rhamdia foina has very large eyes and extremely small bony interorbital distance $(22.4-22.5 \% \mathrm{HL}, \mathrm{x}=22.5 \%$ and $11.0-11.7 \% \mathrm{HL}, \mathrm{x}=11.4 \%$, in 2 specimens, respectively). However, the monophyly of the genus Rhamdia is still to be tested (Silfvergrip 1996), and is probably not supported (Bockmann, pers. obs.). Thus, state 1 is also tentatively assigned to the genus Rhamdia since $R$. quelen, the type species, has small eyes and wide bony interorbital distance.

23. A dark stripe along the lateral surface of the body ( $s=2, c i=0.50, r i=0.66)$. State 0 (absent): outgroup, Clade D, Goeldiella, $R$. rusbyi, and Rhamdia. State 1 (present): $R$. aymarae, $R$. eriarcha, $R$. cainguae, and $R$. longiuscula. State? (undetermined): Brachyrhamdia and Pimelodella. A dark stripe running along the lateral body surface seems to occur independently several times in siluriforms. Even mapping its evolution within the Heptapteridae is difficult, given that such pigmentation is present in at least some members of Acentronichthys, Brachyrhamdia, Heptapterus, Imparfinis, Mastiglanis, Nemuroglanis, Pimelodella, Rhamdella, Rhamdia, Rhamdioglanis, and Taunayia. Given that Goeldiella, probably the sister group to all other heptapterids (Bockmann 1998; Trajano and Bockmann 1999; this article), lacks a dark stripe along the lateral surface of the body, the presence of this feature in $R$. aymarae, R. cainguae (Figs. 1 and 2), R. eriarcha, and $R$. longiuscula is tentatively interpreted as derived. 
Our parsimony analysis produced one single most parsimonious tree, with 35 steps, a consistency index of 0.71 , and a retention index of 0.81 . The resulting phylogeny is presented through two cladograms: one depicting relationships among species of Rhamdella (Fig. 27) and a second representing the position of the genus Rhamdella within the family Heptapteridae (Fig. 26).

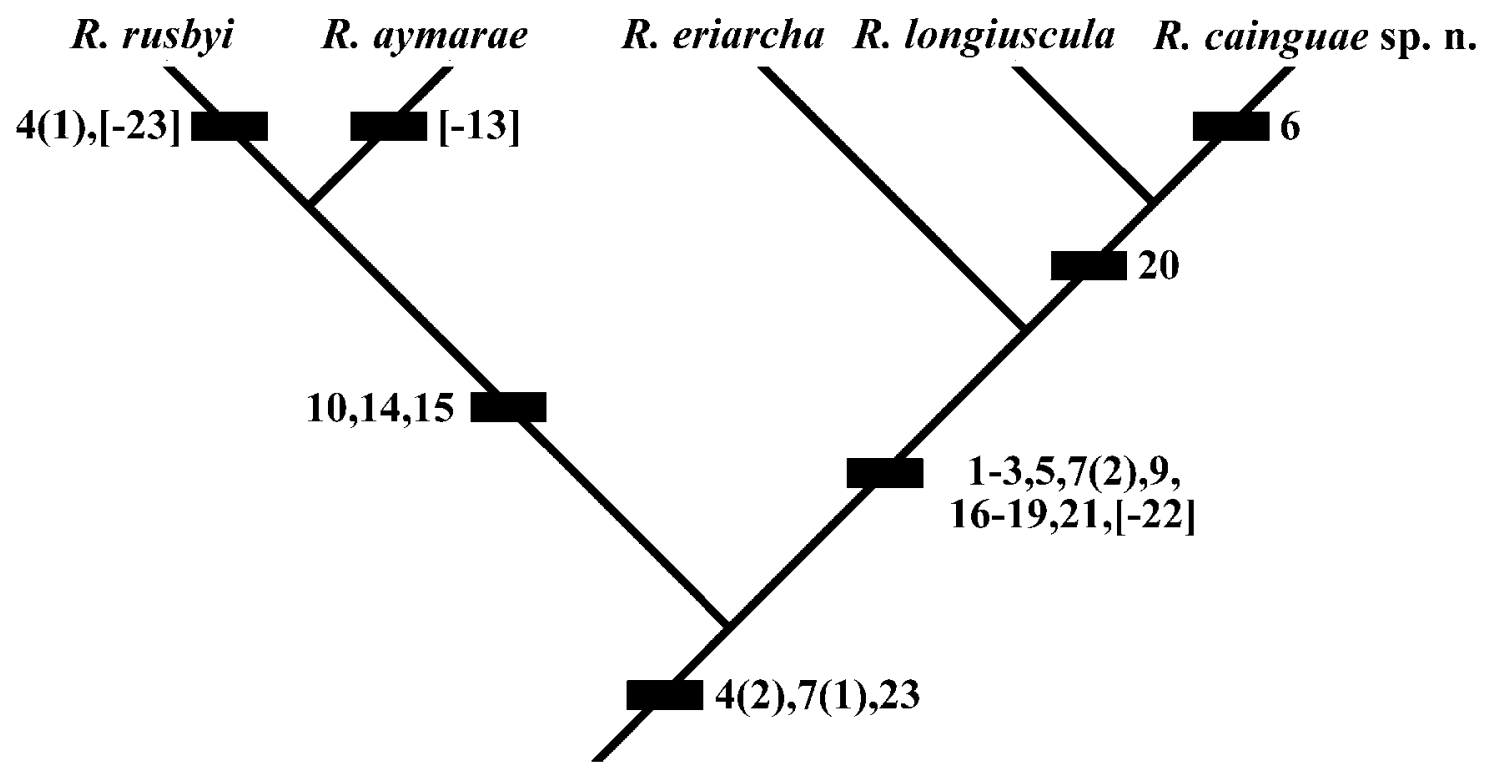

FIGURE 27. Cladogram depicting relationships among species of Rhamdella. The number of characters and their states correspond to the sequence presented in the text. Reversals are indicated by the negative numbers between brackets.

Monophyly of Rhamdella and phylogenetic relationships of R. cainguae

No previously published account has delved into the question of the monophyly of Rhamdella. To date, the genus Rhamdella was diagnosed cladistically only once, in an unpublished thesis (Bockmann 1998). That diagnosis of Rhamdella was based on examination of $R$. eriarcha, the type species, and $R$. longiuscula only. Bockmann (1998) proposed the following synapomorphies for Rhamdella: 1) optic foramen very large; 2) coronomeckelian bone elliptical; 3) orifice for exit of epiphyseal branch of supraorbital laterosensory canal very large; and 4) dark stripe along lateral line evenly deep along entire trunk. The inclusion of $R$. aymarae, $R$. cainguae, and $R$. rusbyi in the present analysis confirmed characters 1,3 , and 4 as synapomorphies for Rhamdella, but character 2 is herein considered inapplicable.

The three character states which support the monophyly of Rhamdella are (modified from Bockmann 1998): 1) opening in frontal for exit of s6 (epiphyseal) branch of supraorbital laterosensory canal much larger than openings for other supraorbital sensory branches (Character 4, State 2; Figs. 7 and 27); 2) optic foramen large, distinctly larger than foramen for trigeminofacial nerve (Character 7, State 1; Figs. 8, 22, and 27); and 3) dark stripe along the lateral surface of the body present (Character 23, State 1; Figs. 1, 2, and 27).

The very large size of the opening in the frontal for the exit of s6 (epiphyseal) branch of supraorbital laterosensory canal (Character 4, State 2; Fig. 27) occurs homoplastically in Goeldiella and reverses to a morphologically intermediate state in $R$. rusbyi (Character 4, State 1; Fig. 27). Rhamdella rusbyi is also the only Rhamdella species that lacks the apomorphic state of Character 23. According to the phylogenetic scheme for Rhamdella species obtained herein, the clade $R$. rusbyi $+R$. aymarae is the sister group of all remaining species of Rhamdella (Fig. 27). Two equally parsimonious hypotheses, both with two steps, are possible for Character 23 in Rhamdella: 1) the presence of the dark lateral stripe in $R$. aymarae and in the clade $R$. cainguae + $R$. eriarcha $+R$. longiuscula is convergent; or 2 ) the presence of a dark lateral stripe is a synapomorphy for all species of Rhamdella, with a reversal in $R$. rusbyi. The latter option is preferred because this kind of character optimization preserves the original hypothesis of primary homology (cf. de Pinna 1991). 
Rhamdella aymarae and $R$. rusbyi are hypothesized as sister species because they share three derived character states: 1) suprapreopercle well developed, forming a conspicuous ossified tubule (Character 10, State 1; Fig. 27); 2) six branchiostegal rays (Character 14, State 1; Fig. 27); and 3) 47 vertebrae (Character 15, State 1; Fig. 27). The presence of six branchiostegal rays (Character 14, State 1; Fig. 27) is homoplastic in the clade Brachyrhamdia + Pimelodella .

Monophyly of the clade composed of $R$. cainguae, $R$. eriarcha, and $R$. longiuscula is strongly corroborated by twelve derived character states: 1) anterolateral cornu of the mesethmoid short and blunt-tipped (Character 1, State 1; Figs. 7 and 27); 2) premaxilla long and narrow, with its length at midpoint approximately $45 \%$ of its width (Character 2, State 1; Figs. 8 and 27);3) posterolateral angle of the premaxilla conspicuously projected posteriorly (Character 3, State 1; Figs. 8 and 27); 4) opening for exit of s6 branch of supraorbital laterosensory canal on dorsal surface of frontal (Character 5, State 1; Figs. 7 and 27); 5) optic foramen much larger than foramen for trigeminofacial nerve (Character 7, State 2; Figs. 8, 22, and 27); 6) anteriormost portion of preoperculomandibular laterosensory canal, mainly in the lower jaw, greatly enlarged (Character 9, State 1; Figs. 10, 11, and 27); 7) anterior and posterior branches of transverse process 4 co-ossified to each other (Character 16, State 1; Figs. 15 and 27); 8) tip of transverse process of vertebra 5 expanded and branched (Character 17, State 1; Figs. 15 and 27); 9) anal-fin rays 16-18, commonly 17 (Character 18, State 1; Fig. 27); 10) hypurals 3, 4, and 5 completely co-ossified (Character 19, State 1; Figs. 19, 20, and 27); 11) maxillary barbel short, not surpassing tip of first (unbranched) pectoral-fin ray (Character 21, State 1; Figs. 1-4, and 27); and 12) eye large, 20.0\% HL or greater (Character 22, State 0; Figs. 1-4, and 27).

The apomorphic state of Character 17 in $R$. cainguae, $R$. eriarcha, and $R$. longiuscula is interpreted as homoplastic within the most parsimonious scheme of relationships (Fig. 26; see below). State 1 of Character 17 is a synapomorphy for Heptapteridae, and its reversal is synapomorphic for a large heptapterid subgroup composed of Rhamdella, Brachyglanis, Gladioglanis, Leptorhamdia, Myoglanis, plus the Nemuroglanis subclade (Ferraris 1988; Bockmann 1994), herein called Clade C (Fig. 26; see below). The presence of a small eye, with diameter $16.0 \% \mathrm{HL}$ or less, is a synapomorphy for an encompassing heptapterid group composed of Rhamdia, Rhamdella, Brachyglanis, Gladioglanis, Leptorhamdia, Myoglanis, plus the Nemuroglanis subclade (Ferraris 1988; Bockmann 1994), herein called Clade B (Fig. 26; see below). The large eye in the clade $R$. cainguae $+R$. eriarcha $+R$. longiuscula (Character 22, State 0; Fig. 27) is parsimoniously interpreted as a reversal. The lateral stripe in $R$. cainguae, $R$. eriarcha, and $R$. longiuscula is slightly more intense and welldefined than that in $R$. aymarae, and may represent an additional synapomorphy for this clade.

A hypothesis of a sister group relationship between $R$. longiuscula and $R$. cainguae is based on one derived character state: dorsal caudal-fin lobe much longer than ventral one (Character 20, State 1; Figs. 1, 2, 19, and 27).

One autapomorphy identified for Rhamdella aymarae is the presence of pharyngobranchial 1 (Character 13, State 0; Fig. 27). The absence of pharyngobranchial 1 is herein proposed as a synapomorphy for a large heptapterid clade composed of Rhamdella, Brachyglanis, Gladioglanis, Leptorhamdia, Myoglanis, plus the Nemuroglanis sub-clade (Ferraris 1988; Bockmann 1994), herein named Clade C (see below). The presence of pharyngobranchial 1 in $R$. aymarae is interpreted as a reversal.

Rhamdella cainguae has one autapomorphy: a large, differentiated ovoid area present on the supraorbital laterosensory canal located between the frontal-sphenotic boundary (Character 6, State 1; Figs. 7 and 27).

Two autapomorphies diagnose $R$. rusbyi: 1) opening in frontal for exit of s6 (epiphyseal) branch of supraorbital laterosensory canal larger than openings for other supraorbital sensory branches (Character 4, State 1; Fig. 27); and 2) dark stripe along lateral surface of the body absent (Character 23, State 0; Fig. 27). A very large opening in the frontal for exit of s6 (epiphyseal) branch of supraorbital laterosensory canal is a synapomorphy for species of Rhamdella (Character 4, State 2; Fig. 27). Therefore, intermediate size of the opening in the frontal for exit of s6 branch in $R$. rusbyi is interpreted as an autapomorphic reversal. The presence of a dark stripe along the lateral surface of the body is a synapomorphy for Rhamdella (Character 23, State 1; 
Figs. 1, 2, and 27). Thus, the condition in R. rusbyi is interpreted as an apomorphic reversal. Argumentation for the optimization of this character is presented above, in the discussion on the synapomorphies of Rhamdella.

No autapomorphies were found for $R$. eriarcha and $R$. longiuscula, which are nonetheless readily distinguishable species on the basis of their combination of characteristics.

Phylogenetic relationships of Rhamdella within Heptapteridae

The first cladistic study involving Rhamdella was that of Lundberg and McDade (1986), where the genus was assigned to an unnamed clade of the family Pimelodidae diagnosed by three synapomorphies. Lundberg et al. (1991) subsenquently named this assemblage subfamily Rhamdiinae (now called Heptapteridae - see Silfvergrip 1996) (Fig. 26). Lundberg et al. (1991) re-diagnosed the Heptapteridae with a suite of five characters, utilizing slight modifications of the three synapomorphies previously proposed by Lundberg and McDade (1986), and two new ones.

Lundberg and McDade (1986) also included Rhamdella in an unnamed subgroup of the family Heptapteridae, along with Brachyrhamdia, Cetopsorhamdia, Goeldiella, Pimelodella, Rhamdia, Typhlobagrus, Pimelodus heteropleura, and an unidentified Nannorhamdia species. This subgroup, later called Brachyrhamdia sub-clade by Ferraris (1988), shares an expanded and notched transverse process of vertebra 5 . The monophyly of the Brachyrhamdia sub-clade was not corroborated by Lundberg et al. (1991), where Rhamdella formed a basal polytomy in the Heptapteridae, together with Brachyrhamdia, Caecorhamdella, Caecorhamdia, Goeldiella, Pimelodella, Rhamdia, and Typhlobagrus.

Ferraris (1988) and Bockmann (1994) recognized another large heptapterid subset, called the Nemuroglanis sub-clade (Clade E; Fig. 26). That clade comprises Acentronichthys, Cetopsorhamdia, Chasmocranus, Heptapterus, Horiomyzon, Imparfinis, Mastiglanis, Nannoglanis, Nannorhamdia, Nemuroglanis (currently including Imparales and Medemichthys as junior synonyms - see Bockmann and Ferraris 2005), Pariolius, Phenacorhamdia, Phreatobius, Rhamdioglanis, and Rhamdiopsis, and is diagnosed on the basis of fifteen synapomorphies. A more inclusive heptapterid clade was recognized by Lundberg et al. (1991) on the basis of the reduction and loss of the free orbital rim, including the Nemuroglanis sub-clade plus Brachyglanis, Gladioglanis, Leptorhamdia, and Myoglanis (Clade D; Fig. 26). None of those studies, however, included the type species of Rhamdella, or demonstrably a closely related species.

The synapomorphies proposed by Lundberg et al. (1991) for the Heptapteridae were confirmed in Rhamdella by Bockmann (1998) and in this study (Fig. 26). The branched transverse process of vertebra 5 (Character 17, State 1; Figs. 15 and 25), considered synapomorphic for the Brachyrhamdia sub-clade by Lundberg and McDade (1986; see above), is herein re-interpreted as an autapomorphy for the Heptapteridae (Fig. 26). This character is hypothesized as reversed in the clade composed of the Nemuroglanis sub-clade plus Brachyglanis, Gladioglanis, Leptorhamdia, Myoglanis, and Rhamdella (Clade C; Fig. 26).

None of the synapomorphies for the Nemuroglanis sub-clade (Clade E; Fig. 26) and of the subgroup without a free orbital rim (Clade D; Fig. 26) were found in Rhamdella (Bockmann 1998; this study), suggesting a relatively basal position for the genus within Heptapteridae.

The present study proposes that Goeldiella is the sister group to all other Heptapteridae (Clade A; Fig. 26). Two unreversed synapomorphies diagnose the clade composed of all heptapterids except Goeldiella: 1) hypobranchial 1 rectangular (Character 11, State 1; Figs. 14, 24, and 26); and 2) hypobranchial 3 with anterolateral projection (Character 12, State 1; Figs. 14, 24, and 26).

Two synapomorphies indicate the monophyly of a new heptapterid clade composed of all genera (including Rhamdella), except Brachyrhamdia, Goeldiella, and Pimelodella (Clade B; Fig. 26): 1) supraoccipital process short, not reaching nuchal plate (Character 8, State 1; Figs. 7, 8, and 26); and 2) eye small, 16.0\% HL or less (Character 22, State 1; Fig. 26). The large eye in members of the clade Rhamdella cainguae+Rhamdella eriarcha+Rhamdella longiuscula is herein parsimoniously interpreted as a reversal (Fig. 27; see above). 
Rhamdella appears to be part of a heptapterid clade excluding Brachyrhamdia, Goeldiella, Pimelodella, and Rhamdia (Clade C; Fig. 26). Two derived character states diagnose that group: 1) pharyngobranchial 1 absent (Character 13, State 1; Fig. 26); and 2) tip of transverse process 5 simple, not branched (Character 17, State 0 ; Fig. 26). The presence of pharyngobranchial 1 (State 0 ) in $R$. aymarae is here interpreted as a reversal (Fig. 27; see above), while the absence of that structure (State 1) in Goeldiella is convergent (Fig. 26). The tip of transverse process 5 simple, not branched, is considered a reversal for Clade $\mathrm{C}$, since the expanded and branched tip of transverse process of vertebra 5 is an autapomorphy for the Heptapteridae (Fig. 26).

Even though these features do not support the monophyly of Rhamdella, they are useful to separate that genus from other basal heptapterids (Brachyrhamdia, Goeldiella, Pimelodella, and Rhamdia). Furthermore, species of Rhamdella lack the autapomorphic features of those other basal genera (see Bockmann 1998).

\section{Species compositon of Rhamdella}

The broad definition proposed by Eigenmann and Eigenmann (1888) for Rhamdella resulted in 37 nominal species being assigned to the genus since its description. Eigenmann and Eigenmann (1888) described Rhamdia eriarcha, type species of the subgenus Rhamdella, and placed Pimelodus exsudans Jenyns 1842, and Pimelodus petenensis Günther 1864, into Rhamdella. The greatest contribution to the species composition of Rhamdella was done by Eigenmann and Eigenmann (1890), who transferred 16 additional species to the genus and implemented their earlier suggestion of moving Pimelodus jenynsii Günther 1864, to Rhamdella (Eigenmann and Eigenmann 1888). Some authors also treated with taxonomic position of species that were previously described or assigned to Rhamdella (e.g. Eigenmann 1910; Fowler 1915; Gosline 1945).

Fourteen species were originally described in Rhamdella: $R$. straminea Cope 1894, R. ignobilis Steindachner 1907, R. montana Eigenmann 1913, R. leptosoma Fowler 1914, R. rusbyi Pearson 1924, R. longipinnis Borodin 1927, R. papariae Fowler 1941, R. robinsoni Fowler 1941, R. wolfi Fowler 1941, R. schultzi Miranda-Ribeiro 1964, R. lemai Bertoletti 1967, R. longiuscula Lucena and Silva 1991, R. aymarae Miquelarena and Menni 1999, and R. cainguae (this work).

Gosline (1945) listed 16 recognized species for Rhamdella (R. eriarcha, $R$. exsudans, $R$. foina, $R$. gilli, $R$. ignobilis, $R$. jenynsii, $R$. leptosoma, $R$. longipinnis, $R$. microcephala, $R$. minuta, $R$. montana, $R$. notata, $R$. papariae, $R$. robinsoni, $R$. rusbyi, and $R$. wolfi), but no diagnosis for the genus was provided. Burgess (1989) repeated the composition presented by Gosline (1945), except for adding $R$. jenynsii, and excluding $R$. foina, $R$. gilli, R. microcephala, and R. minuta. Bockmann and Guazzelli (2003) included two recently described species ( $R$. aymarae and $R$. longiuscula) in the genus and removed three others ( $R$. foina, $R$. microcephala, and $R$. minuta), following Mees (1974), Burgess (1989), Silfvergrip (1996), and Britski (2001). That specific composition was repeated with no changes by Ferraris (2007).

The unstable species composition of Rhamdella reflects in part a poor state of knowledge of phylogenetic relationships. Results of this work, examination of nominal species previously assigned to Rhamdella, and recently published information allow a redefinition of the genus. Nominal species assigned to Rhamdella and their current status are summarized in Table 3.

Silfvergrip (1996) convincingly showed that several species assigned to Rhamdella are actually junior synonyms of species of Rhamdia (Tab. 3). An exception was Rhamdia gilli, whose generic allocation was treated ambiguously in Silfvergrip (1996), either in association to Rhamdella (p. 31) or in the synonymy of Rhamdia quelen (p. 96). This was likely caused by the presence of an opened posterior fontanel in the holotype of $R$. gilli, observed by Silfvergrip (1996: 31). However, except for that character, the original description of $R$. gilli Starks (1906: 769-770, pl. 65, fig. 1) shows a fish very similar to $R$. quelen in overall appearance, and in having a relatively small-sized eye, a wide interorbital space, delicate pectoral-fin spines, and a round ventral caudal-fin lobe. For this reason, we tentatively treat that as a junior synonym of Rhamdia quelen (Tab. 3). Rhamdella straminea Cope 1894, has been considered either as a junior synonym of Rhamdella eriarcha (Malabarba 1989; Bockmann and Guazzelli 2003), or R. quelen (Lucena and Silva 1991), or even as a valid 
species of Rhamdia (Fowler 1951). Although R. straminea has a long cranial fontanel, reaching the base of the supraoccipital process, the presence of long maxillary barbels reaching the middle of ventral fins (Cope 1894) indicates that the species is not in the clade $R$. eriacha $+R$. cainguae $+R$. longiuscula. A short maxillary barbel, not surpassing the tip of the first pectoral-fin ray, is a synapomorphy for that clade (Character 21, State 1; see above). On the basis of that, plus the fact that the limit of the posterior cranial fontanel is often problematical, this species may be assigned either to Pimelodella or Rhamdia, but not to Rhamdella. This question will be treated in greater detail elsewhere (Bockmann and Sabaj, in prep.).

Examination of one syntype of Rhamdella ignobilis Steindachner 1907, and the holotype of Rhamdella longipinnis Borodin 1927, reveals that they both belong to Pimelodella, with long maxillary barbels and a sharp long supraoccipital process that contacts the predorsal plate. Rhamdella papariae, $R$. robinsoni, and $R$. wolfi, all described by Fowler (1941) from northeastern Brazil, also clearly belong to Pimelodella, given information in original descriptions and associated illustrations (e.g. slender body, large eyes, well-developed supraoccipital process, long maxillary barbel, reaching anal-fin base, robust pectoral spine, dark stripe along lateral surface of the body, etc.). Rhamdella montana Eigenmann 1913, is probably related to Pariolius, but this hypothesis needs further analysis (Bockmann, in prep.). The transfer of Nannorhamdia macrocephala Miles 1943, to Rhamdella by Miles (1945) was based on the presence of a short posterior process of the supraoccipital that does not contact the supraneural. That character state was confirmed in two paratypes of Nannorhamdia macrocephala. Although this feature is otherwise unknown in Pimelodella, N. macrocephala has long maxillary barbels, and inner caudal-fin rays that do not articulate directly on the hypural plates and with interradial membranes only along their basal halves. Bockmann (1998) considered the two latter characters as synapomorphies for Pimelodella. Fowler (1914) described Rhamdella leptosoma from the Rupununi River, Essequibo River basin, in Guyana. Despite having the dorsal caudal-fin lobe longer than the ventral lobe and, being described as having the supraoccipital process extending posteriorly as a narrow prolongation for $2 / 3$ of the distance to the dorsal fin, the overall appearance of that species is that of an elongate Pimelodella, with long maxillary barbels that reach posteriorly to the anal-fin base. Furthermore, the type locality of $R$. leptosoma is far from the known geographical distribution of Rhamdella, limited to southern South America.

Pimelodus exsudans Jenyns 1842, and Pimelodus jenynsii Günther 1864, the latter described based on the description by Jenyns (1842) of specimens identified as Pimelodus gracilis Valenciennes 1835 (= Pimelodella gracilis), are problematical species since the original descriptions are less informative concerning features necessary to ascertain their precise taxonomic positions. Both species were described as having a supraoccipital process not reaching the predorsal plate, a cranial fontanel that extends to the base of the supraoccipital, and pectoral fins with strong spines. These features probably led Eigenmann and Eigenmann $(1888,1890)$ to assign them to Rhamdella as then defined. However, we do not judge those descriptions accurate enough to warrant the states of the supraoccipital process and the cranial fontanel. Both nominal species are from Darwin's voyage to Rio de Janeiro, today one of the ichthyologically best sampled areas in the Neotropics, but where no catfish identifiable as Rhamdella has ever been reported. Species of Pimelodella and Rhamdia are common in that area, and it is possible that $P$. exsudans and $P$. jenynsii belong to those genera.

In conclusion, the genus Rhamdella, as herein delimited, includes five valid species: $R$. aymarae, $R$. cainguae, $R$. eriarcha, $R$. longiuscula, and $R$. rusbyi. According to previous conceptions of Rhamdella, that genus was widely distributed from Central America to southern South America. The distribution of Rhamdella is restricted herein to the Río Beni basin in the Bolivian portion of the Rio Amazonas drainage, the endorheic Río Itiyuro basin in northern Argentina, and the Rio Uruguay and Rio Jacuí systems in southern Brazil. Although monophyly of Rhamdella is based on three features only (being two reversals), the clade composed of $R$. cainguae, $R$. eriarcha (the type species of Rhamdella), and $R$. longiuscula is strongly corroborated. It will not be a surprise if this genus is restricted to these three species only after a more comprehensive study. 


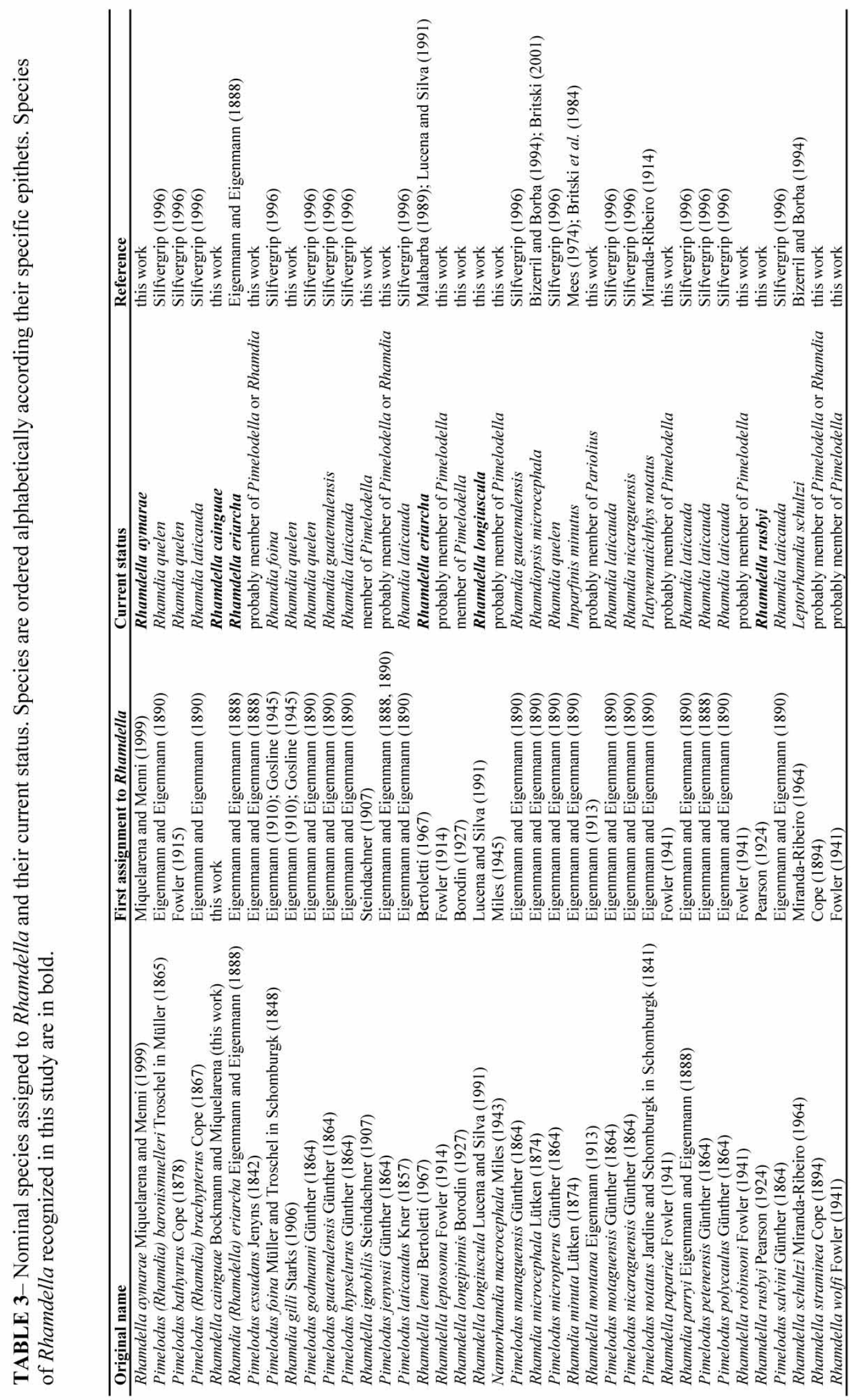




\section{Acknowledgments}

We are grateful to the following individuals for allowing us to examine material under their care: Radford Arrindel, Barbara A. Brown, Norma Feinberg, Xenia Freilich, Scott A. Schaefer, and Melanie L. J. Stiassny (AMNH); Anne-Marie Woolger (BMNH); David Catania, William N. Eschmeyer, and Tomio Iwamoto (CAS); Barry Chernoff, Mary Anne Rogers, and Mike Westneat (FMNH); Carlos A. S. Lucena, Zilda Margarete S. Lucena, Luiz R. Malabarba, José F. Pezzi da Silva, and Roberto E. Reis (MCP); Arion T. Aranda, Paulo A. Buckup, and Gustavo W. Nunan (MNRJ); Heraldo A. Britski, José L. de Figueiredo, Naércio A. Menezes, Osvaldo T. Oyakawa, and Mário C. C. de Pinna (MZUSP); Barbara Herzig and Ernst Mikschi (NMW); Wilson J. E. M. Costa (UFRJ); William L. Fink and Doug W. Nelson (UMMZ); Jeffrey Clayton, Susan L. Jewett, Lisa F. Palmer, Lynne R. Parenti, Sandra J. Raredon, Richard P. Vari, and Stanley H. Weitzman (USNM), and Jørgen G. Nielsen (ZMUC). David Catania and José F. Pezzi da Silva also kindly examined specimens for us that are deposited in their respective institutions. Thanks are also due to Ramiro Filiberto, Hugo López, Lucila Protogino, and Marcelo Montenegro for help in field work. Murilo de Carvalho and Aléssio Datovo helped us in editing figures. The manuscript benefited greatly from comments and suggestions by Adriana E. Aquino, John G. Lundberg, Richard P. Vari, and an anonymous reviewer. Particularly thorough reviews were done by Marcelo R. de Carvalho and Mário C. C. de Pinna, for which we are especially grateful. Ronaldo Fernandes, Ulisses Caramaschi, and José Pombal Jr., provided valuable laboratory assistance for FAB at MNRJ. Part of this study was developed by FAB during a Doctoral Program at the Universidade de São Paulo, MZUSP, supported by Fundação de Amparo à Pesquisa do Estado de São Paulo (FAPESP), State of São Paulo Government (Proc. No. 92/04004-2 and 94/02816-5), under guidance of Heraldo A. Britski. Additional support was provided by FAPESP (Proc. No. 01/03220-4, 03/03108-5) and a Post-Doctoral tenure at MNRJ, supported by Fundação Carlos Chagas Filho de Amparo à Pesquisa do Estado do Rio de Janeiro (FAPERJ), State of Rio de Janeiro Government (Proc. No. E-26/150.821/1999). This article is a contribution of the "All Catfish Species Inventory" Project (NSF DEB 0315963). Research funding for this study came from CNPq (Proc. No. 307248/2004-6 to FAB). FAB is very grateful to Adriana M. Saur for her support during all stages of this study.

\section{Literature cited}

Arratia, G. (1987) Description of the primitive family Diplomystidae (Siluriformes, Teleostei, Pisces): morphology, taxonomy and phylogenetic implications. Bonner Zoologische Monographien, no. 24, 1-120.

Arratia, G. (1992) Development and variation of the suspensorium of primitive catfishes (Teleostei: Ostariophysi) and their phylogenetic relationships. Bonner Zoologische Monographien, no. 32, 1-149.

Arratia, G. \& Gayet, M. (1995) Sensory canals and related bones of Tertiary siluriform crania from Bolivia and North America and comparison with Recent forms. Journal of Vertebrate Paleontology, 15, 482-505.

Arratia, G. and Huaquin, L. (1995) Morphology of the lateral line system and of the skin of diplomystid and certain primitive loricarioid catfishes and systematic and ecological considerations. Bonner Zoologische Monographien, no. 36, $1-110$.

Azpelicueta, M.M. (1994) Three East-Andean species of Diplomystes (Siluriformes: Diplomystidae). Ichthyological Exploration of Freshwaters, 5, 223-240.

Bertoletti, J.J. (1967) Nova espécie de "Rhamdella" Eigenmann and Eigenmann (Actinopterygii, Siluriformes, Pimelodidae). Revista Brasileira de Biologia, 27, 77-83.

Bizerril, C.R.S.F. \& Borba, I.M.M. (1994) Status taxonômico de Rhamdella schultzi Ribeiro, 1964 (Siluriformes, Pimelodidae). Boletim do Museu Nacional, Nova Série, zoologia, no. 357, 1-6.

Bockmann, F.A. (1994) Description of Mastiglanis asopos, a new pimelodid catfish from northern Brazil, with comments on phylogenetic relationships inside the subfamily Rhamdiinae (Siluriformes: Pimelodidae). Proceedings of the Biological Society of Washington, 107, 760-777.

Bockmann, F.A. (1998) Análise Filogenética da Família Heptapteridae (Teleostei, Ostariophysi, Siluriformes) e Redefenição de seus Gêneros. Unpublished Ph.D. thesis, Universidade de São Paulo, São Paulo. 
Bockmann, F.A. \& Ferraris, C.J., Jr. (2005) Systematics of the Neotropical catfish genera Nemuroglanis Eigenmann and Eigenmann 1889, Imparales Schultz 1944, and Medemichthys Dahl 1961 (Siluriformes: Heptapteridae). Copeia, 2005, 124-137.

Bockmann, F.A. \& Guazzelli, G.M. (2003) Heptapteridae (Heptapterids). In: Reis, R. E., Kullander, S. O. and Ferraris, C. J., Jr. (Eds.), Check List of the Freshwater Fishes of South and Central America. Edipucrs, Porto Alegre, Brazil, pp. 406-431.

Borodin, N.A. (1927) Some new catfishes from Brazil. American Museum Novitates, no. 266, 1-7.

Britski, H.A. (2001) Sobre a obra Velhas-Flodens Fiske [Peixes do Rio das Velhas]. In: Alves, C. B. M. and Pompeu, P. S. (Orgs.), Peixes do Rio das Velhas: Passado e Presente. Incluindo a Tradução da Monografia Velhas-Flodens Fiske, 1875, de Chr. Fr. Lütken. SEGRAC, Belo Horizonte, Brazil, pp. 16-22.

Britski, H.A., Sato, Y. \& Rosa, A.B.S. (1984) Manual de Identificação de Peixes da Região de Três Marias (com Chaves de Identificação para os Peixes da Bacia do São Francisco). CODEVASF, Brasília, 143 p.

Buckup, P.A. (1988) The genus Heptapterus (Teleostei, Pimelodidae) in southern Brazil and Uruguay, with the description of a new species. Copeia, 1988, 641-653.

Burgess, W.E. (1989) An Atlas of Freshwater and Marine Catfishes. A Preliminary Survey of the Siluriformes. T.F.H. Publications, Neptune City, New Jersey, 784 p.

Chardon, M. (1968) Anatomie comparée de l'appareil de Weber et structures connexes chez les Siluriformes. Annales du Musée Royal de l'Afrique Centrale, Series in 8', Sceances Zoologiques, no. 169, 1-277.

Cope, E.D. (1867) Supplement on some new species of American and African fishes. Transactions of the American Philosophical Society, 13, 400-407.

Cope, E.D. (1878) Synopsis of the fishes of the Peruvian Amazon, obtained by Professor Orton during his expeditions of 1873 and 1877. Proceedings of the American Philosophical Society, 17, 673-701.

Cope, E.D. (1894) On the fishes obtained by the Naturalist Expedition in Rio Grande do Sul. Proceedings of the American Philosophical Society, 33, 84-108, pls. 4-9.

Dingerkus, G. \& Uhler, L.D. (1977) Enzyme clearing of alcian blue stained whole small vertebrates. Stain Technology, $52,229-232$.

Eigenmann, C.H. (1910) Catalogue of the fresh-water fishes of Tropical and South Temperate America. Reports of the Princeton University Expeditions to Patagonia 1896-1899, Zoology, vol. 3, pt. 2. Princeton University, pp. $375-511$.

Eigenmann, C.H. (1912) The freshwater fishes of British Guiana, including a study of the ecological grouping of species, and the relation of the fauna of the plateau to that of the lowlands. Memoirs of the Carnegie Museum, 5, $\mathrm{i}-\mathrm{xxii}+1-$ 578, pls. $1-103$.

Eigenmann, C.H. (1913) On two new species of fishes collected by Miss Lola Vance in Peru. Annals of the Carnegie Museum, 8, 421-422, pl. 32.

Eigenmann, C.H. \& Eigenmann, R.S. (1888) Preliminary notes on South American Nematognathi, I. Proceedings of the California Academy of Sciences, Series 2, 1, 119-172.

Eigenmann, C.H. \& Eigenmann, R.S. (1890) A revision of the South American Nematognathi or cat-fishes. Occasional Papers of the California Academy of Sciences, no. 1, 1-508 + errata and map.

Farris, J.S. (1988) Hennig86, version 1.5. Computer Program and Reference Manual. Distributed by the author, Port Jefferson Station.

Ferraris, C.J., Jr. (1988) Relationships of the Neotropical catfish genus Nemuroglanis, with a description of a new species (Osteichthys: Siluriformes: Pimelodidae). Proceedings of the Biological Society of Washington, 101, 509-516.

Ferraris, C.J., Jr. (2007) Checklist of catfishes, recent and fossil (Osteichthyes: Siluriformes), and catalogue of siluriform primary types. Zootaxa, 1418, 1-628.

Ferraris, C.J., Jr. \& Mago-Leccia, F. (1989) A new genus and species of pimelodid catfish from the Río Negro and Río Orinoco drainages of Venezuela (Siluriformes: Pimelodidae). Copeia, 1989, 166-171.

Fink, S.V. \& Fink, W.L. (1981) Interrelationships of the ostariophysan fishes (Teleostei). Zoological Journal of the Linnean Society, 72: 297-353.

Fink, S.V. \& Fink, W.L. (1996) Interrelationships of ostariophysan fishes (Teleostei). In: Stiassny, M. L. J., Parenti, L. R. and Johnson, G. D. (Eds.), Interrelationships of Fishes. Academic Press, San Diego, pp. 209-249.

Fowler, H.W. (1914) Fishes from the Rupununi River, British Guiana. Proceedings of the Academy of Natural Sciences, Philadelphia, 66, 229-284.

Fowler, H.W. (1915) Notes on nematognathous fishes. Proceedings of the Academy of Natural Sciences, Philadelphia, 67, 203-243.

Fowler, H.W. (1941) A collection of fresh-water fishes obtained in eastern Brazil by Dr. Rodolpho von Ihering. Proceedings of the Academy of Natural Sciences, Philadelphia, 93, 123-199.

Fowler, H.W. (1951) Os peixes de água doce do Brasil (3. ${ }^{a}$ entrega). Arquivos de Zoologia do Estado de São Paulo, 6, 405-624.

Gill, T.N. (1872) Arrangement of the families of fishes, or classes Pisces, Marsipobranchii, and Leptocardii. Smithsonian Miscellaneous Collection, no. 247, 1-49. 
Gosline, W.A. (1945) Catálogo dos nematognatos de água-doce da América do Sul e Central. Boletim do Museu Nacional, Nova série, Zoologia, no. 33, 1-138.

Günther, A. (1864) Catalogue of the Fishes in the British Museum, vol. 5.-Catalogue of the Physostomi, Containing the Families Siluridae, Characinidae, Haplochitonidae, Sternoptychidae, Scopelidae, Stomiatidae in the Collection of the British Museum. Trustees, London, xxii +455 p.

Jenyns, L. (1842) Part IV, Fish. In: Darwin, C. (Ed.), 1840-1842, The Zoology of the Voyage of H. M. S. Beagle, Under the Command of Captain Fitzroy, R. N., During the Years 1832 to 1836. Smith, Elder, and Co., Cornhill, pp. 97-172.

Kner, R. (1857) Ichthyologische beiträge. II Abtheilung. Sitzungsberichten der kaiserlichen Akademie der Wissenschaften, mathematisch-naturwissenschaftlichen Klasse, 26, 373-448, pls. 1-9.

López, H.L., Miquelarena, A.M. \& Menni, R.C. (2003) Lista Comentada de los Peces Continentales de la Argentina (ProBiota, Série Técnica y Didáctica, no. 5). Museo de La Plata, Buenos Aires, Argentina, 85 p.

Lucena, C.A.S. \& da Silva, J.F.P. (1991) Descrição de uma nova espécie do gênero Rhamdella Eigenmann \& Eigenmann, 1888 (Siluriformes: Pimelodidae) para o médio rio Uruguai, sul do Brasil. Comunicações do Museu de Ciências da PUCRS, Série Zoologia, Porto Alegre, 4, 28-47.

Lundberg, J.G. (1975) Homologies of the upper shoulder girdle and temporal bones in catfishes (Order Siluriformes), with comments on the skull of the Helogeneidae. Copeia, 1975, 66-74.

Lundberg, J.G. \& Baskin, J.N. (1969) The caudal skeleton of the catfishes, order Siluriformes. American Museum Novitates, no. 2398, 1-49.

Lundberg, J.G., Bornbusch, A.H. \& Mago-Leccia, F. (1991) Gladioglanis conquistador n. sp. from Ecuador with diagnoses of the subfamilies Rhamdiinae Bleeker and Pseudopimelodinae n. subf. (Siluriformes: Pimelodidae). Copeia, 1991, 190-209.

Lundberg, J.G. \& McDade, L.A. (1986) On the South American catfish Brachyrhamdia imitator Myers (Siluriformes, Pimelodidae), with phylogenetic evidence for a large intrafamilial lineage. Notulae Naturae (Philadelphia), no. 463, $1-24$.

Lütken, C.F. (1874) Siluridae novae Brasiliae centralis a clarissimo J. Reinhardt in provincia Minas-geraës circa oppidulum Lagoa Santa, praecipue in flumine Rio das Velhas et affluentibus collectae, secundum caracteres essentiales, breviter descriptae. Oversigt over Selskabets verksomhed, Kongelige Danske Videnskabernes selskab., Kjobenhavn, 1873, 29-36.

Malabarba, L.R. (1989) Histórico sistemático e lista comentada das espécies de peixes de água doce do sistema da Laguna dos Patos, Rio Grande do Sul, Brasil. Comunicações do Museu de Ciências da PUCRS, Série Zoologia, Porto Alegre, 2, 107-179.

Maslin, T.P. (1952) Morphological criteria of phyletic relationships. Systematic Zoology, 1, 49-70.

Mees, G.F. (1967) Freshwater fishes of Suriname: the genus Heptapterus (Pimelodidae). Zoologische Mededelingen (Leiden), 42, 215-229.

Mees, G.F. (1974) The Auchenipteridae and Pimelodidae of Suriname (Pisces, Nematognathi). Zoologische Verhandelingen (Leiden), no. 132, 1-256, pls. 1-15.

Miles, C. (1943) Estudio Economico y Ecologico de Los Peces de Agua Dulce del Valle de Cauca. Departamento del Valle de Cauca, Cali, Colombia, 97 p.

Miles, C. (1945) Some newly recorded fishes from the Magdalena River system. Caldasia, 3, 453-464.

Miquelarena, A.M. \& Menni, R.C. (1999) Rhamdella aymarae, a new species from the Itiyuro River, northern Argentina (Siluriformes: Pimelodidae). Ichthyological Exploration of Freshwaters, 10, 201-210.

Miranda Ribeiro, A. (1914) Pimelodidae, Trachycorystidae, Cetopsidae, Bunocephalidae, Auchenipteridae, e Hypophthalmidae. In: Commissão de Linhas Telegraphicas Estrategicas de Matto-Grosso ao Amazonas, Matto-Grosso, Annexo no. 5 (Historia Natural: Zoologia). 1-13 p., pls. 1-2.

Miranda Ribeiro, P. (1964) Rhamdella schultzi sp. nov. (Pisces - Siluriformes - Pimelodidae). Boletim do Museu Nacional, Nova Série, zoologia, no. 248, 1-4.

Mo, T. (1991) Anatomy, Relationships and Systematics of the Bagridae (Teleostei: Siluroidei) with a Hypothesis of Siluroid Phylogeny (Theses Zoologicae, 17). Koeltz, Koenigstein, 216 p., 63 figs.

Müller, J. (1865) Reisen in den Vereinigten Staaten, Canada und Mexico. 3 vols. [1864-65]. F. A. Brockhaus, Leipzig.

Northcutt, G. (1989) The phylogenetic distribution and innervation of craniate mechanoreceptive lateral lines. In: Coombs, S. P., Görner, P. and Münz, H. (Eds.), The Mechanosensory Lateral Line. Springer, New York, pp. 17-78.

Pearson, N.E. (1924) The fishes of the eastern slope of the Andes. I. - The fishes of the Rio Beni basin, Bolivia, collected by the Mulford expedition. Indiana University Studies, 11, 1-83, pls. 1-12.

de Pinna, M.C.C. (1991) Concepts and tests of homology in the cladistic paradigm. Cladistics, 7, 367-394.

de Pinna, M.C.C. (1993) Higher-level Phylogeny of Siluriformes (Teleostei: Ostariophysi), with a New Classification of the Order. Unpublished Ph.D. dissertation, City University of New York, New York.

de Pinna, M.C.C. \& Vari, R.P. (1995) Monophyly and phylogenetic diagnosis of the family Cetopsidae, with synonymization of the Helogenidae (Teleostei: Siluriformes). Smithsonian Contributions to Zoology, no. 571, i-iii + 1-26.

Pollard, H.B. (1892) The lateral system in siluroids. Zoologischen Jahrbüchern, 5, 525-551. 
Ramos, T.C. (1997) Tree Gardener, version 2.1. Computer Program and Reference Manual. Distributed by the author, São Paulo, Brazil.

Regan, C.T. (1911) The classification of the teleostean fishes of the order Ostariophysi. 2. Siluroidea. Annals and Magazine of Natural History (Ser. 8), 8, 553-577.

Ringuelet, R.A. (1975) Zoogeografía y ecología de los peces de agua continentales de la Argentina y consideracionaes sobre las áreas ictiológicas de América del Sur. Ecosur, 2, 1-121.

Sands, D.D. (1985) Catfishes of the World. Volume Three: Supplements (first set). Dunure Enterprises, Dunure.

Schomburgk, R.H. (1841) The Natural History of Fishes of Guiana.-Part I. The Naturalists' Library. Vol. 3, W. H. Lizars, Edinburgh, 263 p., pls. 1-30.

Schomburgk, R.H. (1848) Reisen in Britisch-Guiana in den Jahren 1840-1844. Im Auftrag Sr. Mäjestat des Königs von Preussen ausgeführt von Richard Schomburgk. Versuch einer Fauna und Flora von Britisch-Guiana. Nach Vorlagen von Johannes Muller, Ehrenberg, Erichson, Klotzch, Troschel, Cabanis und Andern, Leipzig.

Schultz, L.P. (1944) The catfishes of Venezuela, with descriptions of thirty-eight new forms. Proceedings of the United States National Museum, 94, 173-338, pls. 1-14.

Silfvergrip, A.M.C. (1996) A Systematic Revision of the Neotropical Catfish Genus Rhamdia (Teleostei, Pimelodidae). Stockholm University, Stockholm, 156 p., 8 pl.

Starks, E.C. (1906) On a collection of fishes made by P. O. Simons in Ecuador and Peru. Proceedings of the United States National Museum, 30, 761-800, pls. 65-66.

Steindachner, F. (1907) Über einige Fischarten aus dem Flusse Cubataõ im Staate Santa Catharina bei Theresopolis (Brasilien). Sitzungsberichten der kaiserlichen Akademie der Wissenschaften, mathematisch-naturwissenschaftichen Klasse, Wien, Abt. 1, Botanik, Zoologie, Anatomie, Geologie und Paläontologie, 116, 475-492, pls. 1-2.

Taylor, W.R. \& Van Dyke, G.C. (1985) Revised procedures for staining and clearing small fishes and other vertebrates for bone and cartilage study. Cybium, 9, 107-119.

Trajano, E. \& Bockmann, F.A. (1999) Evolution of ecology and behaviour in Brazilian heptapterine cave catfishes, based on cladistic analysis (Teleostei: Siluriformes). Mémoires de Biospéologie, 26, 123-129. 


\section{Appendix}

Comparative material of Heptapteridae is listed below. Specimens are alcohol preserved, except when noted.

Acentronichthys leptos: UFRJ 313, 1 ex. (26.3 mm SL), UFRJ 505, 1 ex. C \& S (68.7 mm SL), Brazil, State of Rio de Janeiro, stream crossing road Estrada dos Bandeirantes, Jacarepaguá.

Brachyglanis frenata: AMNH 74397, 87 ex. in alcohol (32.4-98.6 mm SL) and 2 ex. C \& S (55.5-58.4 mm SL), Venezuela, Territorio Federal Amazonas, Departamento Río Negro, Río Mawarinuma, 1 km upriver from Cerro de Neblina base camp ( $\left.00^{\circ} 55^{\prime} \mathrm{N} 66^{\circ} 10^{\prime} \mathrm{W}\right)$.

Brachyrhamdia imitator: MCP 15132, 8 ex. (34.8-40.8 mm SL) and 2 ex. C \& S (30.8-34.4 mm SL), Venezuela, State of Bolívar, porto Las Majadas in Río Caura $\left(07^{\circ} 30^{\prime} 18^{\prime \prime} \mathrm{N} 64^{\circ} 50^{\prime} 24^{\prime \prime} \mathrm{W}\right)$.

Brachyrhamdia marthae: USNM 305631, 40 ex. (26.1-32.9 mm SL) and 2 ex. C \& S (31.5-32.5 mm SL), Bolivia, Departamento Beni, at $1.5 \mathrm{~km}$ W Río Matos, crossing $45 \mathrm{~km}$ E San Borja, Río Mamoré basin; USNM 305864, 38 ex. (28.4-43.3 mm SL) and 2 ex. C \& S (30.5-36.2 mm SL), Bolivia, Departamento Beni, E. E. B. Camp Trapiche La Pascana, antiguo curro del Río Maniqui.

Brachyrhamdia meesi: UFRJ 397, 2 ex. C \& S (43.1-45.2 mm SL), material from aquarium.

Cetopsorhamdia boquillae: CAS 63607, 4 ex. (42.4-59.1 mm SL) and 1 ex. C \& S (52.9 mm SL), paratypes, Colombia, Río Quindío, Boquilla.

Cetopsorhamdia iheringi: MZUSP 47950, 45 ex. (23.5-75.4 mm SL) and 3 ex. C \& S (46.2-65.4 mm SL), Brazil, State of São Paulo, Botucatu, Rio Capivara, in farm Indiana, in the region of Depressão Periférica, Rio Paranapanema basin; MZUSP 37158, 61 ex. (26.2-67.6 mm SL) and 3 ex. C \& S (56.8-57.9 mm SL), Brazil, State of Minas Gerais, município de Moeda, Pedra Vermelha, affluent of the Rio Paraopeba, km 10 on road BR-040/Moeda (Rio São Francisco basin).

Gladioglanis conquistador: MZUSP 45906, 2 ex. C \& S (28.6-30.8 mm SL), Brazil, State of Amazonas, Lago Miuá, above Codajás.

Gladioglanis machadoi: MZUSP 28052, 8 ex. (20.2-26.6 mm SL) and 1 ex. C \& S (27.3 mm SL), Brazil, State of Amazonas, Moura, Rio Negro, Pedra do Gavião.

Goeldiella eques: MZUSP 45907, 1 ex. C \& S (78.5 mm SL), Brazil, State of Pará, Rio Amazonas system, Lago Jacaré, Rio Trombetas, cabeceira da Serrinha, in Reserva Biológica de Trombetas; USNM 270036, 6 ex. in alcohol (92.8$113.8 \mathrm{~mm} \mathrm{SL})$ and 1 ex. C \& S (93.1 mm SL), Venezuela, Territorio Federal Amazonas, Departamento Rio Negro, Caño Manú, tributary of Casiquare canal, approximately 250 m upstream from Solano $\left(02^{\circ} 00^{\prime} \mathrm{N} 066^{\circ} 57^{\prime} \mathrm{W}\right)$.

Heptapterus mustelinus: UFRJ 712, 1 ex. C \& S (93.6 mm SL), Brazil, State of Santa Catarina, Nova Veneza, stream affluent of Rio São Bento (Rio Araranguá basin).

“Imparales" panamensis: USNM 308587, 4 ex. (36.8-49.3 mm SL) and 1 ex. C \& S (54.4 mm SL), Panama, Panama Province, Río Frijoles above Pipeline Road N of Gamboa (Río Chagres drainage).

Imparfinis borodini: MZUSP 40618, 35 ex. in alcohol (36.8-153.4 mm SL) and 2 ex. C \& S (73.3-84.3 mm SL), Brazil, State of Goiás, São Domingos, Córrego Bonito, Rio São Domingos drainage (Rio Tocantins basin), below bridge on the road GO-110.

Imparfinis guttatus: USNM 305541, 5 ex. in alcohol and 1 ex. C \& S (85.1 mm SL), Bolivia, Departament of Beni, Ballivia Prov., Rio Curiraba at $10 \mathrm{Km}$ Ne El Porvenir Biological Station, at 40 air km E San Borja (Río Mamoré basin) $\left(14^{\circ} 55^{\prime} \mathrm{S} 066^{\circ} 17^{\prime} \mathrm{W}\right)$.

Imparfinis hollandi: FMNH 54244, 1 ex. (230.0 mm SL), holotype, [Brazil, State of Paraná], Porto União da Victoria, Rio Iguassú [=Rio Iguaçu].

Imparfinis longicaudus: BMNH 1880.12.8.100-104, 4 ex. (75.2-116.5 mm SL), syntypes of Pimelodus (Rhamdia) longicauda, Canelos (Río Napo basin).

Imparfinis minutus: ZMUC 325x, 1 ex. (71.8 mm SL), syntype of Rhamdia minuta, Rio das Velhas and Quebra-brook, Brazil; ZMUC 328, 1 ex. (64.1 mm SL), syntype of Rhamdia minuta, Rio das Velhas and Quebra-brook, Brazil.

Imparfinis nemacheir: USNM 121170, 10 ex. in alcohol (37.0-61.7 mm SL) and 2 ex. C \& S (51.2-63.5 mm SL), Venezuela, Río San Pedro at bridge, Río Motatan system, Maracaibo basin.

Imparfinis schubarti: MZUSP 45897, 1 ex. (73.8 mm SL), Brazil, State of Goiás, Mineiros, Rio Verde basin, stream on road Mineiros/Taquari.

Leptorhamdia nocturna: MZUSP 45895, 1 ex. C \& S (70.9 mm SL), Brazil, State of Amazonas, Rio Negro, just downriver from Rio Daraá.

Leptorhamdia schultzi: MNRJ 9549, 1 ex. (94.0 mm SL), holotype of Rhamdella schultzi, [Brazil, State of Mato Grosso?], Alto Rio Xingú [=upper course of Rio Xingu, Rio Xingu basin, Rio Amazonas system].

Mastiglanis asopos: MZUSP 44215, 1 ex. C \& S (52.0 mm SL), paratype, Brazil, State of Amazonas, Rio Daraá (tributary of Rio Negro), Cachoeira do Aracu.

Myoglanis sp.: AMNH 74407, 9 ex. (45.6-119.3 mm SL) and 2 ex. C \& S (70.0-82.3 mm SL), Venezuela, Territorio 
Federal Amazonas, Departamento Río Negro, tributary $10 \mathrm{~km}$ upriver from Río Mawarinuma, $5 \mathrm{~km}$ E from Cerro de Neblina base camp.

"Nannorhamdia" macrocephala: USNM 120157, 2 ex. (22.0-26.8 mm SL), paratypes of Nannorhamdia macrocephala, Colombia, Río Cauca, in Juanchito, Cali.

Nannorhamdia stictonotus: MCP 15613, 7 ex. (20.1-42.9 mm SL), Brazil, State of Mato Grosso, Jauquara, Barra do Bugres, Rio Jauquara, an affluent of the Rio dos Pássaros (Rio Paraguay basin).

Nemuroglanis lanceolatus: MZUSP 23412, 3 ex. (12.9-38.1 mm SL) and 1 ex. C \& S (34.6 mm SL), Brazil, State of Amazonas, igarapé Tucuxi (affluent of Rio Auati-Paraná, Rio Japurá drainage, Rio Amazonas basin), northwest of Fonte Boa.

Nemuroglanis pauciradiatus: MZUSP 45908, 2 ex. C \& S (28.4-28.5 mm SL), Brazil, State of Amazonas, Silves, Rio Sanabani (Rio Amazonas basin).

Pariolius armillatus: CAS 134168-134170 and 134172, 2 ex. and 2 ex. C \& S (18.9-30.6 mm SL), Peru, Departamento Loreto, Río Ampiyacu (Río Amazonas basin), near Pebas.

Phenacorhamdia boliviana: MZUSP 42296, 2 ex. C \& S (56.0-70.5 mm SL), Bolivia, Departamento Cochabamba, Villa Tunari, Río Chapare (Río Mamoré drainage).

Phenacorhamdia unifasciata: MZUSP 36701, 1 ex. C \& S (56.7 mm SL), paratype, Brazil, Distrito Federal, Rio São Bartolomeu basin (upper Rio Paraná basin).

Phenacorhamdia sp.: MZUSP 37159, 23 ex. and 5 ex. C \& S (51.5-67.1 mm SL), Brazil, State of Minas Gerais, município de Moeda, Pedra Vermelha, stream on km 10 of road BR-040/Moeda (Rio Paraopeba drainage, Rio São Francisco basin).

Phreatobius cisternarum: MNRJ 11569, 1 ex. C \& S (55.0 mm SL), Brazil, State of Amapá, in Macapá, in mouth of Rio Amazonas.

Pimelodella australis: MZUSP 25033, 252 ex. and 5 ex. C \& S (50.9-58.5 mm SL), Brazil, State of Rio Grande do Sul, Belém Novo, Arroio Chapéu Virado.

Pimelodella cristata: AMNH 220410, 8 ex. (81.0-160.0 mm SL), Guyana, Essequibo River, Kartabo; AMNH 39985, 20 ex. (52.0-195.0 mm SL); Bolivia, Beni, Río Baures, at mouth.

Pimelodella laticeps: ILPLA 616, 1 ex. C \& S (68.7 mm SL), Argentina, El Pescado stream, near La Plata.

Pimelodella sp.: UFRJ 502, 2 ex. C \& S (60.3-62.4 mm SL), Brazil, State of Mato Grosso, in affluent of Rio Cinta Larga, affluent of Rio Aripuanã, Rio Madeira basin, Rio Amazonas system, on road BR-174; UFRJ 503, 2 ex. C \& S (32.0$89.5 \mathrm{~mm}$ SL), Brazil, State of Minas Gerais, Ipatinga, Rio Cachoeira, Rio Doce basin.

"Pimelodus" heteropleurus: USNM 226105, 71 ex. in alcohol (26.8-36.1 mm SL) and 2 ex. C \& S (32.5-32.7 mm SL), Suriname, Nickerie District, tributary of Sisa Creek, north side, approximately $700 \mathrm{~m}$ downstream of crossing of Amotopo to Camp Geologie Road $\left(03^{\circ} 42^{\prime} \mathrm{N} 057^{\circ} 42^{\prime} \mathrm{W}\right)$.

Rhamdella aymarae: ILPLA 611, 1 ex. (120.4 mm SL), holotype, Argentina: Salta Province, Río Itiyuro, $500 \mathrm{~m}$ below Itiyuro Dam, route 34 between Estación Pocitos and Araguay; ILPLA 612, 30 ex. (88.8-188.0 mm SL), paratypes, same data as holotype; ILPLA 613, 31 ex. (60.0-151.0 mm SL), paratypes, same data as holotype; ILPLA 614, 5 ex. C \& S (77.0-124.0 mm SL), paratypes, same data as holotype.

Rhamdella eriarcha: MCP 8701, 1 ex. C \& S (96.8 mm SL), Brazil, State of Rio Grande do Sul, Porto Alegre, Rio Guaíba, in Ponta Grossa; MCP 14433, 2 ex. (109.0-168.5 mm SL), Brazil, State of Rio Grande do Sul, Porto Alegre, Rio Guaiba, in Ponta Grossa; MCP 11587, 2 males (157.5-116.0 mm SL), Brazil, State of Rio Grande do Sul, Porto Alegre, Rio Guaíba, in Ponta Grossa; MCP 16289, 1 ex. (74.3 mm SL), Brazil, State of Rio Grande do Sul, Caçapava do Sul, Arroio Pessegueiro (Rio Jacuí system), in Passo do Megatério; MCP 26978, 5 males (127.0-151.7 mm SL), Brazil, State of Rio Grande do Sul, Arroio do Tigre, Rio Jacuí, upriver from UHE Itaúba dam (29¹5'46”S $\left.053^{\circ} 14^{\prime} 5^{\prime \prime W}\right)$; MCP 26544, 1 ex. C \& S (98.7 mm SL), Brazil, State of Rio Grande do Sul: Agudo, Rio Jacuí, upriver from UHE Dona Francisca $\left(29^{\circ} 31^{\prime} \mathrm{S} 53^{\circ} 16^{\prime} \mathrm{W}\right)$.

"Rhamdella" ignobilis: NMW 44481:1, 1 ex. (80.7 mm SL), syntype of Rhamdella ignobilis, Flusse Cubatão im Staate Santa Catharina bei Theresopolis (Brazilien) [Brazil, State of Santa Catarina, Rio Cubatão].

"Rhamdella" longipinnis: AMNH 8642, 1 ex. (88.0 mm SL), holotype of Rhamdella longipinnis, Prov. St. Paulo, Brazil [Brazil, State of São Paulo].

Rhamdella longiuscula: ILPLA 1353 [ex MCP 11211], 3 ex. (94.8-100.5 mm SL) and 1 ex. C \& S (106.2 mm SL), paratypes, Brazil, tributary of Rio Ibicuí, near São Leandro; MCP 12722, 82 ex. (13.9-133.8 mm SL) and 2 ex. C \& S (120.9-123.0 mm SL), paratypes, Brazil, State of Rio Grande do Sul, São Nicolau, Arroio Passo do Alto, próximo à localidade de Mineiral; MCP 17241, 5 ex. (18.1-31.3 mm SL), Brazil, State of Rio Grande do Sul, Rosário do Sul, Rio Ibicuí basin, affluent of Rio Ibirapuitã, before São Leandro; MZUSP 41067, 18 ex. (21.5-126.4 mm SL), Brazil, State of Rio Grande do Sul, distrito de Coimbra, Santo Ângelo, Rio Uruguai system, Rio Piratiní, fazenda dos Hinz.

Rhamdella rusbyi: CAS 63729, 2 ex. (164.4-168.2 mm SL) and 1 ex. C \& S (162.5 mm SL), paratypes, Bolivia, Río Colorado drainage, Lower Bopi; UMMZ 66317, 2 ex. (158.5-160.4 mm SL), paratypes, Bolivia, Beni-Amazon, Río Colorado, 10 miles above Huachi, tributary to Río Bopi; USNM 117603, 1 ex. (168.12 mm SL), paratype, Bolivia, Río Colorado, Lower Bopi; USNM 86829, 3 ex. (134.2-183.8 mm SL), paratypes, Bolivia, Río Colorado, Lower 
Bopi.

"Rhamdella" montana: FMNH 56067, 1 ex. (37.0 mm SL), holotype of Rhamdella montana, Peru, Queta, southeastern of Tarma.

Rhamdia foina: CAS 13468, 2 ex. (110.9-157.5 mm SL), Guyana, Warraputa cataract, Essequibo River basin.

Rhamdia laticauda: AMNH 24633, 4 ex. (53.6-77.4 mm SL) and 1 ex. C \& S (65.5 mm SL), Guatemala, Esquintla, in small sluggish stream, $1.6 \mathrm{~km}$ South of Obero, on dirt road from Iztapa to route CA9.

Rhamdia quelen: ILPLA 615, 1 ex. C \& S (64.0 mm SL), Argentina, San Nicolás, in delta of the Río Paraná; LIRP 100, 5 ex. (84.9-142.4 mm SL), Brasil, State of São Paulo, município de Cajuru, Rio Cubatão, Rio Pardo basin (21ํ2N 47²17’E); UFRJ 0321, 3 ex. C \& S (36.4-70.2 mm SL), Brazil, State of Minas Gerais, Ipatinga, Córrego Braúna, Rio Doce basin.

Rhamdioglanis frenatus: UFRJ 0322, 1 ex. C \& S (72.0 mm SL), Brazil, State of Rio de Janeiro, Rio Macaé, in confluence with Rio Sana; UFRJ 0504, 1 ex. C \& S (76.5 mm SL), Brazil, State of Rio de Janeiro, Rio Macacu, $52 \mathrm{~km}$ upstream from Cachoeiras de Macacu.

Rhamdiopsis microcephala: ZMUC 325, 1 ex. (77.5 mm SL), syntype of Rhamdia microcephala, Rio das Velhas, Brazil.

Rhamdiopsis moreirai: MCP 14513, 2 ex. (34.1-37.4 mm SL) and 1 ex. C \& S (39.3 mm SL), Brazil, State of Paraná, in stream tributary to Rio Negro (Rio Iguaçu basin), on road between Rio Preto do Sul/Rio Negro.

Taunayia bifasciata: MZUSP 35234, 29 ex. (50.4-114.7 mm SL), MZUSP 45903, 2 ex. C \& S (53.1-58.7 mm SL), Brazil, State of São Paulo, Santo André, last stream before Paranapiacaba, on dirt road Campo Grande/Paranapiacaba. 